\title{
AŞEZĂRI DIN EVUL MEDIU TIMPURIU LA VADU ANEI
}

Eugen S. Teodor.

În vara anului 1991 a început, cu un avânt bine mediatizat, construcţia autostrăzii Bucureşti-Constanţa. Cel mai important punct arheologic afectat de lucrări de construcţie, pe tronsonul București-Fundulea, a fost cel de la km. 12 al viitoarei autostrăzi, pe malul stâng al pârâului Pasărea, între pădurea Brăneşti şi satuł Vadu Anei. Deşi foarte bogată din punct de vedere arheologic, zona a fost destinată amplasării unei imense gropi de împrumut ${ }^{1}$. Atunci când au început cercetările pe teren (iulie 1991), lucrările de decapare erau demarate, fiind distrusă o suprafaţă de circa $6000 \mathrm{~m}^{2}$, zonă care figurează în planul general al sitului ca "Fosa autostrăzii". Având în vedere că secţiunile din marginea fosei autostrăzii (vezi planul de la Planşa I) au fost şi cele mai bogate, există prezumţia că zona distrusă fără să fi fost cercelată era şi cea mai interesantă.

Cercetarea propriu-zisă a început în august 1991 şi s-a încheiat în iulie 1993, cu înèeruperi numei în lunile de iarnă. Suprafaţa mare $\left(60000 \mathrm{~m}^{2}\right)$, lipsa mijloacelor mecanice specializate (miniaturizate) de decapare, absenta mijloacelor de cercetare de suprafată geofizice - faceau imposibilă o cercetare exhaustivă. De aceea s-a procedat, încă de la început, prịn trasarea unor secţiuni de sondaj, cu dezvoltăni în suprafaţă numai pentru obiective de maxim interes, cum a fost cazul necropolei medievale, care a fost cercetată aproape integral, dar şi în cazul unor obiective limitate (locuinte, obiective mesteșugrasti) atunci când tirnoul a permis. Au fost trasate 36 de secţiuni, la intervale relativ regulate, de lưrigime şi lătimi diferite, funcţje de obiectivele umărite, având sau nu casete pendinte, dar şi 26 de suprafeţe pentru degajarea spaţului necropplei (în chenar, la PI. 1). Aceste supıafețe nu figurează în planul general, care ar fi devenit ilizibil, la această scară, prin adăugarea atâtor detalii².

În ciuda eforturilor susţinute de doi ani, acoperirea sitului prin cercetare este destul de slabă. Au fost cercetaţi $4156 \mathrm{~m} 2$, ceea ce reprezintă 7\% din suprafaţă.

"Fosa autostrăzii" a împărḅit spaţul cercetat în două zone distıncte, ana de nord ("Sectorul A") şi una de sud ("Sectorul B"). Sectiunile sunt notate pe plan cu cifre romane (S.I, S.XIV etc.). Acolo unde secţunile au discontinuităţi (fie fiindcă trebuiau sărite obstacole, fie din alte motive), segmentele de sectiuni sant notatı: cu literă mică (de exemplu S.VII a, S.VII c). Casetele pendinte de o secţiune poartă indicativul secţiunii, la care se adaugă o literă majusculă (de ex. VII b C, XXIII B). Secţiunile care dublează o altă secţune pe o anumită distanţă au fost asimilate casetelor (de ex. DodIII C). Suprafeţele sunt notate cu o literă majusculă (de la A la Z). Aspectul topografic prezeniat în planul general este cel din inomentul execuţiei ridicării topografice (noiembrie 1991). Ulterior, "fosa autostrăzii" şi-a schimbat configuraţia, atât prin nivelare, cât mai ales prin lărgire, în special spre sud. O eventuală reluare a cercetărilor îşi va stabili ca punct de calcul piciorul podului peste lacul Pasărea $5^{3}$.

\footnotetext{
1 Conform unor legi prea bine cunoscute, şurubelniţ va fi scăpată din mână deasupra sticlăriei scumpe de laborator. La fel se intompla cu gropile de imprumut. Inexistenta unor forme institutgonalizate de colaborare intre proiectanţi și arheologi face ca proiectele de investiţi să nu tină seama de protecţia patrimoniului arheologic decát in prea mică măsură. Evident, o groapă de imprumut nu ar trebui sł fie amplasată intr-un sit arheologic, fiindcă acest fapt amplifică sarcinile arheologilor dincolo de posibiliţ̧̧̧̧le de execưţie, indiferent de nivelul finanţării.

2 Planul necropolei, inclusiv suprafețele de cercetare, va fi publicat, fără indoială (fiindcă există), in monografia aşezării de secol XVI, care sper că nu va mai întórzia să apară.

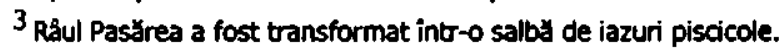


Punctul arheologic de la km.12 a fost numit în rapoartele de săpătură "Brăneşti-Vadu Anei", după numele comunei în raza căreia se află, cât şi după numele cătunului aflat la circa 500 de metri spre sud. După mărturia localnicilor, punctul se numeşte "Călugărul"; cercetarea arheologică nu a putut însă oferi o explicaţie pentru acest toponim. Numele firesc al sitului este însă, conform uzanţelor, cel al localităţii celei mai apropiate: Vaciu Anei (sat aparţinând comunei Brăneşti, judeţul Ilfov, fost SAI).

Descoperirile se întind din neolitic până în secolul al XVIII-lea, la sfârşitul evului mediu românesc. Epocile cele mai bine reprezentate sunt perioada dacită clasică, evul mediu (în special secolul al XVI-lea) şi evul mediu timpuriu, cu două etape distincte de locuire.

Cercetarea sitului de la Vadu Anei a fost încredintată unui numeros colectiv de la Muzeul National de Istorie a României. Am să amintesc aici numai pe cei care s-a întâmplat să descopere şi să investigheze obiective ale evului mediu timpuriu: Paul Damian (care a fost şi responsabilul de contract cu Administraţia Naţonală a Drumurilor), Anca Păunescu (coordonatorul știinţific al săpăturilor) şi semnatarul acestor rânduri (care a răspuns şi el de ceva, respectiv evidenţa topograrică).

Descoperirile privind evul mediu timpuriu vizează două perioade distincte: primul sfert al secolului al VII-lea şi secolele X- începutul secolului XI. Ambele aşezări, aşa cum rezultă din repartiţia complexelor, dar şi a fragmentelor ceramice pe nivel (vezi plarıul general, la planşa 1), se înşirau în stânga râului Pasărea, pe o fâşie lată de maxim $\mathbf{5 0}$ de metri, nu mai aproape de $\mathbf{5 0}$ de metri de marginea terasei (unde panta este inai accentuată), într-o poziţie relativ adăpostită, sub nivelul câmpiei de la NE. Lungimea şi densitatea aşezării de secol VII este mai mică - 4 complexe la 200 de metri liniari (1 hectar). În ce priveşte aşezarea de epocă Dridu, a fost constatată, prin săpătură, pe 0 lungime de 300 de metri, însă perlegheza a semnalat o nelndoiefnică continuitate până la marginea satului Vadu Anei (încă cel puţin 500 de metri spre sud). Densitatea este de 12 complexe la 1,5 ha., suprafaţa estimată a satului fiind de minim 3 ha.. Malul opus al râului, mult mai abrupt, dar şi mai expus Crivătului, este steril arheologic (cu excepția unor cioburi răzleţe de epoca bronzului), insă la circa $1 \mathrm{~km}$. spre sud, în aval, a fost semnalată o altă aşezare (?) dridoidă.

\section{AŞEZAREA DE SECOL VII. DESCRIEREA COMPLEXELOR}

S-au descoperit patru complexe, respectiv trei locuinţe şi un cuptor. Dispunerea lor pe planul general este următoarea: L. 1 şi C. $1^{4}$ în sectorul $A$ (nord) şi L. 2 şi L. 3 în sectorul $B$ (sud). Dacă cele din urmă vor fi de găsit marcate convenţional, pe S. XXIV b şi pe S.XXVIII a, celelalte complexe se aflæ în suprafeţe neindicate în planul general: L. 1 se află în suprafaţa $T$, la capătul de N al S.XVIII, iar C. I la SV de S.XIX (mai aproape de secţiune decât s-a putut marca).

Locuinţele nu au putut fi săpate integral din motive obiective, fiind însă cercetate cuptoarele şi putând fi trase minime concluzii asupra tipului de locuinţă. Baza comparativă este cu siguranţă prea mică pentru a putea vorbi de un tip generic. Pentru a economisi însă descrierile lungi şi repetitive, voi enuntạ întâi un ipotetic tip generic, arătând apoi diferenţele specifice, cât şi problemele.

Locuintele sunt de tip semi-îngropat (mai exact: parţia/ semi-îngropat), groapa coborând de la baza nivelului medieval (negru-cenuşos) - sau a nivelului Dridu, unde există - între 60 şi 70 de cm.,

\footnotetext{
4 Nomerotarea de publicare nu coincide cu cea de şantier. Şantierul, find de dimensiuni mari, ar fi fost nepractic să funcționeze cu nomerotare unică. Din ratiuni practice, nomerotarea complexelor s-a facut independent, pentru fiecare sectjune. Sistemul ar putea fi insă greoi şi confuz pentru cititor. Colectivul a hotărát, pentru publicare, renomerotarea complexelor pentru fiecare epocă.
} 
aproape vertical. Nu se pot constata amenajări ale pereţilor sau ale podelei. Dimensiunile, cât au putut fi abservate, variază destul de mult, de la o lăţime de numai 1,9 m. (t. 3, Planşa 3/a) la 2,9m., cât măsoară, la maxim, L. 2 (PI. 2/c), sau până la 4,5 m. latura cercetată integral la L. 1.(PI. 2/a). Aceasta din urmă dimensiune se explică prin surparea pereţilor care se învecinează cu cujptorul, fapt care a obligat la o corectare - prin lărgire - a gropii locuinţei, şi a condus probabil la adoptarea soluţiei constructive cu pari înfipţi în interiorul gropii sau la colţurile acestuia, pe exterior, soluţie necunoscută pentru gropile de locuinţă de dimensiuni mici.

Cuptoarele sunt săpate în lut, parţiel în perimetrul gropii locuinţei (în calup cruţat), parte în afară acestui perimetru, fie pe latura de NE (L. 2 şi L. 3), fie pe aceeaşi latură, spre colţul de E (L. 1). Toate cuptoarele au, deasupra calotei scobite, un "hom" inălţat cu lut adăugat. Tipul constructiv poate fi enunţat foarte exact, starea de conservare a cuptoralui din L. 3 fiind excelentă, chiar dacă cuptorul a fost găsit secționat, longitudinal, de un alt complex. Cuptorul din L. 2, deşi cu partea frontală a homului prăbuşită, sugerează acelaşi tip constructiv, în ciuda diferenţelor substanţiale ale planului.

Cuptosul din L. 1, ca şi locuinţa, a fost refăcut, pereţii fiind în întregime îuălţaţi din lut, însă strădania de a respecta acelaşi tip este evidentă, pereţii groşi schiţând întâi o boltire, ridicând apoi un horn răsfrânt spre afară (PL. 2/b). În toate cazurile, vatra coboară 10-15 cm. dinspre spate spre gură. Vatra, lututtă simplu, are o formă greu definibilă, apropiată tipului "potcoavă", uneori asiznetrică. Dimensiunile variază de la 0,72 (pe axul gurii) $/ 0,52 \mathrm{~cm}$. (L. 2), la 0,76/1,00 m. (L. 3 - ultima dimensiune fiind probabila).

Despre orientareł locuintelor este mai greu de discutat, în absenţa unei săpătur complete. Ar fi totuşi de spus că întotdeauna o latură este spre NE, că întotdeauna acolo se află cuptorul, care are mereu aceeaşi orlentare, cu spatele spre NE, presupunând o intrare în locuinţă pe peretele de SV. Nu au fost surprinse nici un fel de amenajări de acces (gârlici, trepte sau urme ale scării de lemn).

Inventaru/este sărac, reducându-se la fragmente ceramice, vălătuci elicoidali sau cilindrici şi zgure metalice (în fiecare complex, dar în cantităţi mici), un fragment de tavă fixă (în L. 3). Atât cât este, inventarul se află pe o poliţă amenajată în spatele cuptorului, la nivelul hornului, adică 50 de $\mathrm{cm}$. mai sus decât podeaua şi cca. $10 \mathrm{~cm}$. mai jos decât propriul nivel de călcare, la exterior (PL. 2/c profilul nordic al S.XXIV a). Inventarul mai poate fi găsit pe vatră, probabil căzut de pe poliţă, dar e aproape absent în restul gropii loculintei.

Inventarul sărac şi neîntregibil sugerează că locuirea a fost părăsită paşnic şi fără grabă.

Problemele sunt legate de dimensiunile şi forma locuinţelor, sau chiar de atribuirea culturală.

În ce priveşte $L$. 3, nu-i cunoaştem întinderea către NV (săpătura fiind imposibil de extins în acea direcţie) ${ }^{5}$, iar latura de SE este tăiată de L. 8 (Dridu); situaţia cuptorului din L. 8 ne permite însă să presupunem că groapa Locuinţei 3 avea cel puţin încă $1 \mathrm{~m}$. spre SE. Atât cât se poate vedea în plan (PI. 3/a), forma gropii este arcuită, "pliată" pe cuptor; formă care nu e dintre cele obişıuite şi care ar putea să pară ciudată, nu însă şi dacă admitem că forma şi mărimea locuinţei nu coincid cu groapa locuinţei. Etnografia recomandă locul din spatele cuptorului ca fiind preferat pentru odihnă. Arheologic, situaţia concretă este aceea că în spetele cuptoarelor din L. 2 şi din L. 3 era amenejată polița pe care stăteau oalele, trebuind să accedem că locul respectiv nu putea fi exterior locuinţei.

\footnotetext{
${ }^{5}$ La ora la care complexul era cercetat, S. XXVIII devenise un fel de linie a frontului. Constructorii lărgeau "fosa autostrăzli" și, dintr-un motiv care îni scapă, puseseră grămezi uriaşe de pământ în spatele secţunii. L. 3 a fost urmărită prin săpătură atŝt căt a fost posibil.
} 
Întrebarea daca locul din spatele cuptorului putea servi şi de "bufet" şi de dormitor este foarte bună, chiar dacă deocamdată nu i se poate răspunde întrebarea sugerează însă că locul respectiv ar trebui să fie destul de spaţios.

În concluzie, spaţiul locuit nu coincide cu groapa locuinţei, fiind mai mare şi putând să ia oricare altă formă6 0 groapă semilunară pliată pe cuptor - având funcţia de groapă de acces la cuptor - nu exclude fireasca formă rectangulară a planului locuinței.

Locuinţa 1 ridică chiar o problemă de atribuire, întrucât este complet lipsită de inventar. Cele câteva sfărâmături de cioburi sunt atipice, putând fi la fel de bine din perioada dacică. Situaţia sar putea explica atât prin faptul că partea superioară a gropii locuinței este perforată de mai multe monninte de secol XVI, de o altă groapă mare - tot medievală, cât şi prin absenţa poliţei pe care se găsea obişnuit inventarul. Atribuirea complexului secolului al VII-lea s-a facut, ipotetic, numai pe baza sinonimiilor de construcţie a cuptorului, cât şi a locuintei, în faza I.

O situație particulară prezifłă cuptorul (C. 1), care a suferit o dublă distrugere înainte de descoperire, îngreunând înţelegerea contextului arheologic. Prima distrugere s-a produs în secolul al XVIlea, când un mormânt din extremitatea sud-vestică a cimitirului (M.161, cu gambele în S.XIX) a dărâmat pereţi cuptorului până la $10 \mathrm{~cm}$. de vată. A doua distrugere s-a petrecut la 6 martie 1992, când un buldozer a distrus partea respectivă a necropolei, inclusiv partea din peretele cuptonului care probabil mai existase, cât şi eventualele indicaţii de context. Din scheletul 161 rămăseseră in situ câteva coaste şi antebraţele (fiind recuperată totuşi o monedă). Ridicând oasele, am avut surpriza să găsim, în strâmtul interval până la vatŭ̆, un destul de bogat material ceramic - indusiv două borcane mici întregibile (singurele, de altfel. ...) - şi vălătuci, adică inventanul obişnuit cuptoarelor din locuinte. Similitudinea s-a confirmat prin orientare şi prin acea caracteristică a vetrei de a coborî $10 \mathrm{~cm}$. pe axul longitudinal, spre gură. Alte date comparative neexistând, am căutat oricare alt indiciu că C. 1 era de fapt o componentă a unei locuinţe; distrugerea provocată de lama buldozerului era însă prea adâncă pentru a mai fumiza cel mai mic iodiciu in favoarea sau in defavoarea ipotezei. Am concluzionat, totusi, ca a vorha de coptorul unei locuinte 7 , fiind puţin plauzibil ca un astfel de inventer să aparţină unui cuptor în aer liber (care ar fi trebuit să fie, teoretic, un cuptor de pâine). Notaţia a rămas însă, firește, cu sigla C ("cuptor").

\section{CERAMICA ASEzǍrII dE SECOL VII.}

Starea fragmentară a ceramicii nu permite stabilirea numărului total de vase de la care provin fragmentele ceramice, ci doar o aproximare. În toate cele trei complexe care au inventar (C. 1 , L. 2 şi L. 3) s-au găsit fragmente de la 10 până la 15 de recipiente, majoritatea fragmentelor fiind mici. De aceea, am alcătuit un tabel cu situația statistică a principalelor caracteristici, raportată la numărul de fragmente ceramice şi nu la numărul de vase, cum ar fi fost de dorit (infra).

\footnotetext{
6 Alte argumente in acest sens la I. MTREA, MemAntiq, XIX, 1994, p. 289-293.

7 Inventarul locuinţelor se găseşte aproape întotdeauna, în sau pe cuptor, cel puţin in Muntenia: v. LEAHU, CAB, I, 1962, p. 38; S. DOLNESCU-FERCHE, Asezări din sec. III și $V$ e.n. in sud-estul Munteniei. Cercetärile de la Dulceanca, Bucureşti, 1974, p. 63 şi următoarele; M. CONSTANTINIU, CAB, II, 1965; M.CONSTANTINIU, SCIV, XVI, 1966, 4, p. 668, care enumeră mai multe situri cu această caracteristică, cu bibliografia aferenta.
} 


\begin{tabular}{|c|c|c|c|c|}
\hline $\begin{array}{c}\text { COMPLEXUL } \\
\text { CRTERIUL }\end{array}$ & C. 1 & L. 2 & L. 3 & Medie total \\
\hline $\begin{array}{c}\text { PASTA (\%) } \\
\text { cu nisip }\end{array}$ & 92 & 100 & 62 & 85 \\
\hline cu pietriş & 75 & 28 & 38 & 47 \\
\hline cu cioburi pisate & 50 & 57 & 61 & \\
\hline cu vegetale & 16 & 7 & 23 & 15 \\
\hline cu ocru & 33 & 3 & 0 & 12 \\
\hline baie de lut & 33 & 18 & 0 & 17 \\
\hline $\begin{array}{c}\text { ARDERE (\%) } \\
\text { bună }\end{array}$ & 75 & 36 & 0 & 37 \\
\hline bună dar Inegală & 25 & 36 & 23 & 28 \\
\hline incompletă & 0 & 28 & 77 & 35 \\
\hline $\begin{array}{c}\text { CULOARE } \\
\text { gălbui- } \\
\text { roşcat }\end{array}$ & $\begin{array}{c}\text { gălbui-roşcat } \\
\text { (-albiclos) }\end{array}$ & $\begin{array}{c}\text { gălbui-roşcat } \\
\text { (-cenușiu) }\end{array}$ & $\begin{array}{c}\text { (gălbui- } \\
\text { roşcat) }\end{array}$ \\
\hline $\begin{array}{c}\text { LUCRAT LA ROATX LENTX } \\
\text { (\%) }\end{array}$ & 0 & 0 & 3 & 1 \\
\hline
\end{tabular}

Rezultatele sunt interesante, evidenţiindu-se un vector (cronologic?) C. $1>$ L. $2>$ L. 3, cu următoarele evoluţii: pasta care conţine şi cioburi pisate (alături de alţi ingredienţi, ca microprundişuri) este dominantă şi din ce în ce mai caracteristică; dispare baia de lut dinaintea arderii (obişnuită în secolul al VI-lea, mai ales în vestul Munteniei) ${ }^{8}$; se renunţ̌̆, de asemeni, la adăugarea de ocru rosu în pastă; calitatea coacerii vaselor diminuează sever ${ }^{9}$. Menţionez că prezenţa cioburilor pisate în pastă este discretă, cioburile fiind bine mărunţite şi relativ puţine; practic - greu de observat. Această caracteristică circumscrie, totuşi, situl de la Vadu Anei în aria răsăriteană a culturii IpoteştiCiurel-Cândești10. E de remarcat, însă, că această specie de pastă nu lipsește în siturile din bazinul inferior al Dâmbovitei, fiind de găsit la Ciurel, însă mai sporadic (după cum rezultă din raport). Având în vedere că între situl de la Ciurel (cu exceptia locuinţei B.1B) şi cel de la Vadu Anei se interpun, probabil, două generaţii, între prezenţa sporadică a speciei la Ciurel şi vectorul ascendent de la Vadu Anei s-ar putea imagina o posibilă legătură. Astfel de legături vestice sunt relevate şi de baia de lut, care caracterizează în primul rând aria Ipotești.

B. 1B de la Ciurel pare să reprezinte veriga cronologică şi culturală imediat următoare sitului de la Vadu Anei, cu ceramică lucrată la roată lentă, cu vase de provizii lucrate cu mâna și cu tăviţe cu pastă conţinând cioburi pisate.

Mai vechea aserţiune că ceramica lucrată la roată lentă se generalizează începând cu al doilea şi al treilea sfert al sec. al VII-lea este confirmată de săpăturile mai noi, procesul apărând încheiat la Dulceanca IV 11 , în ultimul sfert al aceluiaşi secol, câno cultura Dridu este deja configurată, in aspectele ei esenţiale.

\footnotetext{
8 DOUNESCU-FERCHE, ...Dulceanca, 1974, p. 90-95; M.CONSTANTINIU, SCTV, XVI, 1966, 4, p. 673, unde se arata cr aceasta practică apare în secolul al VI-lea și este o influenţ̆ bizantină.

${ }^{9}$ Fenomenul Caracterizeazä evoluja afturii amintite, fiind dar definit la Budureasca, sit a carej stratigrafie a permis surprinderea unor secvente coonologice (V. TEODORESCU, Sesiunea de comuničri știinthifice a Muzeelor de Istorie, dec. 1964, voL. II, Buc., 1971).

10 ibidem; S. DOUNESCU-ÆERCHE, Dacia N.S., DOCII, 1979, p. 222-224.

11 S. DOLINESCU-FRCHE, Dadia N.S., XOXM, 1992.
} 
Aceiaşi locuinţă B. 1B de la Ciurel prezintă analogii morfologice apropiate cu ceramica de la Vadu Anei, atât cu unicui fragment lacrat pe roată lentă, cât şi cu ceramica lucrată cie mână. Cunoscând idiosincrazille conexe acestui gen de comparaţii12 şi utilizând o bază de date şi o metodologie deja funcţionale ${ }^{13}$, am aplicat măsurătorile lotului ceramic desenat de la Vadu Anei (care nu este complet, dar e reprezentativ), rezultatele fiind transcrise în tabelul de la PI. 13. Restul cifrelor din acest tabel nu poate fi explicat în spaţiul acestei expuneri, el putând fi evidenţiat numai prin consultarea lucrării speciale. Aici poate fi pusă în evidenţă doar concluzia analizei pe care cifrele au îngåduit-o, surprinzătoare chiar şi pentru uutorul acestor rânduri: una dintre cele mai apropiate analogii ale ceramicii de secol VII de la Vadu Anei o constituie ceramica lucrată cu mâna din cimitirul de la Noşlac (jud. Alba) ${ }^{14}$. Analogia formală merge până la detalii, cu excepţia proporţei diametrului bazei, care este mai mare la Vadu Anei, crea ce particularizează situl în tot contextul epocii. Acestea au fost doar nişte exemple, fiindcă analogiile ceramice sunt mai numeroase şi va trebui să revenim.

\section{CONCLUZII PRIVIND AŞEZAREA DE LA ÎNCEPUTUL SECOLLLUI AL VII-LEA.}

Suprafata pe care se întindea așezarea de secol VI a fost săpată în proporțe de o pătrime, în limitele timpului disponibil. Deşi săpată - şi, deci, cunoscută parţ̧ial - aşezarea se încadrează din multe puncte de vedere in normele perioadei istorice și a microregiunii. Este vorba de o aşezare de terasă, în apropierea apei (râul Pasărea), răsleţită, de mică durată (fără nivel arheologic observabil), în consecinţă fără gropi menajere surprinse ${ }^{15}$, deşi spaţul dintre C. 1 şi L. 1 a fost săpat integral, pentru cercetarea necropolei de secol XVI. Cunoscând dimensiunile aşezării, numărul de complexe (4) şi proporţia în care aşezarea a fost cercetată prin săpătură (25\%), aşezarea poate să fi avut 12 sau 16 locuinţe (a doua cifră în situatja în care încadrarea culturală a L. 1 este corectă), ceea ce pare să excludă varianta mai multor faze de locuire (aşezări de numai şase locuinte nu sunt cunoscute). Astfel, diferenţele dintre caracteristicile inventarului ceramic din C. 1 şi L. 3 reflectă variabilitatea practicilor meștesugarești în interiorul unei comunităţi şi nu diferenţe culturale. Diferenţele constatate in prepararea pastei reflectă tendinţele de deteriorare a condiţiei tehnice a produselor locale, fenomen care s-a tot accentuat în ultimele secole. Pe de altă parte, tocmai în L. 3 a apărut fragmentul de oală lucrată pe roată lentă, cea care se va generaliza, probabil începând chiar din generaţia umătoare; faptul confirmă constatarea că inventarul acestui complex este cel mai primitiv, dar şi cel mai evoluat (în situaţ̧a dată - nu este o contradicțe).

Locuinţele sunt de tip semi-adâncit, cu colţuri rotunjite, de obicei fără gropi de par observabile în interiorul gropii locuinţei. Nu au fost sesizate nici un fel de amenajări ale podelei şi

\footnotetext{
12 Doar penturu a exemplific: "Findeă nu e posibilă transmiterea dints-o ceramică în alta [= ceramică lucrată la roată rapidă - roata lentă] a unor elemente de dejor fară a se transmite inssi tehnlo de exeabie a vaselor, trza consemnată mai sus [transformarea tipului ceramic

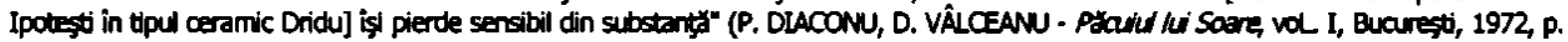
124). Copierea unei forme (sau decor) pe un up ceramic inferior ( $\sigma$ tehnich, pasta, ardere) este in general un fapt acceptat (de ex. V. TEODORESCU, MCAXVI, 1993, p. 368), ceea ce nul împiedič̆ pe acelaşi autor să lnfereze: "Concomitent au pastrarea formelor ceramice de origine dacica, era absolut nomal st' se transmitu (...) și tehnica de realizare a vaselor, din lut amestecat a cioburi pisate" (idem, p. 381), argument care este identic, in esentă, cu primul pe care l-am citat Conditionarea forme - care este in ultimă instantă un fenomen de proiectie a unui arhelip mental asupra materiej modelabile - de mijloacele materiale de exeagje nu se sustine, fiindca orice proiect (forma, decor) se poate realiza ple materiale și ou tehnid diferite.

13 Eugen S. TEODOR - Sistemul Compas. Studiu de morrologie analitica numerica, aplicat ceramicii urvale din perioada de migrafie a slavilor, Bucuresti 1996.

14 M. RUSU, Dacia N.S., VI, 1962, fig. 5/4,5; 7/4,8.

15 Aşezárile de scurta durată se caracterizează prin raritatea gropilor menajere, fapt adeseori atestat in epocă (M. CONSTANTINIU, SCTV, 1966, 4, p. 668).
} 
pereţilor $^{16}$. Cuptoarele sunt realizate pe latura de NE, prin scobire (sau cotlonire) în lut ${ }^{17}$, parţial în calup cruţat - parţial în afara perimetrului gropii; indiciu că spaţiul locuit nu se reduce la groapa săpată. Cuptoarele erau prevăzute cu "horn", adăugat din lut purtat ${ }^{18}$, horn astupat, la nevoie, cu aşa numitele "tăvi portative" 19 , de fapt cât se poate de fixe.

Inventarul este sărac şi fragmentăr, semn că așezarea a fost părăsită paşnic şi fără grabă, şi se reduce la ceramică lucrată de mână (cu excepţia din L. 3), vălătuci, fragmente de la o "tavă portativă" şi zgură (dar fară obiecte de fier). Practic tot inventarul a fost găsit pe platforma din spatele cuptorului sau pe vatra cuptorului.

Tot ce am enumerat până aici se înscrie într-o perfectă normalitate pentru câmpia norddunăreană. Surprinde însă absenţa tipsiilor (numite şi tigăi, tigăiţe), atât de caracteristice epocii, prezente peste tot în microzonă, fie şi în cantităţi reduse ${ }^{20}$. 0 altă anomalie, cel puţin aparent, este reprezentată de ceramică, fiind lucrată aproape exclusiv de mână. Chiar şi pentru Moldova, unde ceramica lucrată de mână reprezintă o dominantă, din secolul $V$ în secolul IX, 0 asemenea situație ar fi oarecum inedită ${ }^{21}$. Nici pentru Transilvania complexele cu ceramică exclusiv lucrată de mână nu sunt ceva obişnuit. De curând a fost comunicată însă descoperirea unor locuinţe, datate în secolul al VII-lea, având relativ multă ceramică, exclusiv lucrată de mână22, pe care am văzut-o şi care, cel puţin aparent, este destul de asemănătoare celei de la Vadu Anei.

O asemenea încheiere ar putea sugera ideea unei migraţii, de care epoca nu a dus lipsă, în sprijin vemind câteva locuri comune: ceramica de mână este lucrată de noii veniţi - slavii, iar tehnica lutului amestecat cu cioburi pisate aparţine aceloraşi. Aceste prejudecăţi, fireşti la nivelul cunoştinţelor anilor '50-'60, sunt astăzi dovedit depăşite. Fără a putea face aici o dezbatere reală a problemelor, voi aminti doar câteva argumente: dualismul tehnic ceramică lucrată la roată / lucrată de mână defineşte La Téne-ul autohton, ceramica rudimentară nefiind niciodată complet abandonată în antichitatea târzie ${ }^{23}$, nici măcar în Dobrogea îndelung romanizatła $24 ;$ tendinţa majorării procentului tehnicii de

\footnotetext{
${ }^{16}$ Toate caracteristicile enumerate ale locuintei sunt frecvente in Muntenia şi Moldova (vezi, de exemplu, S. DOUNESCU-FERCHE, ...oulceanca, 1974, p. 63-89; V. LEAHU, CAB, I 1962; I. MIREA, MemAntiq, XXX, 1994, p. 281-315; P. ROMAN - S. FERCHE, SCINA., 29, 1978, 1, p. 87; I. MITREA, MCA, XV, 1983.

17 Instalaţie de foc dominanta, in epoca, oriunde subsolul este lutos (MITREA, XV, 1983; P. ROMAN - S. DOUNESCU FERCHE, SCINA., 29, 1978, 1, p. 87; M. CONSTANTINIU, CAB, II, 1965, p. 167; S. DOUNESCU-FERCHE, Dacia N.S., XOII, 1979, p. 185200, 222; idem, .... Du/ceanca, 1974, p. 63-89; V. LEAHU, CAB, I, 1962.

18 Un tip asemănător se cunoaşte pentru secolul at III-lea (S. DOUNESCU-FERCHE, ...Dulceanca, 1974, p. 23 şi urm., B.III); pentus secolul al VI-lea poate fi mentionat la Radovanu, CSmpul lui Boja, Bucurestii Noi, Stròulesti-Lunca, Băneasa-Străuleşti (M. COMŞA, Muzeul Naţonal, II, 1975); Băneasa - "La Stejar" (M. CONSTANTINIU, CAB, II, 1965); Vasilica SANDU - "Aşezarea de la Bălăceanca, S.A.I.", comunicări la Sesiunile naţionale de rapoarte din 1993-1995, cu mai multe exemplare.

19 Acestea apar asociate totdeauna tipului de cuptor cu "horn", fiind legate functional.

20 Textul raportului are deja o vechime de dira 5 ani, iar o serie de fapte ar primi astăzi o altă explicatie sau cel putin o altă nuanţ. Pentru chestiunea tövityelor "slave" vezi un studiu monografic in curs de aparitje în Istro-Pontica "Cerarrico de la Dulceanca"). Consideránd că, aid, important este ce se raportează şi nu ce se interpretează, nu am mai intervenit asupra textului.

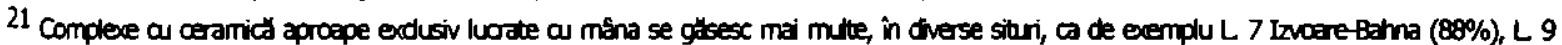

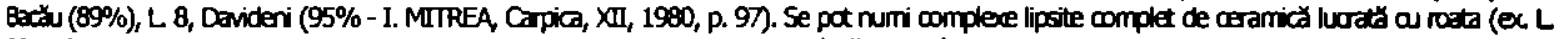

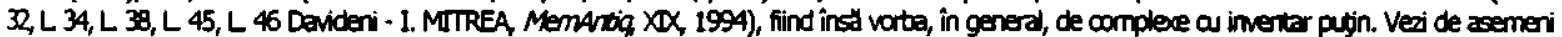
M. MATE, SCV, X, 2, 1959, p. 410-412, punctu SYpot, unde, in ouda celor 40 de fragmente, nu s-a inregistrat nio un fel de decor. Spre deosebire de

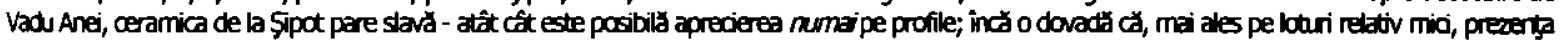

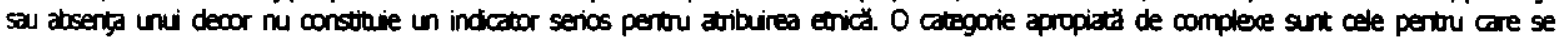

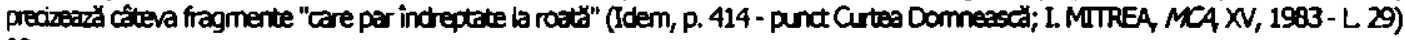

22 Ioan STANCIU, "Aşezarea de la Lazuri", jud. Sabu Mare, comunicare la a XOIX-a Sesiune nabjonală de rapoarte arheologice", Cluj-Napoca 1995. O descoperire asemănătoare a comunicat colega Gabriela Rădulescu, pentru proximitatea oraşului Bistriţ.

${ }^{23}$ V. TEODORESCU şi colab, MCA, XVI, 1993, p. 385.
} 
factură primitivă se constată încă din secolul V (faza Cireşanu II), odată cu deprecierea progresivă a ceramicii lucrată la roată. Fenomenul cvasi-generalizării ceramicii primitive la începutul secolului al VII-lea nu este legat excusiv de migraţia slavă, ci, într-un context cronologic, militar şi cultural mai larg, de toate migraţiile care au succedat culturii Sântana-Cerneahov.

Cioburile pisate în pastă caracterizează, într-adevăr, cultura materială slavă (cu excepția ariei culturale vestice). Dar acelaşi tip de pastă ceramică este atestat în cultura materială autohtonă (e. g. ceramica lucrată cu mâna de la Târgşor 25 , Cimitirul 1 Bratei ${ }^{26}$, Cireşanu ${ }^{27}$ ), pentru cele două secole care preced marile mişcări de populaţie slavă în bazinul Dunării de Jos. Mai mult decât atât, acest tip de pastă este folosit uneori pentru ceramica lucrată pe roată28, în situri din secolele IV-V. Or, aşa cum majoritatea cercetătorilor români o afirmă, primul val slav semnificativ care a deversat în Câmpia cie la Dunărea de Jos se datează în a doua jumătate a secolului al VI-lea ${ }^{29}$, când sunt pentru prima oară atestaţi în mod explicit ca locuind acolo. În fine, această populație nou venită, fáră deprinderea utilizării roţii de olărit, nu poate fi bănuită de a fi produs această ceramică. Este de discutat, în schimb, în ce măsură slavii au contribuit la amplificarea utilizării acestei tehnici ${ }^{30}$, dar nu se poate deduce o prezentă slavă la simpla constatare a fenomenului. Lucrurile stau asemănător în ce priveste prezenţa tipsiilor, obiecte atestate în locuri foarte diferite din Europa, pentru care problema prezentei slave nu se pune, 6 a de pildă Elveţa sau Anglia 31 , sau a alveolelor pe buza vaselor ${ }^{32}$, sau a tipului de locuinţă. Toţi acești factori pot da unele sugestii, dar nu soluţii. În cazul concret pe care îl studiem, este simptomatică absenţa tipsiilor şi a alveolelor pe buza vaselor, indicatori extrem de specifici în siturile stave

Această maximă barbarizare a culturii materiale a populaţiei autohtone poate fi datată, cu argumente arheologice şi istorice, la începutul secolului al VII-lea, când prăbuşirea limes-ului dunărean a condus la deplasarea unor mari mase barbare spre inima Balcanilor, generând un climat de maximă instabilitate şi prăbuşirea comerţului (la Vadu Anei importurile lipsesc cu desăvârşire). Pria această prismă, toate caracteristicile enunţate ale sitului de la Vadu Anei devin firești. Primele decenii ale veacului VII constituie, fără îndoială, perigeul societăţii carpato-dunărene în ceea ce s-a numit, nu fără temei, "Mileniul întunecat".

\footnotetext{
24 C. SCORPAN, Pontica, III, 1970 - unde se găseste o amplă sinteză a probłemei. Prin bunăvoinţa colegului Ioan C. Opriş am văzut un lot masiv de oale lucrate cu måna, provenind din corpul de gardă de la Capidava, alături de numeroase piese de factură romană, dintr-un orizont de distrugere databil destul cert la 559.

25 Gh. DIACONU, Despre ceramica dacică din necropola de la Tárgsor, lucrata cu mâna, în Omagiu lui P.Constantinescu-Jaşi, Bucureşti 1965, p. 117, pentru sfârşitul sec. al III şi începutul sec al IV-lea.

26 L. BÂRZU, Continuitatea populatiei autohtone in Transilvania, in secolele IV-V (Cimitinul 1 de la Bratei), Bucureşt, 1973, p. 43, pentru a doua jumattate a sec. al IV-lea şi inceputul sec. al V-lea., ceramiça lucrată cu mána.

27 V. TEODORESCU şi colab.., MCA, XVII, 1993, p. 397, pentu sfârşitul sec. al IV-lea şi secolul V, ceramică lucrată la roată şi ceramică lucrată de mână.

28 M. CONSTANTINIU, SCIA, XVII, 1966, 2, p. 669, nota 2; V. TEODORESCU şi colab., MCA, 1993, p. 397.

29 FHOR, II, Menander Protector, 48, unde este descrisă campania avară de pedepsire din 579 impotriva słlaşurilor slave, localizate explicit în cámpia nord-dunăreană şi care este prima menţiune a unor aşezd̆ri slave in acest areal geografic. Prezenţ slavă poate cobori, odată cu datarea necropolei de la Sărata Monteoru, pánă la jumătatea secolului al VI-lea (AN. MAOGEARU Continuitote şi discontinuitate..., Buc. 1997, p. 121.)

30 İ bazinul mijlociu at Siretului circa $70 \%$ dintre vase au această reţetă tehnologič.

31 W. HÜBENER, Absotzgebiete frigeschidtiticher Topferein in der Zone Nördiloh der Alpen. Beiträge zur Keramik der Merowingzeit, Bonn, 1969, fig. 179/4; L LAING, The Arohaedogy of Late Cetbic Eitain and Ireland C.400-1200 A.D., London, f.a., fig 93/4, 5. Multumesc pe aceasta cale d-lui Dan Gh. Teodor, care mi-a atras acentija asupra aspectului şi mi-a pus la dispożtje bibliografia.

32 Şi acest motiv decorativ, prezent mai des in varianta töieturilor şi impresiunilor pe buž, are aceeaşi notabilă extensie geografică, în insulele britanice părând a fi destul de frecvent (L. LAING, The Archaeology..., fig. 92/5; 93/2 ,4; 94/2)
} 
Cercetările de la sfârşitul anilor 80 şi începutul anilor 90 au modificat peisajul arheologic cunoscut, după 1993 fiind publicate alte două situri33, dintr-un areal geografic proxim, ale căror caracteristici generale le apropie de situl de la Vadu Anei. Interpretarea acestor situri poate fi un aport semnificativ la înţelegerea fazei finale de evoluţie a culturii Ipoteşti-Cândeşti. Fiindcă fenomenul despre care vorbirn trebuie să poarte un nume, vom denumi această situaţie principial nouă - aspectul cultural Vadu Anei. Descifrarea rolului jucat de migratori în configurarea acestui aspect cultural necesită un studiu special, care sper că va putea fi publicat curând.

\section{AŞEZAREA APARTINÂND CULTURII DRIDU34. GENERALTTĂTI.}

Așa cum am mai spus, această aşezare este întinsă pe o suprafaţă mai mare, fiind descoperite complexe mai multe şi de factură diversificată, desâşurate pe o perioadă mai mare. Au fost descoperite, complet sau parţial, şapte locuinte, trei cuptoare - din care unul metalurgic - şi trei gropi menajere. Pentru a evita confuziile, nomerotarea complexelor s-a fácut în continuarea celor de secol VI; astfel, locuintele sunt notate de la L. 4 la L. 10, cuptoarele de la C. 2 la C. 4, iar gropile au sigle de la G. 1 la G. 3.

\section{DESCRIEREA COMPLEXELOR. LOCUINTELE.}

Cu excepţia locuinţei 5, celelalte se încadrează tịpului semi-îngropat, în multe asemănătoare celor descrise pentru secolul al VII-lea. Locuinţele 4, 6, 7 şi 8 au fost săpate practic complet (lipsind parţi mici din groapa "bordeiului"), în timp ce L. 9 şi L. 10 au fost numai semnalate, fiind prinse în secţiune numai câte o latură, săpătura neputând fi continuată în direcţia respectivă (aflându-se pe acelaşi S. XXVIII, situaţia comentată anterior când m-am referit la L. 3).

Gropile locuintelor sunt rectangulare, dacă nu luăm în considerare colţul în care se affă cuptorul ("colţ cruţat"), uneori cu o formă destul de neregulată (L. 6), cu laturile încheiate mai mult sau mai puţin rotunjit, cu variaţii notabile la una și aceeaşi locuinţ̌. Dimensiunile variază de la 3,40/3,30 m. (L. 4 - PI. 3/d) la 2,37/2,45/2,94/2,52, adică o formă trapezoidală în cazul locuinţei 6 (PI. 4/a) ${ }^{35}$. Latura cea mai lungă ce a putut fi măsurată este de 3,62 m., la L. 8 (fiind vorba, de fapt de distanţa între pereţii de SV şi NE vezi Planşa 5). Folosind standardele clasice, putem spune că sunt locuinţe "mici" şi "mijlocii"; şi în acest caz, însă, este discutabil că spaţul locuinţei se reduce la spaţul gropii. Un argument ar fi că se întâlnesc gropi de par de colţ, dar nu la toate locuintele ${ }^{36}$, si nici la taate colţurile ${ }^{37}$. Astfel de situatii se întâlnesc cu claritate tot la locuintele 4 şi 6, unde gropile de par mărginesc fie numai latura de SV (L. 4), fie numai latura de SE (L. 6), aceste laturi fiind singurele la care se poate presupune cu oarecare îndreptătire că marginile gropii locuinţei ar coincide cu laturile locuintei.

Progrese semnificative pentru lămurirea acestui aspect nu se vor putea face, însă, decât prin practicarea unor săpături sistematice în suprafaţă.

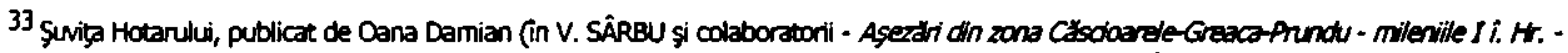
Id. Hr., Brăila 1996) şi Vadu Codrii, cercetat și publicat de Marin Nica (SCMA 45, 1994, 1, p. 61-70); in acest ultim punct autonu acestori rânduri a mai fâcut cercetări în 1997-1998 (nepublicate; vezi toussi rezumatele Sesiunilor Naţionale de Rapoarte), confirmându-se aspectul cultural în discuţe; a apărut insă și un orizont mai timpuriu, databil probabil la jumătatea sec. VI.

34 I. NESTOR, Dacia N.S., II, 1958.

35 Dimensiunea este mică, dar nu neobişnuită (P.I.PANAT, CAB, I, 1963, p. 106, unde B.1 = 2,8/2,6 m.).

36 Similar la Şendreni (D.GH.TEODOR, Danubius, I, 1967, p. 130).

37 Similar P.I.PANAT, CAB, I, 1963, p. 106; M. CONSTANTINIU, P.I.PANAT, CAB, II, 1965, p. 98-140, in special B.6 de la Băneasa-Sat, cu pari de colş pe numai două laturi.
} 
Nu au putur fi surprinse aprazpe nici un fel de amenajări ale pereţilor gropii, nici măcar în cazul celor susceptibili a coincide cu pereţii exteriori ai locuinţei (paramentul propriu-zis). Asemănător, nu s-a putut constata nici cea mai modestă amenajare a podelelor, în afara faptului firesc că erau uşor bătute (tasate). Astfel de amenajări precare sunt însă foarte obişnuite în Câmpia română ${ }^{38}$. Intrări în groapa locuinţelor, amenajate în părnânt, nu au fost surprinse decât în două cazuri: la L. 4 un gârlici (o rampă), lung de 0,8 m., iar la L. 6 o treaptă interioară, alăturată unui par de sprijin (probabil pentru uşă).

Între puţinele amenajări interioare care au putut fi surprinse ar fi de amintit situaţia din Locuinţa 7, unde, de-a lungul peretelui de SV al gropii a fost cruțată o "banchetă" joasă, nu mai înaltă de $0,15 \mathrm{~m}$ (PI. 5). Rostul unei astfel de amenajări ar putea fi însă acela de policioară, pentru ca vesela să nu stea pe nivelul "podelei".

Orientarea locuinţelor este mereu aceeaşi, în sensul că cuptoarele se află întotdeauna pe coltul de N, axul lor longitudinal fiind paralel laturii de NE, Cu gura spre peretele de SE, perete pe care s-a găsit şi intrarea, atunci când s-a găsit; adică un plan şi o organizare a interiorului foarte obişniuite în epocă. Peretele de SE nu a fost cercetat. în cazul locuintelor 7 şi 8 , dar se poate spune cu certitudine că o intrare amenajată în groapa locuinţelor 9 şi 10 lipsea, intrarea fiind probabil de lemn (scară) şi nelăsând urme observabile.

Asemănările cu locuinţele de secol VII se continuă prin faptul că adâncimea gropii locuinţelor faţă de propriul nivel de călcare oscilează nesemnificativ în jurul la $0,7 \mathrm{~m}$. 0 altă asemănare constă în scobirea cuptorului într-un colţ cruțat, care este întotdeauna cel de nord. Nici un cuptor nu s-a conservat suficient del bine pentru a alimina dubiile asupra sistemului constructiv, iar seria comparativă este prea scurtă, dar, aproape sigur, şi aceste cuptoare aveau horn, împins spre spate. Profilul cuptorului din L. 6 se ridică în partea posterioară aproape vertical (PI. 4/b), cєea ce exclude o cupolă, existând chiar indicii ale unui grătar la 20 de cm. înălţime faţă de vatră, peretele "coşului" riđicându-se încă 20 de cm.

Cuptorul din L. 4 ar fi putut fi martorul cel mai complet, însă a fost distrus înainte de a fi desenat în detaliu. Observaţile făcute înainte de eveniment permit însă o descriere destul de amănunţ̧ită: planul este circular, cu un diametru de $60 \mathrm{de} \mathrm{cm}$., peretele cuptoruilui ridicându-se până la 20 de cm. înălţime, hornul ridicându-se încă $30 \mathrm{de} \mathrm{cm}$., plasat asimetric spre stânga, pe un plan circular, cu diametrul de 35 de cm., separat (?) de camera de ardere printr-un "grătar", în care însă nu au putut fi văzute găuri de acces (partea conservată fiind însă mică); surprinde consistenţa şi grosimea scăzute a acestui presupus grătar. Aparent, accesul aerului cald, din camera de ardere în camera de evacuare (hornul), se făcea prin două canale laterale, aproape verticale (PI. 4/a). Partea frontală a cuptorului era distrusă, inclusiv o parte a vetrei. În faţa gurii se afla o alveolă cu diametrul de cca. 30 de cm., plină cu cenuşă şi cărbune de lemn.

Cuptorul din L. 7, cu plan ovoidal, cu diametrul longitudinal de $70 \mathrm{de} \mathrm{cm}$. şi cu diametrul transversal de 51 de $\mathrm{cm}$. a fost distrus aproape complet de o groapă medievală, păstrându-se numai partea frontală; aceasta este însă foarte semnificativă, de o parte şi de alta a gurii peretele ridicânduse aproape vertical 45 de $\mathrm{cm}$. Şi această formă exclude o închidere centrală a cupolei ${ }^{39}$.

\footnotetext{
38 Acest tip de locuinţă este de departe dominantă in Campia română; trimiterile bibliografice fiind în acest caz superflue. Comparaţia cu aşezările dunărene nu-şi are rostul, fiind vorba de altă organizare a spaţului (cvasi-urbană), alt sol (nisipos sau pietros) şi altă conjunctură constructivă (peste rămăşițele locuirii mai vechi).

39 Cuptoare de un tip asemănător la Giuleşt (V. ZRRA, M. TUDOR, Bucureşti I, 1954, p. 40-43), Bucureştii Noi (P. I. PANAT, $C A B$, I, 1963, p. 106 şi următoarele), Şendreni (D. GH. TEODOR, Danubius, I, 1967, p. 130.
} 
Despre astfel de cuptoare cu horn s-a susţinut, probabil cu îndreptăţire, că sunt cuptoare multifuncţionale, putând servi la încălzirea hranei, la uscarea grânelor - în cazul existenţei unei tăvi mari (din care nu s-au găsit însă nici un fel de rămăşiţe), sau chiar la coacerea vaselor ceramice, pentru uz casnic, adică vas de vas ${ }^{40}$. In cuptorul din L. 7 au fost găsite patru pietre mari de calcar (care lipsește din structura geologică a locului), cere ar fi putut servi ca fondant la prelucrarea (secundară) a metalului, ipoteză întărită de prezenţa unor zguri de fier.

Cuptorul din L. 8 a trebuit refăcut (vezi PI. 4/d, secţiunea prin complex, unde, în partea posterioară, o umplutură cu inventar mărunt dar similar celui din restul locuinţei, este acoperită de un strat de lut depus, care intră sub cupola cuptorului) deoarece colţul de nord al locuintei a nimerit peste umplutura unei locuinţe de secol VII (L. 3), construcţia obişnuită prin scobire într-un colţ cruţat, de lut, nemaifiind viabilă (vezi şi PI. 4/c-e). La acest cuptor ar fi de remarcat utilizarea pietrelor mari la baza părţii dorsale a cuptorului, cât şi gura laterală, în afara axului longitudinal. Aceste caracteristici însă nu par nimic altceva decât nişte improvizaţii, datorate stângăciei în construirea din lut a unui cuptor, tipul uzual fiind cel descris anterior, aşa cum rezultă şi din bibliografie.

Din Locuinta 5 a fost surprins numai un colt, pe S.XVI b, la 3 metri est de L. 4, pe o lungime de $1,5 \mathrm{~m}$. de-a lungul profilului de NNV. La o adâncime de numai $0,2 \mathrm{~m}$.(solul suferind acolo decapări recente) s-au descoperit resturile incendiate ale unei amenajări de suprafaţa (numită, destul de ipotetic, "locuinţăa"), respectiv chirpic ars, amestecat cu cioburi Dridu puţine şi destul de fragmentate. Prăbuşitura era perforată de M151 (infans I) din cimitirul de secol XVI. Cercetarea a fost sistată din cauza iernii şi nu a putut fi reluată în acest punct, care face parte din arealul distrus de buldozer la 6 martie 1992. Ceramica, câtă este, are similitudini numai în cea din G. 1, care, după cum vom vedea, poate fi considerată cea mai târzie. Faptul îl discutăm aici, în paragraful destinat locuinţelor, fiindcă complexul - din nefericire cercetat parţial - pare să confirme că, la finele evoluţiei culturii Dridu, locuinţelor semi-îngropate le urmează locuinţele de suprafaţăâ ${ }^{41}$.

Inventarul este aproape exclusiv ceramic, în afara unor fragmente de zgură şi a unor cuie neputând aminti decât un vâf de cuţit (în L. 8) şi un fragment de plăsea de os, decorat prin incizii fine (PI. $9 /$ t); cantitativ, inventarul variază de la mediu (L. 4, L. 8) la foarte slab (L. 6). În legătură cu această ultimă situaţie, ar de menţionat că cele trei fragmente de borcane din L. 6 au fost găsite in cuptor, restul locuinţei fiind perfect lipsită de inventar, ceea ce aduce àminte de locuinţele de secol VII; întâmplător sau nu, aceste fragmente ceramice par să prezinte caracteristicile cele mai timpurii, comparativ cu restul sitului.

\section{CUPTÓARELE ÎN AER LBER}

Primul cuptor de epocă Dridu (notat C. 2) a fost descoperit în caseta XoxII H (sectorul B), fiind, neîndoielnic, un cuptor de pâine ( $\mathrm{Pl} .7 / \mathrm{a}-\mathrm{c}$ ), probabil unul dintre cele mai complete complexe de acest tip descoperite la noi în ţară ${ }^{22}$. Planul este cvasi-circular, diametrul longitudinal (axul gurii) fiind

\footnotetext{
40 D. GH. TEODOR - Teritoriul est-carpatic in veacurile $V-x I$, laşi, 1978, p. 105-106, in special fig. 64/4, cuptorul din 8.9 de la Dodeşti-Vaslui, foarte asemănător cu cel din B.4 de la Vadu Anei.

41 M. COMŞA, Ilfov - file..., 1978, p. 114; GH. MÃNUCU-ADAMEŞTEANU, CAB, IV, 1992, p. 67; nu trebuie să ne aştemptăm insă ca fenomenul să fie sincron şi generalizat.

42 Tipul acesta de complex este apoape nelipsit în aşezările cercetate integral (sau intr-o măsură semnificativă) pentru culturile Ipoteşti-Cándești şi Dridu, deservind întotdeauna un grup de locuinţe (S. DOLINESCU-FERCHE, Dacia N.S., XOOVI, 1992, cáte unul pe fiecare nivel la Dulceanca IV, p. 130 şi fig. 3/2 - exemplar complet - şi p. 153, fig. 2/2; E. ZAHARIA - Sżpäturile de la Dridu, 1967, p. 73, fig. 44; M. COMŞA - Cultura materialä veche románească (Aşezănile din secolele VII-X de la Bucov-P\%oieşti, Bucureşti, 1978 , p. 37-39, fig. 27 - cinci exemplare, din care unul complet.
} 
de 1,43 m., iar diametrul transversal de $1,55 \mathrm{~m}$. Deschiderea gurii se realizează spre SV. Înălţimea interioară este de $0,43 \mathrm{~m}$. Cuptorul a fost realizat prin scobire în lut, fiind complet îngropat faţă de nivelul de călcare al contemporanilor. Accesul se făcea printr-o groapă largă de 1,65 m. de la nivelul de săpare şi numai $0,95 \mathrm{~m}$. la nivelul de jos (al vetrei), lungimea fiind mai mare de 1 metru (cât a fost cercetată), axıll longitudinal al gropii fiind deplasat cam cu $10^{\circ}$ faţă de axul cuptorului. Starea de conservare surprinzător de bună nu se poate explica decât prin ipoteza că agregatul ar fi fost părăsit în stare de funcţionare, dar cu intenţia de reutilizare, situaţie în care, foarte probabil, a fost umplut cu pământ, tocmai pentru a împiedeca surparea. Reutilizarea, însă, nu s-a mai produs. Rezultatul açastor precauţii este că s-a surpat doar o mică parte din zona frontală, însă numai câţiva centimetri, după cum se poate observa pe desenul de profil în secțiunea $A B(P I .7 / b)$. Nu se poate concluziona decât că cuptorul era plin cu pământ în momentul surpării; despre o umplere naturală eu pământ atâta vrefne cât complexul era întreg - nu poate fi vorba. Surpătura este deci rezultatul unei tasări a pământului.

Complexul confirmă teoriile despre părăsirile temporare ale aşezărilor de tip pendul ${ }^{43}$. Ar mai fí de adăugat că deasupıa cupolei era prăbusitită o bâmă complet arsă, lungă de 65 şi groasă de 8-9 cm, ceea ce ar sugera existenţa unui acoperiş împotriva ploii, cât şi incendierea amenajării după părăsire.

Complexul este foarte slab dotat cu inventar - ceea ce nu ar trebui să mire la un cuptor de pâine - putinele cioburi Dridu fiind amestecate cu cioburi dacice, acestea mai ales în cuptor (prezenţa acestora în cuptor credem că este deja explicată), dar şi în nivelurile de umplere ale gropii de acces, rezultat al prăbuşirii pereţilor laterali, doar "pođeaua" gropii furnizând informaţii clare despre utilizatorii agregatului. De asemeni, stratigrafia gropii de acces, pe profilul de vest al casetei, nu a lăsat nici un dubiu asupra apartenenţei complexului la nivelul Dridu.

Al doilea cuptor de epocă Dridu ( $C .3)$ pare să fi fost unul foarte asemănător cu cel mai sus descris, însă a avut cu totul altă istorie. Iniţial a fost degajată, pe mijlocul secţiunii S. XXXIV (sector B), la 0,4-0,7 m de solul actual, un calup considerabil, constituit din cca. $10 \mathrm{kG}$. de zgură de fier şi mai multe zeci de kG. de pământ puternic ars, calup compact, foarte greo de gpart, rezultat din aruncarea, la cald, a resturilor unui cuptor de redus minereu، După ridicarea acestor deseuri a fost precizat,la $-0,9 \mathrm{~m}$., conturul unui cuptor cvasi-circular, cu diametrul longitudinal de $1,65 \mathrm{~m}$. şi cu diametrul transversal săpat pe 1,26 m.(estimat 1,7 m.), orientat cu gura spre SSE (PI. 6/a). Pereţii cupolei s-au păstrat pe maxim $10 \mathrm{~cm}$., mai ales spre zona posterioară, fiind distruşi şi evacuaţi încă din vechime, fiindcă nu s-au găsit nici un fel de resturi (pereţii cuptorului de redus minereu erau mult deasupra, având altă consistenţă, culoare şi grosime). Spre SE a fost surprinsă groapa de acces a cuptọrului, care continua în caseta XXIV A, cu formă elipsoidală, având pe axul NV-SE 1,85 m., iar pe axul SV-NE 2,04 m. Fundul gropii era uşor albiat, coborând de la $0,9 \mathrm{~m}$. la $1 \mathrm{~m}$. la centru, alveola fiind umplută cu cenuşă, cărbune,zgură metalică măruntă, cioburi mărunte arse secundar, umplutură net distinctă de aceea compactă şi masivă întâlnită între 0,4 şi $0,7 \mathrm{~m}$. adâncime.

Similitudinea celor două complexe - C. 2 şi C. 3 - este evidentă, în dimensiuni, plan, chiar şji în uşoara dezaxare a gropii de acces, doar orientarea fiind diferită (cu $70^{\circ}$ ). Particularităţile C. 3 ne întemeiază convingerea că complexul a avut patru faze de ưtilizare, după cum urmează: a) cuptor de pâine, care s-a prăbuşit şi a fost dezafectat, resturile cupolei fiind aruncate; b) utilizarea vetrei în prelucrarea secundară a metalului (fierărie), după cum atestă zgura năruntă, dar numeroasă din cenuşar; c) groapă menajeră (umplutura de la $-0,9 \mathrm{~m}$. la $-0,7 \mathrm{~m}$.); d) utilizarea întregului complex ca groapă de deşeuri pentru activitatea

43 de ex. GH. MÃNUCU-ADAMEŞTEANU, CAB, IV, 1992, p. 57. 
de reducere a fienului, după cum atestă bucăţile masive de cuptor şi zgură (similare celor găsite la C. 4, vezi infra), cât și un fragment de tub suflant ceramic, al cărui capăt îngustat era astupat de metal.

Atribuirea culturală a complexului C. 3 este deosebit de clară, cioburi Dridu fiind găsite la toate nivelurile gropii, inclusiv panouri mai mari, puternic arse secundar, folosite în procesul de reducere ca factor refractar, aşa cum atestă foarte clar C. 4.

În caseta XOXIII $C$, în carourile 16-17 (corespondente secţiunii XXXIII), au aparut, încă din stratul arat, bucăţi mari de zgură, "lupă" de fier, chirpic masiv, puternic ars, de culoare vineţie, amestecate cu cioburi Dridu arse secundar. După îndepărterea acestui strat au apărut fragmente de perete de cuptor - din care însă numai unul mai stătea în poziţia funcţională - a căror grosime mergea până la 0,4 m., de culoare albastru-vineţie spre interior, care era vitrificat şi cu urme metalice pe suprafaţă, şi roşu intens pe exterior. Planul complexului nu a putut fi precizat însă decât la -0,50-0,55 m., unde s-a desenat conturul negativului agregatului, de formă dreptunghiulară, cu lungimea de 1,85 şi lăţimea de 0,82 m., acestea raṇrezentând dimensiunile interioare ale unui cuptor de redus minerers de fier, cu orientarea laturii lungi VSV-ENE (PI. 6/b-c). Profilul arsurii negativului cobora oblic până la $0,7 \mathrm{~m}$. sub solul actual, cu fund plat,orizontal, perforat în câteva locuri chiar de către utilizatorii cuptorului, atunci când au spart cuptorul petitru recuperarea cât mai completă a metalului obţinut. În umplutura negativului s-au găsit fragmente de perete, bucăți de zgură şi de "lupă" metalică, ceramică nisipoasă puternic arsă secundar, lemn ars mărunt şi nisip de culoare albăstrie.

Starea de conservare precară a complexului se datorează chiar tehnologiei de producere a fierului în epocă, cât şi tipului de cuptor folosit, ce nu permitea strângerea metalului rezultat decât prin distrugerea pereţilor cuptorului, care era de unică utilizare ${ }^{44}$. Ar putea pare surprinzător fundul plat şi orizontal, cât şi grosimea redusă a arsurii a ceea ce am numit mai devreme "negativ", notat pe desenul de la PI. 6/b "pseudo-vatră". Am optat pentru acest termen, pentru că, în cazul constructiv şi funcţional în discuţie, pe "vatră" nu s-a produs o combustie directă.

Pentru a înţelege rămăşițele unui astfel de complex este necesar să descriem construcţia şi funcţionalitatea unui cupter metalurgic de uniç întrebuinţare ${ }^{45}$. Indiferent ç planul este rotund (situaţia obişnuită) sau rectangular, se sapă o groapă adâncă de 0,3-0,4 m., care se umple cu nisip, cioburi sau alte materiale care au proprietatea de a acumula şi reda căldura, ceea ce favorizează păstrarea unei temperaturi constante şi prelungirea efectelor combustiei. În plus, nisipul are funcţie de fondant. La marginile gropii începe ridicarea pereților cuptorului (din lut, dar putând conţine orice material refractar), care sunt groşi (în principiu cel puţin $0,5 \mathrm{~m}$.) şi uşor înclinaţi spre înăunmu, amândouă caracteristici destinate să prevină deteriorarea cuptorului în tiropul procesului, având în vedere presiunea considerabilă care se formează în interior; în paralel se încarcă şarja, aşezându-se alternativ, peste tăciuni, câte un rând de minereu şi câte un rând de cărbuni (mangal sau alt combustibil). Având în vedere mărimea planului la baza .cuptorului, înălţimea lui ar fi putut fi între 1,5 şi 2,5 metri, partea superioară fiind mult îngustrită dar deschisă (ca un coş). La nivelul solului, cuptorul era prevăzut cu cel puţin un tub suflant, din ceramică - a şi

\footnotetext{
44 Cuptoarele reutilizabile se cunosc din epoç dacic (Z. SZÉKEY, MCA, V, 1959, p. 231-246; E. BUOR, L. ROȘU, ReVMU, V, 1968), romană (V. H. BAUMAN, Peuce, DX, 1984), post-romană (E. LAROSLAVSOHI, R. PEIROVSZKY, Tibiscus, III, 1974, cu datare mai probabilă în sec. VI-VII), sau chiar in secolele IX-X, dar într-o zonă cu traditje metalurgič (Ghelar, Muntji Poiana Ruscăi - N. MAGHAR, ST. OLTEANU - Din istoria mineritului, 1970, p. 102). Regula in epocă pare a fi însă cuptorul de uniç̆ intrebuintare, mai puţin pretențios (J. MARÉCHAL Dictionaire archélogique des tectniques, Paris, 1964, bitul Métallugie, 0. 622-675; E. IAROSLAVSOHI, AMN, XIII, 1976)

45 Înţelegerea tipului constructiv-funcțional mi-a fost uşurată de rezultatele experimentului etno-arheologic Schmidt-Avery (tribul Haya, NV Tanzaniei - in C. RENFREW, P. BAHN - Archaeological Theories, Methods and Practice, London, 1991, cap. Archaeometa/lurgy, p. 296. şi urmatoarele, fig. de la p. 305), unde este vorba despre un cuptor de plan circular, dar cu funcţionalitate similară celui pe care il prezentăm.
} 
fost găsit un fragment dintr-un astfel de tub, cu diametrul interior de $2,5 \mathrm{~cm}$. (Pl. 11/e) -, tub care traversa peretele de lut, şi prin care se introducea aer, pentru îotreţinerea şi reglarea combustiei, cu ajutorul unor foale. În principiu, aerul ar trebui să fie preîncâlzit ${ }^{46}$, de la un foc deschis, însă, în cazul dat, nu există nici o evidenţă de acest fel.

Faţă de modelul teoretic prezentat, C. 4 avea, aşa cum arată fragmentul de perete inferior care s-a conservat în poziţie funcţională, groapa cu nisip suprapusă, cel puţin pe margini, cu un capac de lut gros de 0,1 m., de formă alveolată, ceea ce ar însemna că metalul topit se strângea la centru, pe nisip ${ }^{47}$; dupa cum arată perforaţiile din fundul gropii de nisip, metalul s-a scurs şi spre latura de est a cuptorului.

Cuptoarele de redus minereu sunt destul de rare pentru această perioadă istorică, dar cele de formă rectangulară sunt rarisime, cunoscându-se numai încă un exemplar, la Epureni (jud. Vaslui), asemănător ca formă şi dimensiuni, despre care însă este descris ca având o vatră foarte groasă, ceea ce presupune un alt tip funcţional, în care s-a renunţat la groapa cu nisip ${ }^{48}$.

\section{GROPI}

Groapa 1 (G. 1) a apărut în caseta V B, având o formă dreptunghiulară alungită, cu colţuri rotunjite, cu dimensiunile de 2,5/1,36 m., orientată $\mathrm{N}-\mathrm{S}$, cu ñund uşor alveolat, la adâncimea de 0,8 m. faţă de solul actual. În partea nordică a gropii au fost găsite urme de arsură care ar putea fi de la un cuptor distrus, caz în care ar fi vorba de o groapă de acces. Cert este că groapa a fost folosită, cel puţin într-o a doua fază, ca groapă menajeră (?), fiind recuperate destul de multe fragmente ceramice, inclusiv două borcane întregibile de dimensiuni relativ mari. 0 particularitate a acestei gropi o constituie dispoziţia specială a cioburilor la nivelul superior $(-0,25-0,40 \mathrm{~m}$.); la acest nivel cioburile au fost aşezate pe cant ("în picioare"), configurând un cerc destul de imperfect (sau un patrulater cu laturile mult rotunjite) cu raza de circa un metru. O astfel de dispoziţie nu poate fi întâmplătoare, ci în legătură cu o practică rituală pe care nu o cunoaștem. Cu titlu de curiozitate, semnalăm că în S. XVI s-a descoperit o groapă (G. 14) în care, asemănător, cioburile erau aşezate pe cant, configurând un cerc, la partea superioară a umpluturii, complex care însă aparţine evului mediu dezvoltat, respectiv sfârşitului de secol XV sau secolului al XVI-lea.

Groapa 2(G. 2) a apărut la capătul inferior al secţiunilor XV şi XVI b, în carourile 1-2, la numai câțiva metri mai jos (spre sud-vest) de L. 4; puţinul material ceramic recuperat pare să indice însă

\footnotetext{
46 Aerul preincălzit ia $600^{\circ} \mathrm{C}$, tirajul foarte bun (pe 8 guri de suflare), proprietăğle termice ale materialului de construcţie (pământ de muşuroi armat cu zgură) şi proprietăţile de fondant ale carburantului (mangal de trestie) au permis metalurgiştilor Haya să obţină oţel carbon mediu cu aproape două milenii înaintea europenilor, folosind un fumal asemănător celui descris aici (RENFREW - BAHN, Archaeological. .., p. 305).

47 În majoritatea cazurilor, cuptoarele de redus minereu sunt adâncite la mijloc, pentruı a strânge tot metalul topit. La construcţiile mai sofisticate există o cameră (groapă) inferioară, în acelaşi scop, sau canale de scurgere spre exterior (la furnalele făcute in pantă). Constructorul de la vadu Anei a folosit o altă soluţe, cu o cuvă alveolată, deschisă la mijloc, deasupra gropii de nisip. Nisipul ca factor refractar şi fondant este atestat şi la Hlincea (sec. XIII-XIV, N. MAGHIAR, ŞT. OLTEANU, Istoria..., 1970, p. 106) şi Federesti (G. COMAN, in Danubius 4, 1980, 161-184).

48 În ciuda similitudinii de plan (1,35 / 0,6 m), functionalitatea și sistemul constuctiv par a fi diferite (D. Gh. TEODOR - AthMold, XI, 1979, p. 148). Fumalele dreptunghiulare sunt cunoscute in Basarabia, insă pentus cultura Cemeahov (informatje I. TEUNOV, Institutul de Artheologie Chişinău - căruia î multumesc pentru amabilitate), sunt insă foarte numeroase în Polonia de sud (K. BIELENIN, ArchiPolona, $X$, 1968), pentu chiar perioada în disaujie. Nu evistă însă nici cel mai mic indiciu al prezentei unei populaţi nordice la Vadu Anei, între mijloacele de expresse decorativă ale celor două zone existând diferențe mari (decor ştenţat, realizat cu rotite ş. a., A. BUKO - Ceramika Woesnopolska, Wrodaw, 1990, fig. 55). În Danemarca, tipul de cuptor metalurgic cu groapă este foarte bine cunoscut, fiind descoperite 5000 (!) de piese, datate între secolele I şi VII; nu există descoperiri, insă, pentru secolele VII-X, deci tipul functional utilizat nu este cunoscut (Olfert VOSS, Iron Smeting, in Digging into the past, ed. S. HVASS şi B. STORGAARD, Aartus, 1993, p. 206-209).
} 
contemporaneitatea cu locuinta de suprafaţa (L. 5), aflându-se deci la circa 10 metri VSV de aceasta. Numele de "groapă" este întrucâtva impropriu, neexistând semne clare că ar s-ar fi fácut o amenajare în acest sens, deci că purtătorii culturii Dridu ar fi săpat groapa (PI. 7/e). Complexul stă deasupra şi pe centrul unui complex dacic, o groapă rotundă, cu diarnetul de 3,5 metri, cu un profil asemănător unei farfurti, cu adânciturĕ la centru. Stratul de cultură Dridu, care coboară de la cele două locuinte spre apă, pe o grosime de 0,1-0,15 m., se alveolează în dreptul complexului dacic, coborând la mijloc până la $-0,45 \mathrm{~m}$. Doar spre ENE - adică în partea mai înaltă a reliefului pe care se așează complexul - profilul coboară 0,25 m., amintind de profilul unei gropi sau chiar al unei locuinţe puţin adâncite. Complexul este dificil de interpretat. Nu este o groapă, în accepţiunea obişnuită, iar planul rotund şi profilul fac aproape imposibilă interpretarea ca locuinţă; la limită, ar putea fi planul unei iurte, dar invebtarul sărac nu oferă indicii suplimentare, lipsind obiectele tipice pentru populaţile semi-nomade, cum ar fi găleţile (cazanele) de lut. În lipsa unei evidenţe, am inclus complexul categoriei gropilor, în primul rând datorită unui complex similar (G. 3), care oferă mai multă certitudine asupra funcţionalităţii. Mai rămâne de observat că suprapunerea de plan, peste un complex la Téne, nu este un lucru foarte rar la Vadu Anei, inclusiv pentru complexe ale evului mediu târziu (de pildă pe S. VII a, pe S. VII b şi pe S.XVIII a).

Groapa 3 a apărut în secţiunea X0XIII, în carourile 10-12, şi în caseta XXXIII A. Asemănător, complexul suprapune aproape perfect un complex dacic mare, de această dată o locuinţă semi-îngropată, perforată parţial şi de două mici gropi, coborâte din acelaşi strat antic. Complexul Dridu depăşește puţin latura de SV a locuinţei dacice, având o formă aproximativ rotundă, cu diametrul de 4 metri. Profilul gropii Dridu coboară din stratul arat, are un profil conic obtuz, mai accentuat la mijloc (profil în acoladă pe care l-am mai observat, de pildă, la umplutura superioară a $L$. 4), adâncimea maximă fiind de 0,75 m. - sub stratul arat - aşa cum se vede în Planşa $7 / d$. În special fundul gropii era plin de chirpic şi lemn ars, complexul având funcţie menajeră, din umplutură recoltându-se materialul ceramic cel mai bogat. Din partea inferioară a umpluturii a fost recuperat şi un vârf de săgeată triunghiular, care se poate data în secolele IX-X. O posibilă interpretare este că locuitorii evului mediu timpuriu nu au făcut o groapă, ci au folosit o alveolă existentă în teren, pe care eventual au adâncit-o, pentru a-şi arunca deşeurile menajere. Concluzia este valabilă şi pentru G. 2.

O consecinţă a unei asemenea ipoteze este concluzia că între secolul I și şârişitul secolului al Xlea locuirea în zonă a fost sporadică, iar terenul mu a avut funcție agricolă (lucrările agricole ar fi produs, destul de repede, nivelarea). O asemenea explicaţie nu mai rezistă observaţei că şi unele gropi medievale târzii suprapun central (centrat) gropi dacice. Alte explicaţi sunt însă mai mult de domeniul fanteziei; chiar şi aşa, ele trebuie luate în seamă, în absenţa unor explicaţii controlabile. Desigur, e mai uşor de săpat, întro umplutură menajeră, decât în pământ compact. Scopurile pentru care se faceau astfel de gropi putea fi diverse, inclusiv magice, dar mijlocul de a repera poziţia exactă a unei gropi antice era unul singur, radiestezia, pe modelul bine-cunoscut al căutătorilor de apă (fântânarii).

\section{CERAMICA}

Ceramica reprezintă cvasi-totalitatea inventarului recuperat din complexele "Dridu". Ea este singura în măsură să ofere o idee, fie şi imperfectă, despre cronologia aşezării.

Din dorinţa de a descrie cât mai obiectiv ceramica de la Vadu Anei, am alcătuit o bază de date care cuprinde informaţii despre fiecare fragment ceramic, din fiecare complex. Nu este necesar şi nici posibil să public această bază în integtalitatea ei, cu toate variantele de studiu combinatoriu, în 
primul rând datorită volumului mare. Am alcătuit, în schimb, patru tabele concluzive, referitoare la decor (Tabelul 1, vezi infra), profilul buzei (Tabelele 2 şi 3), informaţil morfologice minime (diametral la buză şi la bază) cât şi informaţii despre calitatea pastei, a arderii şi grosimea relativă a fragmentelor (Tabelul 4). Nu am aplicat sistemul Compas, ca pentru lotul ceramic din secolul al VIIlea, în primul rând fiindcă proporţia de fragmente desenate este prea mică în massa totală pentru a fi reprezentativă (ilustraţia încearcă de fapt să ilustreze diversitatea, nu aspectele cele mai tipice ale complexelor), iar în al doilea rând fiindcă, deocamdată, nu am o bază de date comparativă pentru alte situri ale culturii Dridu, cifrele fiind în acest caz nerelevante.

Deşi soluţia aleasă stă mai mult sub semnul improvizaţiei - nu există o sistema, sau cod, al ceramicii de factură Dridu (forme, decor, pastă, ardere, s.a.) - am încercat să sistematizez materialul de aşa manieră încât, în condiţia existenţei unor rapoarte similare şi cât de cât compatibile, comparaţia să fie posibilă, în speranţa că va fi şi benefică.

Au fost alese cinci "complexe-martor" (G. 3, L. 8, C. 3, L. 4, G. 1), selecţionate atât pentru că posedă un inventar ceramic suficient de mare pentru a răspunde unor criterii minime de comparaţie statistică, cât şi pentru că sunt cercetate integral (G. 1, G. 3, C. 3) sau în proporţie de peste $90 \%$ (L. 4, L. 8). Complexele au fost aşezate într-o presupusă ordine cronologică, pentru a obţine o idee, fie şi relativă, asupra evoluţiei unor caracteristici. Ordinea aleasă este rezultatul principiului minimei contradicţii (pe reprezentarea grafič̆). Desigur, este probabil ca unele complexe să fie strict contemporane, ceea ce nu este exclus în cazul G .3, L. 8 şi C. 3, în ciuda unor diferenţe, care pot fi produsul unei variabilităţi individuale fireşti.

Tabelul 1 prezintă, schematic, speciile de decor întâlnite pe fragmente din grupa ceramică A (ceramică nisipoasă, striată) şi grupa ceramică B (ceramică fină, decorată cu linii lustruite) ${ }^{49}$. La grụpa A decorul cu benzi continue orizontale nu lipseşte de pe nici un exemplar de panau inferior, fiind trasat până la 4-6 cm. de bază. Uneori, acest decor se descompune în "portative", în special pe panouri inferioare şi în complexul mai târziu (G. 1); execuţia în general neglijentă a decorului în această fază nu permite o apreciere obiectivă dacă "portativele" sunt rezultatul unei intenţi (optjuni estetice).

Vasele din grupa A decorate exclusiv cu linii orizontale nu reprezintă, în ansamblul sitului, nici o cincime. Celelalte vase au o a doua temă decorativă, tot incizată, aşezată în general pe umăr. Excepţa o reprezintă decorul în "ochi" (specia $k b$ ), care coboară şi pe jumătatea inferioară a corpului; în două cazuri acest lucru se întâmplă şi cu o specie înrudită, cu mai multe benzi în val care nu se suprapun ( $f$ ). De aceea, schema decorativă din tabel ilustează jumătatea superioară a corpului. Schennele, prin natura lor, nu pot surprinde calitatea execuţiei; aceasta este dependentă, fireste, de calitatez pastei, findcă o incizie adâncă şi egală nu este posibilă într-o pastă care cuprinde pietricele (v. Tabelul 4). Pentru a avea totuşi un termen de referinţă, menţionez că ceramica de la Vadu Anei este relativ inferioară calitativ (pastă, decor) celei de la Dridu, pe care am văzut-o în depozitele Muzeului Naţonal de Istorie României.

Graficele sunt menite să pună în evidenţă un eventual vector cronologic şi cultural. Sigur, atunci când o anumită specie decorativă este reprezentată numai de câteva exemplare, risipite în câteva complexe, graficul este îin sine irelevant pentru evoluţia complexelor de la Vadu Anei, dar ar putea fi relevant prin comparaţie cu alte situri. Există însă specii decorative cu o prezenţă suficient de mare pentru a permite observaţii interesante. Un caz este striul pe tot corpul (b), fiind evidenţiabilă absenţa din complexul cel mai târziu (G. 1).

49 Clasificarea este folosită de lucrări de referinţă (R. FlORESCU, în Capidava, 1978, p. 162; E. ZAHARIA, ...Dridu, 1967; P. DIACONU, D. VRÂNCEANU, PaCuiul lui SOare, I, 1972, p. 71-89. 
Cea mal bine reprezentată specie decorativă este cea cu bandă în val pe umăr, suprapusă parţial sau complet striurilor orizontale ( $d b-37,3 \%$ ). Surprinde, aici, procentul foarte scăzut din L. 8. Dacă însă luăm în calcul și specille decorative înrudite șl derivate (eb, efo, $f b)$, vom obșine un grafic relativ echilibrat, care arată că valul pe umăr este caracteristic pentru tot situl, inclusiv pentru L. 8. Pe de alta parte, absenţa derivatelor $(e b$, efb, fb) în $G$. 1 ar putea fi un semnal cronologic de reţinut.

Cel mai interesant grafic este insă $k b$, care indica o propensiune deosebita a decorului in "ochi", pentru perioada finalüa a evoluțiel sitului. Banda în val cu "creastă", cu vâtf frânt (dib, $/ K b$, mb), denumită uneori ş "ghirlandă", pare o rezultantă a execuţiei tot mai neglijente, ceea ce face ca, pe exemplare concrete, valul să aibă înălţime diferită şi pas diferit, fie în aceeaşi trăsătură, fie pe valuri succesive cu aspect diferit. Specia nb s-a întînit numai pe două fragmente ceramice, find greu de spus daco reprezintu degenerarea benzil orizontale sau a banzil oblice scurte $(q)$.

Serile oblice de impunsături cu pieptenele $(p)$, rar intâlnite, dar prezente în toate complexele-martor, formează într-un caz "căpriori", numite uneori sil "paranteze unghiulare". Şirul de alveole pe umắr (o) se întâlneşte, sporadic, în complexele mai timpuril (L. 8) sau mai tâtzli (L. 4, G. 1). În schimb, benzile oblice scurte ("fascil" - q) par să caracterizeze numai complexele mai timpurii (L. 8, G. 3); într-un caz, acestea se asociază cu şirul de alveole pe umăr. Menţionez că fascille lungi, desfăsurate pe toată jumătatea superioară a corpului sau mai mult, lipsesc, ca şi variantele în friză continuă, în jurul corpuluil, sau cele întretăiate rombic, sau organizate pe mai multe registre, aşa cum se intânesc la Capidava sau la Dridu, în complexe de secol X.

TABELUL 1. Clasificarea decorului in cele cinci complexe-martor (orizontul cultural Dridu)

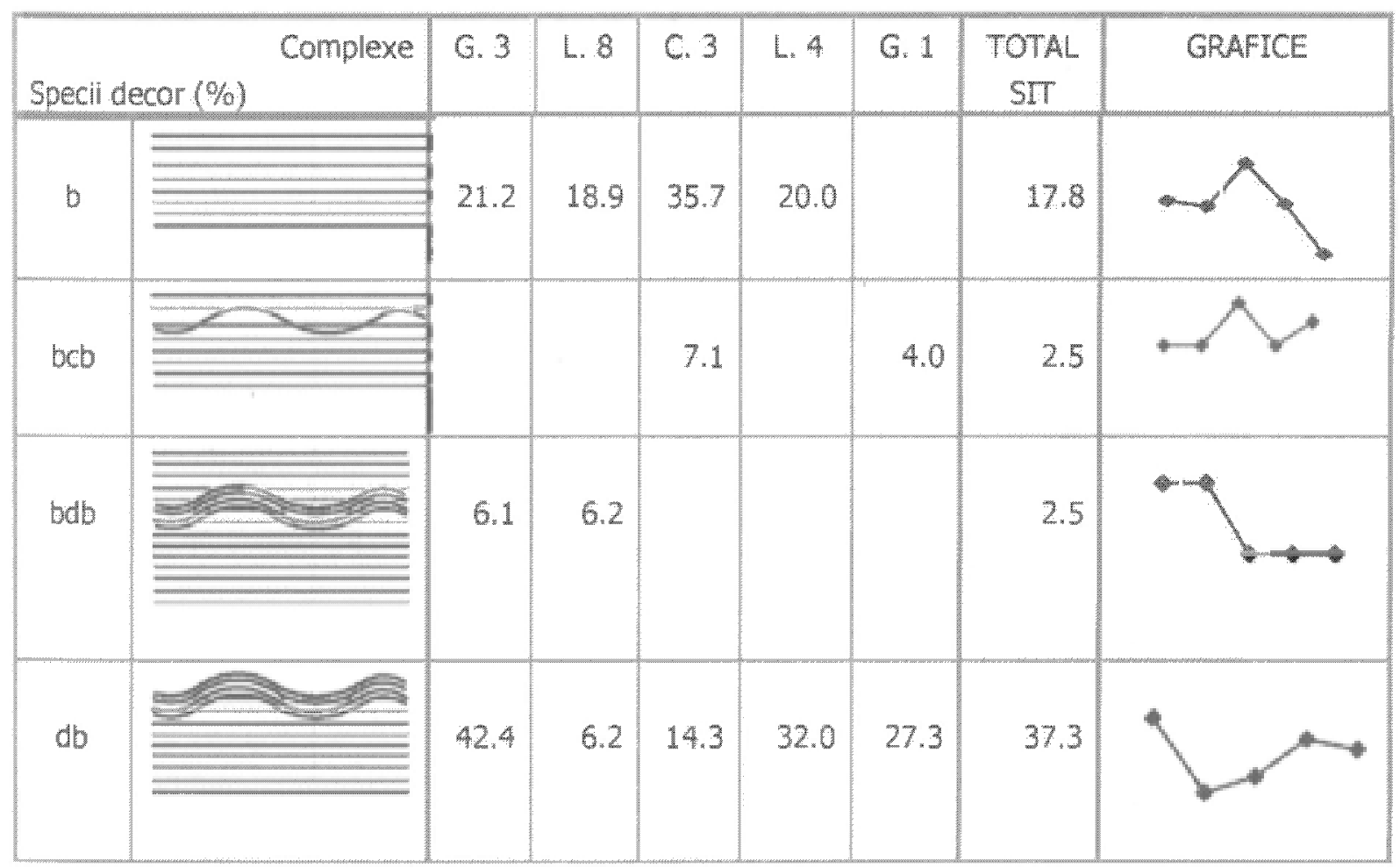


Eugen S. TEODOR

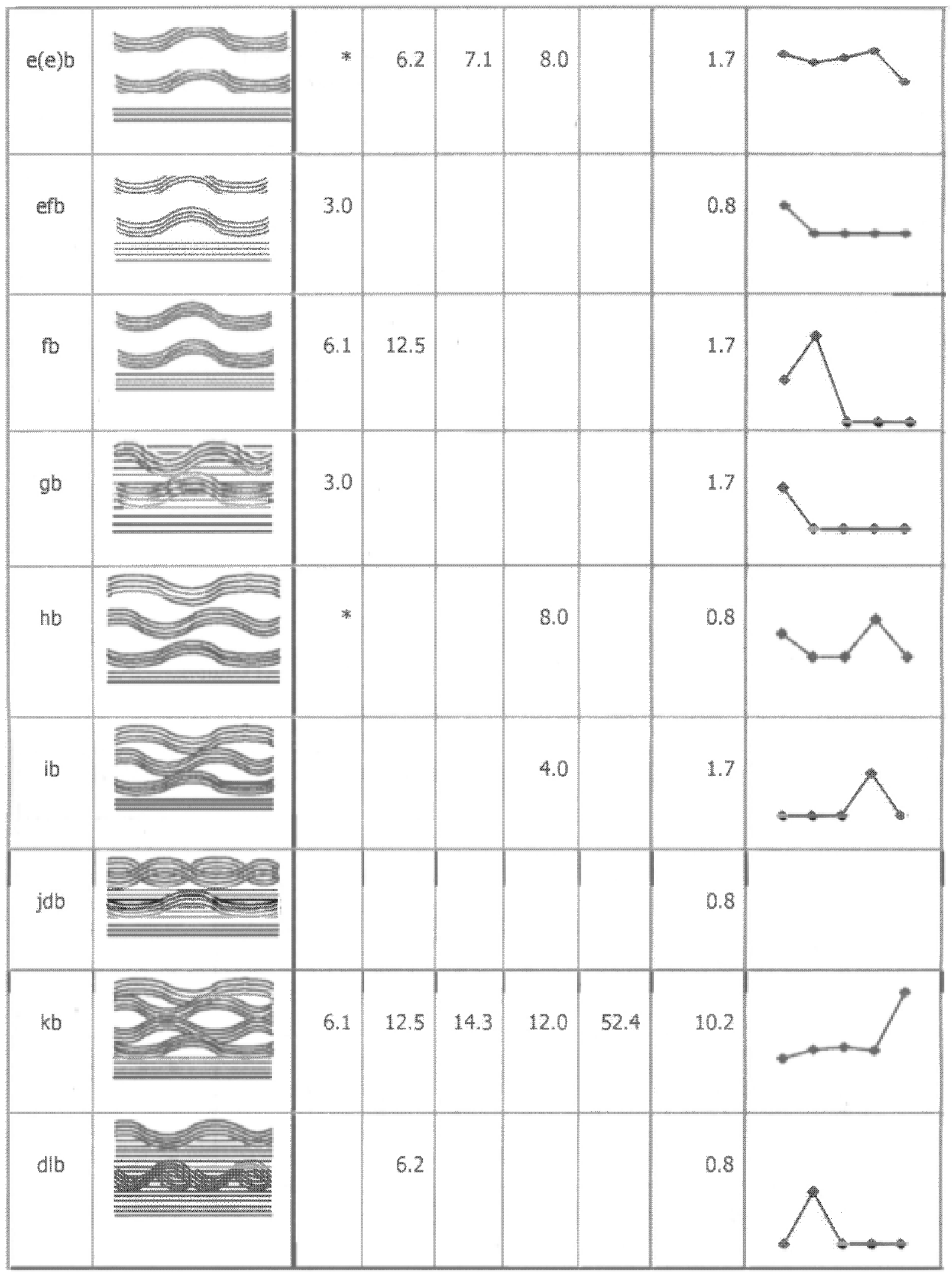


Aşezări de la Vadu Anei

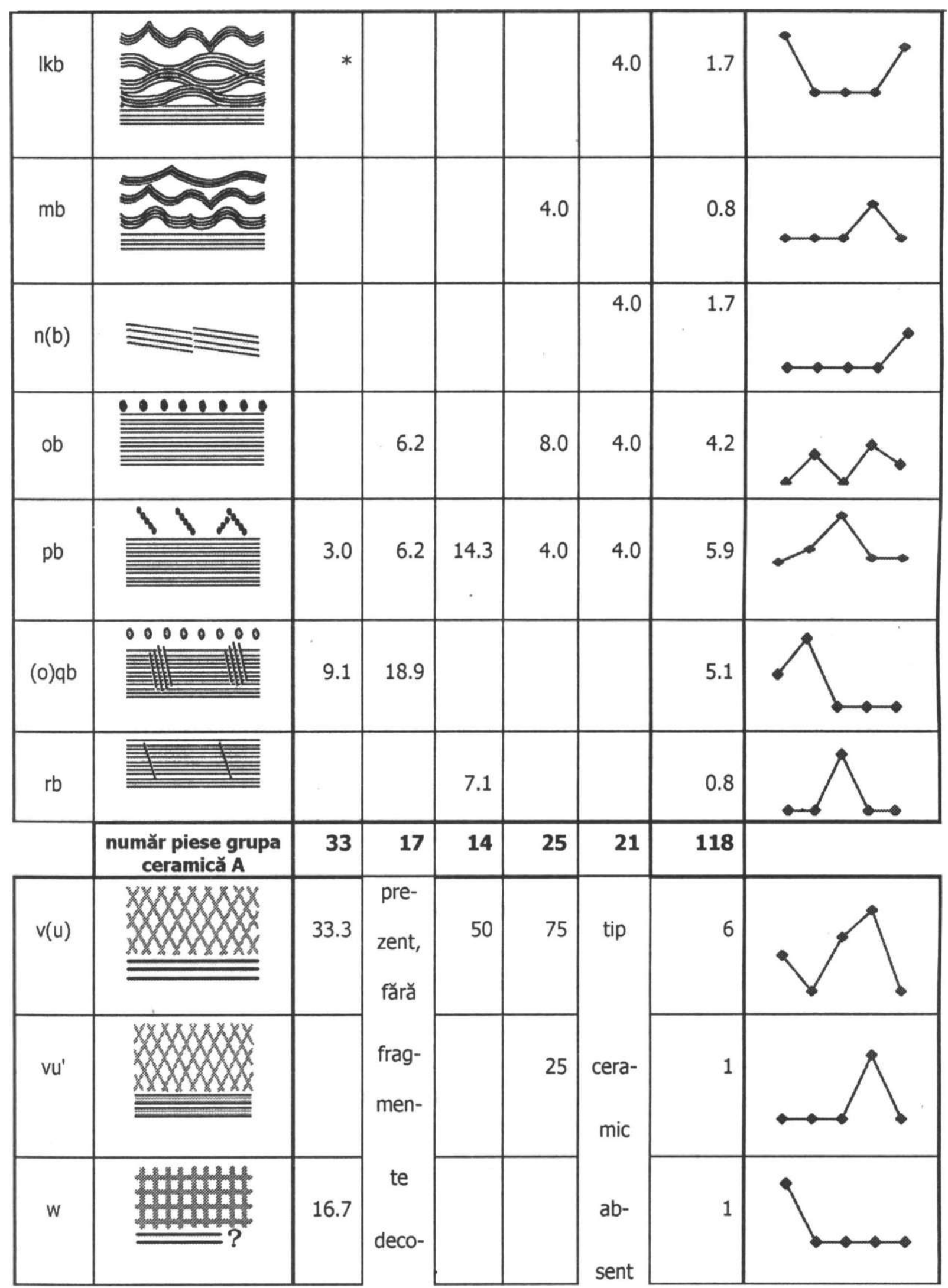




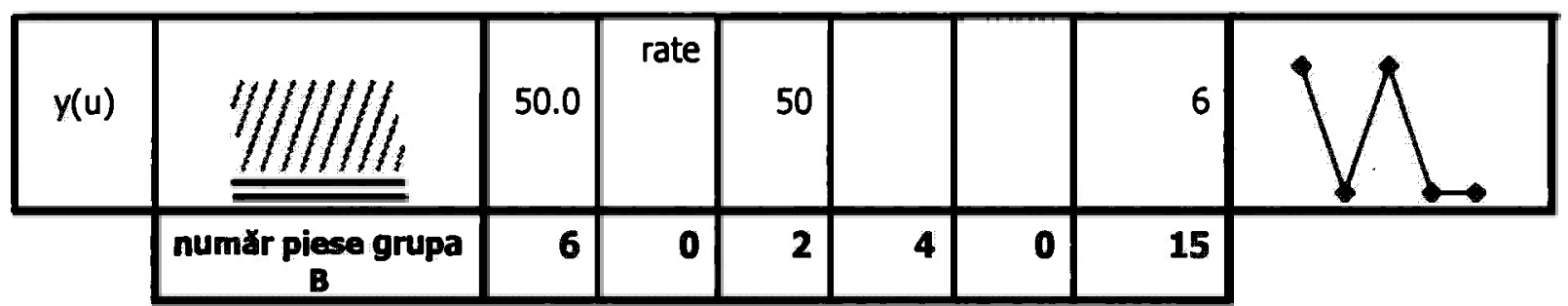

Notă: au fost luate in calculul statistic numai fragmentele de buză-umăr; * arată că respectivul decor există pe cel putin un panou de vas (färă buză).

În ce priveste grupa ceramică $B$ (fină) este de remarcat, în primul rând, absenţa totală a ei din G. 1. În L. 8 au fost găsite câteva fragmente, dar nici unul nu provenea din zona unde se aplică decorul: lustrul - de pe umăr până pe diametrul maxim, încheiat cu două la cinci caneluri superficiale sau striuri adânci. Deşi numărul pieselor decorate este prea mic pentru a specula, putem totuşi observa că reţeaua vertical-orizontală ("tabla de şah" - w) şi liniile oblice ( $y$ ) se întâlnesc numai în complexe mai timpurii (C. 3, G. 3).

Tabe/ul 2 prezintă analitic repartiţia diverselor tipuri de buze funcţie de trei caracteristici: grosime (îngroşată, neîngroşată, subţiată, întoarsă colac), modelare (rotunjită, teșită, şănţuită, cu "cioc") şi răsfrângere (deloc, puţin, mult, foarte mult). S-a fácut distincţie între o buză foarte mult răsfrântă (XXD) şi modelarea cu "cioc" (XFX), situație în care nu toată buza este arcuită, acea excrescenţă răsfrântă putându-se aplica şi la o buză puţin răsfrântă (de ex. AFB, în tabelul 3).

În privinţa grosimii (OXX), remarcăm o creștere a buzelor îngroşate (AXX) și o descrestere a celor subţiate (CXX) şi a celor "colac" (DXX).

În privinţa modelării (XOX), dacă buzele mai mult rotunjite (XAX, XBX) caracterizează - dar în proporţi diferite - toate complexele, buza mai mult sau mai puţin şănţuită (XEX, XDX) se întâlneste numai în G. 1, și încă în proporţii semnificative.

TABELUL 2. Clasificarea buzelor dupâ grosime (OXX), modelare (XOX) şi răsfrângere (XXO)

- lotul cultural Dridu -

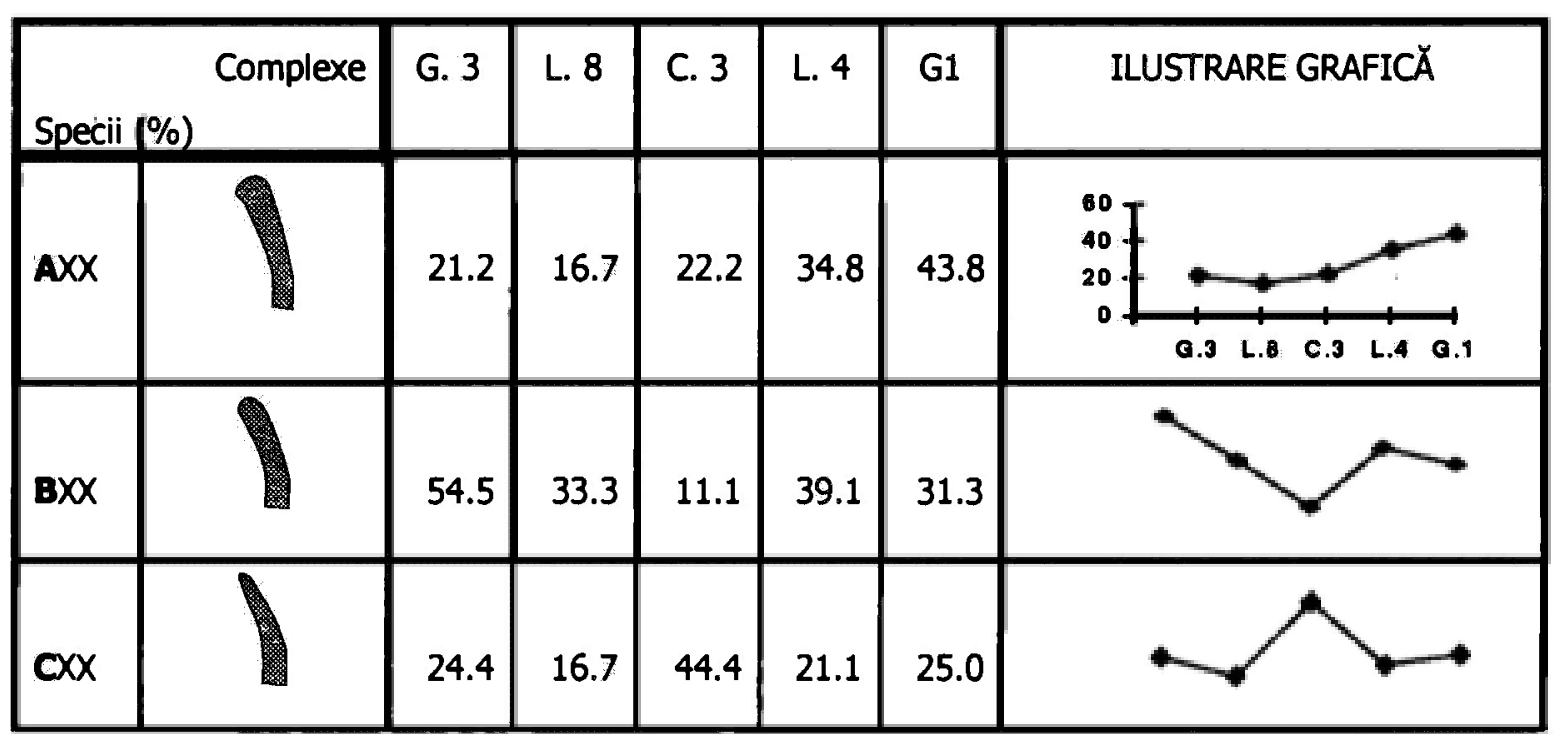


Aşezäri de la Vadu Anei

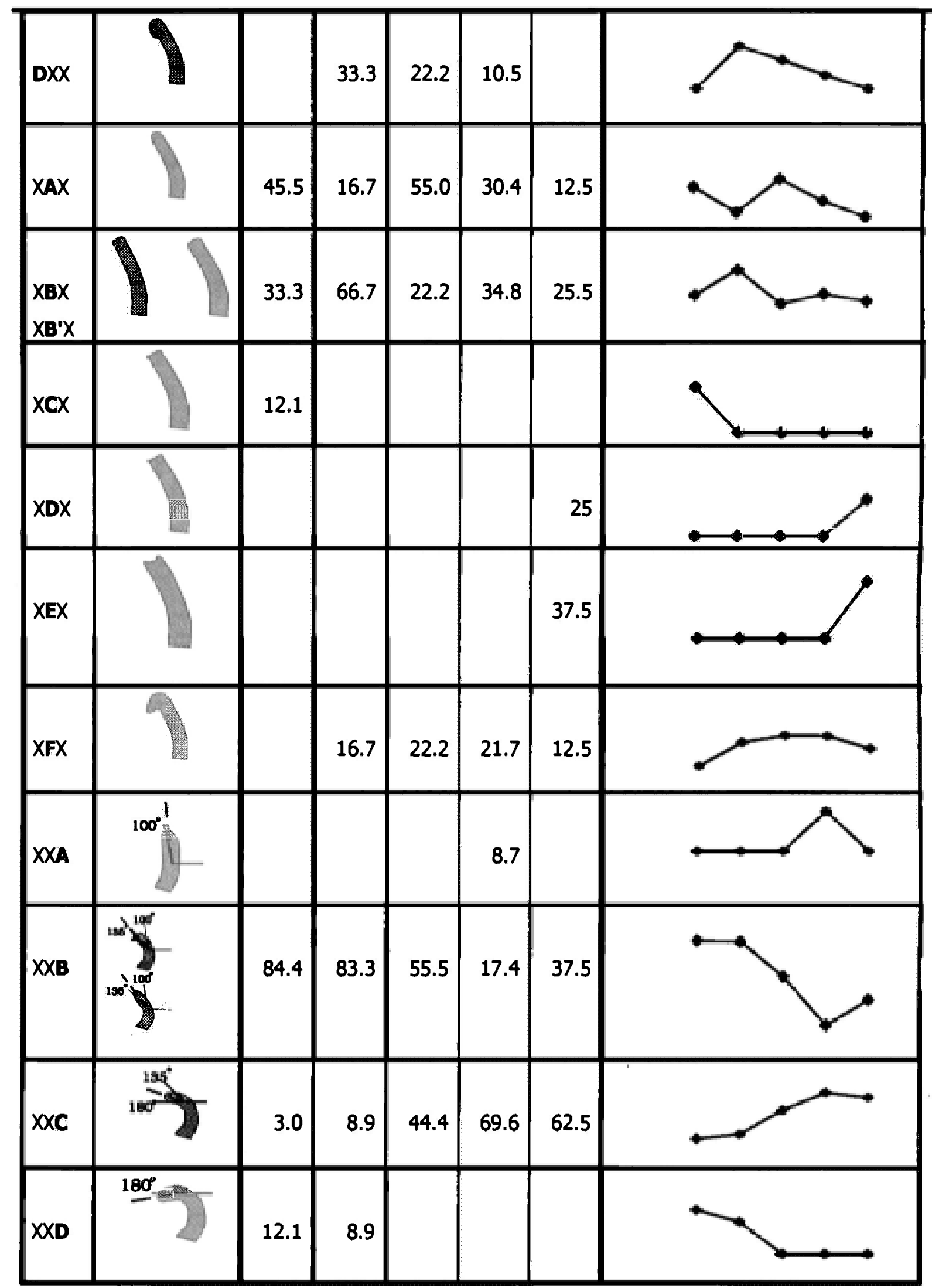


Răsfrângerea mică a buzelor (XXB) caracterizează complexele mai timpurii, iar răsfrângerea pronunţată $(X \times C)$ caracterizează mai mult complexele târzii. Buzele foarte răsfrânte $(X X D)$ sunt nu numai puţine, dar practic şi foarte asemănătoare cu cele de tip $X X C$, echilibrând oarecum graficul anterior.

Tabelu/ 3 prezintă o clasificare a buzelor de vas în concretitudinea lor. În tabel nu figurează toate profilele găsite, variabilitatea fiind foarte mare, ci doar acele specii care sunt caracteristice pentru cel puţin unul dintre complexele martor. După cum se poate vedea, adeseori o specie caracteristică într-un complex lipsește cu totul din celelalte. Tabelul 3 este icoana unei direcţii de cercetare înfundate, diversitatea formelor concrete făcând aproape imposibilă o clasificare şi spulberând tentativele de comparaţie.

TABELUL 3. Profilele cele mai caracteristice

(cumulând factoril de grosime, modelare şi răsfrângere).

\begin{tabular}{|c|c|c|c|c|c|c|c|}
\hline \multicolumn{2}{|c|}{ Specii $(\%)$} & C. 3 & L. 8 & G. 3 & L. 4 & G. 1 & total sit (\%) \\
\hline $\mathrm{AAB}$ & & 11.1 & & 9.1 & & 6.3 & $4.6 \%$ \\
\hline AAC & & & & & 13 & & $2.3 \%$ \\
\hline ABB & & & 16.7 & 6.1 & & & $\begin{array}{l}6.2 \%-\mathrm{AB} \text { 'B (cu o } \\
\text { muchie)- } 1 \text { ex. }(=0.8 \%)\end{array}$ \\
\hline$A B C$ & & 11.1 & & & 17.4 & 6.3 & $\begin{array}{l}4.6 \%-\mathrm{AB}^{\prime} \mathrm{C} \text { (cu } 0 \\
\text { muchie)- } 1 \text { ex. }\end{array}$ \\
\hline AEC & & & & & & 18.8 & $2.3 \%-1$ ex. în "S" \\
\hline AFB & & & & & & 12.5 & $1.5 \%$ \\
\hline BAB & & 11.1 & & 12.2 & & & $9.2 \%-1$ ex. in "S" \\
\hline BBB & & & 25 & 12.2 & & & $\begin{array}{l}12.3 \%-A B^{\prime} B \text { (cu o } \\
\text { muchie)- } 2 \text { ex. }\end{array}$ \\
\hline
\end{tabular}




\begin{tabular}{|c|c|c|c|c|c|c|}
\hline BBC & & & & 13 & 6.3 & $\begin{array}{l}3.8 \%-\mathrm{BB}^{\prime} \mathrm{C} \text { (cu o } \\
\text { muchie) - } 3 \text { ex. }\end{array}$ \\
\hline$B E C$ & & & & & 18.8 & $2.3 \%$ \\
\hline$C A B$ & & & 9.1 & 4.3 & 6.3 & $8.5 \%$ \\
\hline $\mathrm{CDB}$ & & & 3.0 & & 12.5 & $2.3 \%-1$ ex. usor în "S" \\
\hline CFC & 22.2 & & & 4.3 & & $3.1 \%$ \\
\hline DAB & 22.2 & 8.8 & & $4.3^{\prime}$ & & $4.6 \%$ \\
\hline DBB & & 16.7 & & 4.3 & & $2.3 \%$ \\
\hline
\end{tabular}

Notă: Cifrele ingrosate reprezintă prezenta caracteristică intr-unul dintre complexelemartor, celelalte arata prezenta acelulaşi tip în celelalte complexe; în chenar - singura coincidentă de specie caracteristică.

Tabe/ul 4 (infra) strânge date de naturi diferite. Remarcăm întâi o tendinţă de creștere a diametrului la bază, ca şi cresterea diferenţei între cele două diametre.

Calitatea pastei a fost apreciată, pentru fiecare vas (fragment) în parte, cu note de la 5 la 1 , astfel:

5 - foarte bună (numai nisip foarte fin);

4 - bună (nisip cu bobul mare, eventual pietricele mici şi rare);

3 - mediocră (pietricele relativ multe în compoziţie);

2 - slabă (pietricele multe, eventual mai mari de $4 \mathrm{~mm}$. pe una din dimensiuni);

1 - foarte slabă (pietre, impurităţi, frământare insuficientă).

Evoluţia pe complexe poate să nu pară semnificativă, decât dacă nu uităm că sunt medii. Aici ar fi de adăugat că cvasi-totalitatea fragmentelor conţin mică în pastă, mica fiind conţinută în nisipurile locale. Pe unele fragmente se pot observa vinişoare mai întunecate, datorate unui adaos de vegetale în pastă. Deşi am prelevat date referitor la prezenţa vegetalelor în pastă, nu am considerat oportună publicarea datelor, diferenţa dintre "prezent" şi "absent" flind uneori discutabilă. Oricum, pasta cu urme vegetale se întâlnește între o şesime şi o pătrime dintre fragmentele ceramice, urcând până la o treime în G. 1. Aceste vegetale nu sunt în nici un exemplar în cantităţi mari şi nu 


\section{Eugen S. TEODOR}

particularizează aceste exemplare ca ardere, consistență si aspect gểneral. Ar mai fi de remarcat două fragmente nisipoase caolinoide, decorate cu striuri distanțte (fácute cu bătul - în $G$. 3) şi un panou inferior de caolin, nedecorat (in L. 8), precum și câteva fragmente care par să conţină un ocru roz

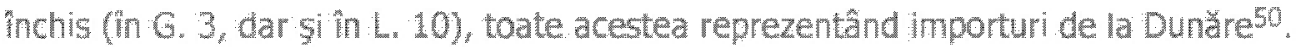

Calitatea arderil a fost notati de la 5 la 1 , dupä cum urmează:

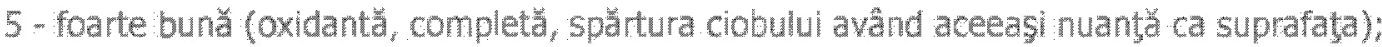

4 - bună (spărtura ciobului este in general cenuşiu-deschis; clobul este sonor la ciocănire);

3 - mediocră (suprafata este coaptă oxidant, dar spărtura este negnicioasă; sonontate slabă, joasă);

2 - slabă (spărtura este neagră, suprafaţa este arsă inegal, pasta este relativ sfărầmicloasă);

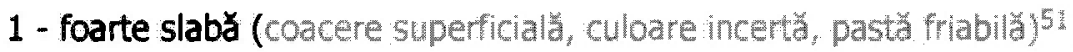

TABELUL 4. Alte caracteristici comparate ale celor cinci complexe-martor

\begin{tabular}{|c|c|c|c|c|c|c|}
\hline $\begin{array}{l}\text { Caracteristica } \\
\text { (medil) }\end{array}$ & G. 3 & L. 8 & C. 3 & 1. 4 & 6. 1 & GRAFICE \\
\hline diametru la buxd $(\mathrm{cm})$ & 16.5 & 17.2 & 17.6 & 17.2 & 19.7 & \\
\hline diametru la bazs $(\mathrm{cm})$ & 12.2 & (12) & 11.3 & 10.4 & 11.4 & \\
\hline raport diametru buzd/bază & 1.35 & 1.43 & 1.56 & 1.66 & 1.73 & \\
\hline $\begin{array}{l}\text { Calitatea pastei (scala 5-1): } \\
\text { de la } 5 \text {-foarte bunz- } \\
\text { la } 1 \text { - foarte proasta } \\
\text { grupa A }\end{array}$ & 3.5 & 3.9 & 4.0 & 3.6 & 3.5 & \\
\hline $\begin{array}{l}\text { calitatea arderii (scalä } 5 \text {-1) } \\
\text { de la } 5 \text { - foarte buna- } \\
\text { la } 1 \text { - foarte proasta } \\
\text { grupa } 8\end{array}$ & 3.3 & 3.7 & 3.5 & 3.6 & 3.9 & \\
\hline $\begin{array}{c}\text { grosimea relativa (scal } 5 \text {-1) } \\
\text { de la } 5 \text { - foarte mica- } \\
\text { la } 1 \text {-foarte mare } \\
\text { grupa A }\end{array}$ & 3.2 & 3.6 & 3.4 & 3.4 & 3.5 & \\
\hline
\end{tabular}

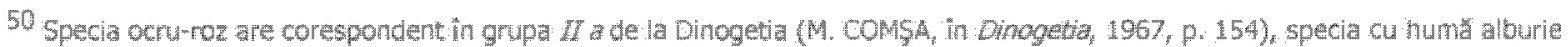

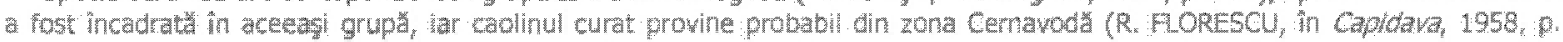

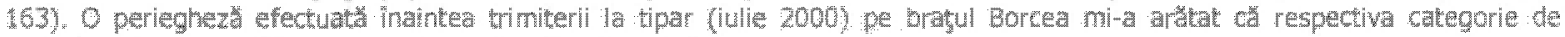
material es

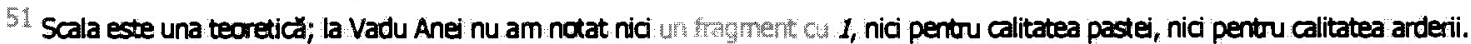




\begin{tabular}{|c|c|c|c|c|c|c|}
\hline $\begin{array}{c}\text { ceramică lustruită din total } \\
\text { ceramică (procente) }\end{array}$ & 9.2 & 8.3 & 36.8 & 17.9 & 0 & \\
\hline $\begin{array}{c}\text { din care (\%): } \\
\text { cenuşie }\end{array}$ & 10 & & 14.3 & 66.7 & & $\begin{array}{c}\text { fară grafice } \\
\text { (baza statistică } \\
\text { foarte redusă) }\end{array}$ \\
\hline cenușiu-negricioasă & 60 & & 28.6 & 22.2 & & \\
\hline gălbui-roșiatică & 20 & & 57.1 & & & \\
\hline galbenă & 10 & 100 & & 11.1 & & \\
\hline
\end{tabular}

Privind graficele, constatăm un fenomen care poate să pară paradoxal, dar care nu are defapt nimic contradictoriu: spre sfârşitul evoluţiei aşezării de la Vadu Anei calitatea pastei este în scădere, dar calitatea arderii vaselor este în progres.

Grosimea relativă a peretelui vasului a fost apreciată pe aceeaşi scală de la 5 la 1, corelând grosimea măsurată la dimensiunile prezumate ale vasului. Astfel, pentru un vas de dimensiuni medii (18 cm. la buză, $25 \mathrm{~cm}$. înălţime probabilă), punctajele sunt următoarele: 5 - $4 \mathrm{~mm} ; 4-6 \mathrm{~mm} ; 3-8$ $\mathrm{mm} ; 2$ - $10 \mathrm{~mm} ; 1$->12 $\mathrm{mm}$. Pentru fragmente de la vase mici sau mari cifrele au fost reevaluate proporţional. Fragmentele notate cu 5 sau cu 2 constituie o raritate pentru grupa ceramică A, însă sunt prezente în toate complexele-martor. Grosimea pereţilor ceramicii din grupa A de la Vadu Anei pare, pe ansamblu, mai mică decât în siturile din zona Bucureștiului sau decât la Dridu.

Ceramica din grupa ceramică B este prea puţină pentru a face ptaservaţii sigure asupra evoluţiilor. Calitatea pastei nu este, în general, cea mai bună, conţinând destul de mult nisip, chiar dacă foarte fin cernut. Arderea este bună, dar nu totdeauna spărtura are aceeaşi nuanţ̧̆ ca suprafaţa, putând fi mai desthisă sau mai închisă. Cel puţin aparent, vasele cenuşii-negricioase sunt din ce în ca: mai puţin preferate, în defavoarea celor cenuşiu-deschis. iar vasele gălbui-roşiatice dispar. Ceramica fină galbenă este prezentă numai prin câteva fragmente mici, dar e de găsit atât în complexe timpurii (G. 3, L. 8), cât şi în cele mai târzii (L. 4) ${ }^{52}$. Repet, ceramica lustruită lipseşte complet din G. 1. Este aici de amintit cazul locuinţei 10, din care s-a recuperat ceramică fină de factură diversificată (PI. 12/f, $g, i, j)$, inclusiv o oală cu ansă, roşie, cu decor lustruit în reţea ${ }^{53}$. Aceste fragmente de oale lustruite reprezintă jumătate din inventarul recuperat al locuinţei, care însă nu a fost săpată decât intr-o proporţie de aproximativ o pătrime (PI. 5).

Încercările de a pune în evidenţ̆ asocieri preferenţiale între anume tipuri de buze şi anume specii de decor nu a ptodus rezultate notabile, cu excepţia asocierii buză şănţuită - deccor în "ochi", pentru G. 1. Aceste vase dau de altfel particularitate complexului, care, prin inventarul său ceramic, este interesant şi poate da unele indicaţii asupra limitei ante-quem a aşezării. Ceramica din G. 1 se mai distinge prin faptul că este lucrată pe o roată mal bună; într-un caz, chiar, se văd urmele sforii cu care a fost desprins vasul de pe roată. Fundurile vaselor sunt mai subţiri şi tind să se arcuiasç̆ (PI. 12/p, $q, s, 9 / s)$, subzistând însă, ca

\footnotetext{
52 Caracteristicile Inventarului din L. 4 amintesc complexele de la Şendreni, datate la sfârşitul primei treimi a sec. X]: borcane din grupa A cu buza răsfrántă, umeri înalţ, cu fund îngust, cu ștampile puţine; cerarnică din grupa B cenuşie, fragmente gălbui, dar nu şi roşii/roz (D. GH. TEODOR, Danubius, I, 1967, p. 129-135).

53 Structurarea inventarului din B.10 evocă L. 1 de la Băneasa-Sat (M. CONSTANTINIU, P. I. PANAT, CAB, II, 1965, p. 98 şi următoarele), unde mai mult de o treime din inventar este reprezentat de cerarnică lustruită, din care majoritatea rnşie, cu şi fără anse. Astfel de situaţi sunt interesante mai ales prin prisma absentei ceramicii lustruite roşii in situl de la Oridu. Acesta ar fi un argument în favoarea datării sitului eponim al culturii cel mai tárziu până la sfárşitul sec. al X-lea. În periegheza amintita şi la nota 50 am găsit un vas intreg, cu morfologia tipică a unui vas cenuşiu lustruit (cu două anse), realizat insă din pastă nisjpoasă (färă caolin), cu ardere oxidantă. După știnta mea acest vas este deocamdată unicat șj este important findcă descrie degradarea speciei "de lux".
} 
excepţie, exemplàre cu aspect primitiv (PI. 12/ $)$. Mărcile de olar lipsesc în G. 1.0 altă particularitate o reprezintă cele două fragmente de caștron (PL. $9 / r$ şi s), formă inexistentă în celelalte complext.. Fragmentul de la Pl. 9/r a are o analogie foarte bună la Păcuiul lui Soare ${ }^{54}$, unde apartine grupei II d (jumătatea sec. al XI-lea), în timp ce profilul recurbat al fragmentului de la PI. 9/s poate sugera înrudiri cu grupa II c (cu aceeași datare) ${ }^{55}$. Analogii morfologice se pot găsi şi ła Dinogeţia ${ }^{56}$. Toate caracteristicile enunţate recomandă o datare târzie şi puţin obişnuită în Câmpia Română, în secolul XI, probabil la jumătatea acesturia 57 . O aseınenea datare nu ar trebui să contrarieze, fiındcă ru contrazice părerea unanim acceptătă a diluării factorului băştinaş în câmpia de la nordul Dunării, în secolul respectiv ${ }^{58}$. Din contră, 0 confirmă. Un singur alt complex pare să fie contemporan cu G. 1. Este vorba despre L. 5, locuinţă de suprafaţă, care, cum am mai spus, a fost cercetată parţial, din motve independente de voinţa colectivului de arheologi. De pe chirpicul ars al acesteia s-a recuperat un fragment (PI. 9/n) care nu are analogii apropiate decât în inventarul G. 1 (compară cu Pl. 9/f) respectiv profilul şi decorul principal, benzi striate sinusoide suprapuse, formând "ochi"; elementul decorativ secundar, bantla împlebtă, are analogii - rare - şi în alte complexe (PI. $9 / q$, respectiv din L. 4). Un fragment ceramic asemănñtor s-a găsit în stratul arheologic din caseta V A, deci între cele două complexe (L. 5, pe S. XVI b şi G. 1, în caseta V B, vezi planul general de la PI. 1), ceea ce contureuză ipoteza că flancul nordic al aşezării a fost ocupat cel mai târziu. $O$ altă piesă ceramică din complex (PI. 9/J) ilustrează unul din aspectele din complexele considerate aici ca târzii, piesă cu profil neobişnuit (diametuul la gură este aproape egal cu diametrul maxim) şi cu un element ornamentic rar, pentru această perioadă - alveolele pe gât, compoziţie a pastei grosolană, toate elemente de caracterizare primitivă, prohabil o influentă răsăriteană resentă. Este un fapt constatat pe mai multe şantiere pilot ale epocii ${ }^{59}$, că în etapa finală de evolutie a culturii Dridu (care poate fi numită, începând cu secolul XI - post-Dridu) unele elemente morfologice şi decorative le continuă pe ccle anterioare, chiar pe o linie ascendentă, dar, în paralel, pătuund elementie disonante, cu aspect şi tehnologie primitive.

Cu titlu de probabilitate se poate include în categoria complexelor din ultima generaţie și G. 2 , pentru care pledează doar factura generală a pastei şi arderii.

Celelalte complexe-martor (G. 3, L. 8, C. 3, L. 4) au multe în comun: ceramică fină-lustruită puţină, câteva mărci de olar (una în G. 3 şi două în L. 4, v. PI. 12/k, l, m), un spectru ornamental comun, profile de buză asemănătoare. Există însă şi lucruri pe care statistica nu le potea surprinde. Buzele cu profil întors în formă de "cioc" (nefiind vorba despre cioc de turnare, fireşte!) din perioada mai timpurie (PI. 10/c,j, ) îşi relevă provenienţa din buza întoarsă şi lipită "colac"60 (ilustrată la PI. 10/d). Aceleaşi buze, în complexele mai târzii, sunt arcuite mai larg (PI. $9 / g, j, m, 0$ ). Capătul acestei evoluţii se întâlnește în G. 1, cu buza trasă drept spre afară, sub un unghi de $45^{\circ}-55^{\circ}$ (PI. 9/a, $b, \sigma$ ). Şi alte detalii, prezentate pe larg mai sus, indică o factură mai evoluată a inventarului din L. 4, deci 0

\footnotetext{
54 R. HARHOIU, în Pácuiul lui Soare, J, 1972, figura 28/13.

55 idem, figura 28/7, 9.

56 R. FORESCU, in Capidava, 1958, figura 111/3, castron din grupa IV a.

57 Nu este insă prima oară când se face o, datare la jumătatea sec. $\chi$ pentu acest areal geografic (GH. MANUCU ADAMESTEANU, $C A B$, IV, p. 6474 - puţin probabil pentru Băneasa-Sat). Ceea ce nu inseamnă că această datare este sigură. Deocamdată discutăm în termeni conjuncturali şi nu se zăreşte capătul tunelului.

58 Pentru contextul istoric şi arheologic al epocii, P. DIACONU - Les Petchéneques au Bas-Danube, Bucuresti, 1970; idem - Les Coumans au Bas-Danube, Bucuresti, 1978.

59 de exemplu P. Diaconu...... Păcuiul lui Soare, I; ....Dinogetia; passim.

60 M. CONSTANTINIU, P. I. PANATT, CAB, II, 1965, p. 134, denumesc această buză a cărul profil se intoarce ca un cioc de pasăre - buzd "melc"I. Termenul ar putea fi bun, daç̆ ar fi şi sugestiv. Oricum, autorii împărășesc ideea că buza "melc" provine din cea intoarsă și lipită "colac". În privinţa terminologiei, in locul căutării sterile a unor metafore fericite, as prefera exprestile aride, dar neduplicitare, de genul "buzz̆ tip XFX". Condiţa este insă, din nou, existenţa unui cod recunoscut de toată lumea.
} 
datare mai târzie. Aplicarea mai multor valuri pe umăr, uneori foarte late, coborând până sub diametrul maxim (PI. 11/b, $c, h$, $)$ ilustrează la complexele din zona sudică a şantierului (G. 3, L. 8, C. 3) o legătură cu tradiţii de la începuturile culturii Dridu, iar unele profile sugerează ceramica slavă arhaică (de ex. Pl. 11/h). Asemenea exemplare sunt doar nişte reminiscente, de altfel rare, dar sugerează datarea mai timpurie a acestor complexe.

Cum se pot plasa, în cronologie relativă, celelalte complexe? Fireste, cu cât inventarul este mai sărac, cu atât se limitează posibilităţile de apreciere. Cele patru locuinţe de pe S.XXVIII a (PI. 5) ar putea fi interpretate, prin chiar alinierea lor, ca fiind sunt strict contemporane. Pe material, însă, este mai greu de admis. În L. 7, săpată aproape integral, nua fost găsită ceramică din grupa B, situaţie ce o aseamănă cu locuiaţa cea mai apropiată, L. 8. În celalte două locuinţe de pe S.XOVIII $a$, dinspre NE (L. 9 şi L. 10), în schimb, există ceramică lustruită, dar cele două complexe nu sunt săpate complet şi nu se pot preciza proporţile. Mai mult, din L. 7 provine un fragment ceramic ce, prin profil şi prin decor (scurte linii orizontale trase cu dinţii pieptănului, v. PI. 15/m) arată similitudini cu fragmente ceramice considerate până aici ca fiind mai târzii. Nu ne putem aștepta însă ca realităţile de pe teren să fie perfect coerente, necontradictorii.

În fine, mai sunt complexele cu foarte puţin inventar. Cele două fragmente ceramice găsite în cuptorul Locuinţei 6, prin compoziţia mai fină a pastei şi prin grija cp care a fost trasat decorul (PI. $11 / n, o$ ) sunt singurele care sugerează contemporaneitatea cu ceramica de la Dridu ${ }^{61}$. Această observaţie ar putea fi eventual extinsă asupra celor două vase fragmentare recuperate din cuptorul metalurgic (C. 4, v. PI. 11/d, f). Despre încadrarea cronologică a cuptorului de pâine (C. 2) nu se poate spune nimic, având un singur fragment ceramic mai mare (PI. 11// - decorat cu val pe umăr) care, în afară de faptul că e cam grosier, nu are elemente specifice.

\section{ASEZAREA DE TIP DRIDU. CONCLUZII.}

Pe terasa stângă a râului Pasărea, în dreptul actualei acumulări Pasărea 5, a evoluat timp de câteva generaţir $o$ aşezare aparţınând perioadei finale a culturii Dridu. Aşezarea este mai mare decât limitele şantierului de salvare, continuând către sud, spre satul Vadu Anei. Complexele mai târzii se grupează în sectorul A (de nord), iar complexele mai timpurii se grupează în sectorul B (de sud - vezi planul general). În extremitatea de sud a şantierului, pe S. XXXII, în strat, a fost găsit singurul fragment ceramic decorat pe buză (PI. 11/r), tip ceramic destul de frecvent la Dridu.

Aşezarea este de tip pendul, fapt demonstrat cel puţin de două situaţii: conservarea $C$. 2 în vederea reutilizării; veriga lipsă, la nivelul evoluţiei culturale, între L. 4 şi G. 1. Locuinţele sunt cele de tip obişnuit: semi-îngropate, cu "pari de colţ" pe o singură latură, farăl arnenajări observabile ale podelei şi pereţilor "bordeiului", cu un cuptor cotlonit (cu horn) în colţul cruţat, la nord. A existat, probabil, o fază târzie, cu locuinţe de suprafaţa (L. 5). Cuptorul metalurgic (C. 4), groapa cu reziduuri ale unui al doilea cuptor precum şi reziduuri de la prelucrarea secundară (C. 3), buç̆ţile mari de zgură şi pietrele de calcar din L. 7, atestă o preocupare metalurgică destul de substanţială. Prin contrast, descoperirile de metal prelucrat sunt extrem de sărace, reducându-se la un vârf de săgeată, un vârf

\footnotetext{
61 Umărul puternic conturat face trimitere la faza a II-a a sitului de la Dridu. Această caracteristică morfologică a facut ca desenatorul - începător fiind - să reprezinte fragmentele ceramice în perspectivă orizontală, corectă in principiu, dar prea în racursi pentru cazul dat. Rezultatul este că o bandă în val trasată ordonat să fie aproape de nerecunoscut intr-un desen principial corect. Ideal ar fi ca, in astfel de situagli, decorul să fie reprezentat în desfașurare plană. Nu există insă norme sau convenţi general cunoscute sau recunoscute. Comisia Arheologică ar trebui să-şi manifeste autoritatea şi competenţa şi in această direcţie, o dată cu o necesard tentativă de asanare şi regularizare a limbajului descriptiv.
} 
de cuţit, câteva cuie şi, ca mărturie indirectă, un fragment de plăsele. Faptul probează două lucruri: diferitele etape de locuire s-au încheiat paşnic şi ordonat (poate cu excepţia ultimei etape, L. 5 fiind arsă), fiind strânse toate obiectele folositoare; fierul era o materie scumpă (sau pur şi simplu greu de procurat, ca minereu sau obiect prelucrat), piesele vechi sau fragmentare fiind recuperate şi retoplte.

Având în vedere numărul de locuinţe descoplerite (7) şi procentul cercetării efective a suprafeţei locuirii Dridu (12\%), estimez numărul total de locuinţe dridoide, în suprafaţa cercetată, la circa 60. Acest număr ipotetic se împarte probabil la patru generaţii diferite, astfel că o comunitate de acest tip atingea 12-15 "fumuri". Aceste evaluări rămân foarte aproximative, câtă vreme nu ştimn nimic concret despre terenul de la sud de S. XOXII. În principiu, însă, numărul poate creşte.

Această comunitate era nu numai mică, dar şi foarte izolată. În afara câtorva fragmente de ceramică nisipoasă mai îngrijit lucrată, fără mică, probabil de import (de ex. PI. 10/b, PI. 9/g), trei fragmente de caolin şi două fragmente cu colorant roz, provenite cu siguranţă de la Dunăre, lipsesc orice dovezi ale legăturilor cu exteriorul. Nu s-a găsit marfă de origine bizantină, dar nici atât de frecventele "căldări pecenege". Dispunerea geografič̆, relativ departe de marile râuri (Ialomiţa, Argeş) se pare că a favorizat o autarhie sporită.

A încerca o încadrare cronologică pentru un sit ca cel de la Vadu Anei este o construcţie pe nisip, atâta vreme rât cronologia marilor situri este încă obiect de dispută şi în mişcare ${ }^{62}$. Ar fi de discutat chiar sincronismul cetăţilor de la Dunăre, atât între ele, cât şi în relaţie cu aşezările din Muntenia. Altfel spus: legăturile sunt suficient de strânse pentru a crea un spaţiu cultural unitar, cu trăsături comparabile? Pentru a da numai un exemplu: ce semnificaţie are prezenţa decorului cu rotiţa la Dunăre şi raritatea acestuia în câmpia nord-dunăreană63, şi în ce măsură faptul poate avea consecinţe asupra putinţei de a compara, implicit asupra judecăţilor cronologice?

În aceste condiţii, pot afirma dear că, probabil, situl îşi începe existenţa în perioada finală a sitului de la Dridu şi îşi încetează existenţa înainte de nivelul al III-lea de la Păcui, care este evident altceva. Limitele cronologice relative ar fi înitre ultimul sfert al secolului al $X$-lea şi jumătatea secolului următor.

Informaţiile pe care le deţin despre ceramica de tip Dridu, inclusiv cea de la Vadu Anei, sunt punctate de numeroase contradicții, pe care nu ar fi locul să încerc a le soluţiona, sau motiva, într-o lucrare ce nu şi-a propus astfel de ambiţii. Nu am fácut aici decât să ofer o bază de date, fie şi parţială, cane să dea cercetătorului mai cutezător Iun punct de sprijin în plus. Închei aici, punând đe-o parte contradicţile şi aşezând cap la cap câteva lucruri care se pot afirma, cu oarecare siguranţă, despre evoluţiile ceramicii Dridu în Câmpia Română, mai ales în a doua parte a istoriei sale, slujindumă şi de informaţia tocmai achiżţionată la Vadu Amei:

\footnotetext{
62 Petre DIACONU a contestat cronologia propusă de autorul sitului de la Bucov (M.COMŞA - Cultura veche materială românească..., 1978), propunând secolele XII-XIII in loc de VIII-X (SCIV 30, 1979, 3, recenzie). Acelaşi cercetător consideră că aşezarea de la Dridu şi-a incetat apariţa cel mai târziu la sfárşitul secolului al X-lea. În ce priveşte Dinogetia, care este situl cu stratigrafia cea mai complexă pentru epocă, datarea monedelor înseşi este pusă în discuţe.

63 Accidental, specia apare şi in cámpie, de pildă la Băneasa-Sat (M. CONSTANTINIU, P. I. PANAT, CAB, II, 1965, p. 98 şi urm.), unde decorul cu rotiţa era aplicat pe un ciob cu "pastă bună, roşie", ceea ce face trimitere la grupa a IV-a de la Dinogetia (M. COMŞA, in Dinogetia, p. 170-174).
} 


\section{Grupa A}

- Pasta este la început nisipoasă, aspră la pipăit; ulterior se adaugă şi alţi ingredienţi: pietricele (sau calcar pisat), cioburi pisate ${ }^{64}$, pleavă, chiar scoici pisate (secolul XI).

- Arderea este în mod tradiţional oxidantă, dar incompletă, cu miez cenuşiu-negricios; izolat, pentru unele situri, se înregisttează o ardere mai bună65; pe ansamblu, se înregistrează un progres lent.

- Roata este şi ea tot mai bună - sau este mai bine folosită; spre final apare roata de picior $^{66}$, cu inconfundabilele semne de pe fundul vasului, dar nu se generalizează, încă; în consecinţă, pereţii vaselor devin mai subţiri (5 mm.).

- Semnele de olar, cunoscute şi mai devreme, devin frecvente (15-20\%) în special în a doua jumătate a sec. $X$; obiceiul ştampilării vaselor cu aşa-numitele "mărci" intră în declin în secolul XI67.

- Buza vaselor evoluează, principial, de la simplu la complex: de la buze rotunjite şi făţuite (teşite - sec. IX) spre buze îngroşate sau întoarse şi lipite ("colac" sau "melc" - sec.X); apoi buzele se fac mai evazate şi apar şănţuiri fie pe cantul buzei (ca la Vadu Anei) sau pe exteriorul ei (ca la Şendreni - prima jumate a sec. XI ${ }^{68}$ ); în finalul acestei tendinte de ridicare, buza este întâi evazată apoi trasă spre înăuntru, "în formă de S" (Păcui, a doua jumate sec. XI), formă ce va fi transmisă evului mediu dezvoltat.

- În privinţa proportiilor generale, evoluţia este de la valori apropiate între diametrele la gât şi la bază - spre o disproporţie tot mai accentuată, fundul fiind din ce în ce mai îngust; vasul crește uşor în înălţime, iar diametrul maxim se plasează tot mai sus.

- Unealta de decor cea mai tipică este pieptenul; spre sfârşit, mai ales, se utilizează şi băţull, cuţitul şi altele

- Decoru/ întâlnit în toată perioada este striul orizontal pe tot corpul, fiind mai tipic în perioada de început.

- Foarte des apare o a dova temă decorativă, la început mai ales alăturată striurilor orizontale, apoi suprapusă; cel mai frecvent această a doua temă este valul.

- Pattern-ul decorativ cel mai obişnuit la început este alternanţa valuri - orizontale; apoi orizontalele din zona superioară dispar, lăsând loc la mai multe rânduri de valuri, distanţate, pentru ca, în secolul $X$, să rămână un singur val, urmat de striuri orizontale, combinaţia "clasică" la Dridu.

- Spre sfârşitul sec. X se remarcă o tendintă "baroc", atât prin aglomerarea decorului, cât şi prin angajarea tot mai frecventă a altor teme decorative, chiar ca al treilea

\footnotetext{
64 Cioburile pisate sunt o constantă in Moldova, începând cu secolul VI (D. GH. TEODOR - Teritoriul est-carpatic in secolele V-XX, Iaşi, 1978, p. 80 şi următoarele; idem, SCN, 19, 1968, 2, p. 241 şi următoarele), reprezenténd jumătate din ceramica secolelor IX-X].

65 De exemplu Bucureşti-Noi, sector Alba (P. I. PANAT, CAB, I, 1963, p. 125).

66 Sunt extrem de rare siturile in care ceramica fucrată la roată rapidă formează majoritatea (Şima-Prahova - ŞT. OLTEANU, V. TEODORESCU, N. NEAGU, MCA, XIII, 1979) sau un lot semnificativ (Bucov - M. COMŞA, 1978), alăturare ce sugerează că Muntenia subcarpatică prezintă particularităţi notabile, care nu permit translări mecanice. Din păcate, arealul este prea puţin cunoscut.

67 Sporadic, mărcile de olar se intâlnesc, in Dobrogea, până in secolul XII (P. DIACONU, Păcuiul /ui Soare, I, 1972, p. 132).

68 D. GH. TEODOR, Danubius, I, 1967.
} 
element, supra-pus (fascii, frize de împunsătự oḅlice, alveole pe umarr); la Dunăre apare un element străin - ratiţa, care tinde să înlocuiască striül cu pieptenul, element care, izolat, poate fi găsit şi în câmpie.

- în secoluI XI se accentuează tendintele de dezorganizare şi trasare neglijentă, iar, pe linia Dunării, o descongestionare a spaţiului, calitatea decorului rămânând şi aici scăzută69.

Grupa B - mai bine reprezentată în secolul X.

- Pasta este de bună calitate, cu nisip puţin şi fin, cu ardere reductoare, evoluţie de la gri-negricios la gri-deschis.

- Forma tipică este globular-alungită, cu gât scurt, pe o bază lată, cu buze subţiate sau întoarse "colac", cu pereţi groşi; apar şi variante cu anse groase, aplatizate, scurte, pe gât-umăr.

- Ceramica arsă reductor este de obicei decorată numai pe partea superioară, în reţea, decor mărginit pe (sub) diametrul maxim de caneluri orizontale, pattern cunoscut de la început.

- Pentru sec. (IX-)X, alături de reţeaua rombică, apar "tabla de şah" şi liniile verticale (oblice - "poaie"). La sfârşitul secolului $X$ tema decorativă în retea rombică devine iarăşi dominantă 70 .

- În a doua parte a sec. $X$ este atestată şi o variantă arsă oxidant (gălbui-roşiatic) ${ }^{71}$.

- Uicioarele galbene sunt foarte rare, dar au o cronologie largă.

- Grupa ceramicii fine intră în declin spre sfârşitul sec. $X$, dar probabil a mai fost produsă în unele areale 72 .

69 Tema decorativă preferentjală în etapa mai târzie de la Vadu Anei (in G. 1) o constrtuie, cum am văzut, valurile intuetăiate în "ochi", ceea ce ar consuna cu veritabila obsesie decorativă de la Bucov. A considera acest sit ca fiind de secol Xal nu rezolvă insă problemele, ci le muta. Pentru a exemplifica, buza decorata, care mai apare la Vadu Anei pe un singur fragment, la Bucov este iarăşi frecventă (ca la Dridu). Pe de altă parte, specia decorativă in "ochi" ( $k$ ) este bine reprezentată, într-o variantă putin diferită, la Dulceanca IV, datată la sfârşitul sec. VI (S. DOUNESCU-FERCHE, Dacia N.S., XOXVI,1992). Chiar daca datarea acestui din urmă sit ar fi mutată in secolul VIII, lucrurile rămân confuze, iar reminescentele ceramicii lucrate cu mâna exclud o datare mai tårzie (la Dulceanca). Dezideratul construirii unor puncte de plecare convingătoare pentru cronologia relativă a culturii Dridu rămâne, deocamdată, un obiectiv prea indepărtat. Cel puţin cu mijloace clasice.

70 Concluzia se desprinde din mai multe situri (R. RORESCU, in Capidava, p. 171; E. ZAHARIA, ...Dridu, p. 85; Vadu Anei, supra, tabel 1), dar la păcui, a căror nivele medievale umpurii se datează exclusiv în sec. $X$, nu s-au găsit decát cáteva fragmente, decorate numai cu linii paralele oblice, färă reţea (R. HARHOIU, în Pacuiul lui Soare, p. 85. Este un caz clar de evoluţie asincrona.

71 Această specie lipseste nu numal la Dridu (secolul $X$ ), dar şi în cimitirul de la Castelu, datat în a doua jumătate a secolului al IX-lea şi în prima jumătate a sec. X (A. RADULESCU, N. HARţUCHI - Cimitiru/ feudal-timpuriu de la Caste/u, Constanta, 1967).

72 Prezentă înç în cantităţ sporite în ultima fază de evoluţie a culturii Dridu in Moldova, numită de D. GH. TEODOR (SCMA., 19, 1968, 2) "faza Şendreni" (Şendreni-Galaţ, Cárja-Bârlad, Pojorăni-Bârlad ş.a.), cât și la Bucov, dacă admitem o datare mai tárzle pentru acest ultim slt. 
The paper is referring to the rescue diggings made North of Vadu Anei village by a large team from National Museum of History during 1991-1993. The site is on the Bucharest-Constantza highway, on $12^{\text {th }}$ kilometer. On have been recovered archaeological remains from Neolithic, Bronze Age (both sporadically), from classic Dacian rural civilization, Early Middle Age, a settlement and a cemetery from Late Romanian Middle Age. The paper is reporting here only the settlements from early VII ${ }^{\text {th }}$ century and from late $X^{\text {th }}$ - early $\mathrm{XI}^{\text {th }}$ centuries.

Beginning with a general outstanding of the diggings (Plate 1), the report is going on wim the description of the four habitation items, three earth-huts (B.1, B.2, B.3-plates 2-3) and one oven $(C .1)$ - this one, probably, belonging to another hut. Dealing with short dead lines, the team had no time to uncover completely those items. It is possible, yet, to draw basic things about the way those houses were made. One was digging a hole - with no very regular shape - about $12-15 \mathrm{~m}^{2}$ and about $0,7 \mathrm{~m}$. deep. About one square meter, in the northern corner, it has been dug only to the clay layer. In this block of clay one was hallowed the interior shape of the oven, beginning with the upper part, and the access hole. On the top it was add a cylindrical and short chimney-like, with prepared clay. This kind of oven - very well known in The Romanian Plain, named, not very proper, oven with chimney - was functionally completed by a large clay tray, standing on the "chimney" and controllirig, this way, the air stream. The house, itself, had no chimney, but a window in the roof, for driving out the smoke. The pit of the hut presents no traces of fitting out and, usually, any traces from the struetural pillars. It is: obvious that the pit's edges does not match with the hut's walls, that should be found outside the pit. Concluding, the hut's pit has to be understood like the "kitchen"; the "bedroom" is to the outside ground level (or higher).

The inventory of the huts is poor and reduced almost to the pot's sherds. All ceramic is handmade, with one exception - a slow-wheel made pot. The pottery past is rough, containing sometimes sherd-pound (up to $3 \mathrm{~mm}$. in size), but the modeling is faire. The burning is oxidant, but not complete and not equal. The rest of the inventory is made by clay supports, egg-shaped or cylindrical (PI. 8/e), fragments from a tray, little pieces of slag (but not metal objects). Sites with this kind of inventory are not usual in The Romanian Plain, but in the last six years were reported two other cases (Şuviţa Hotarului - Cãlãraşi county and Viıdu Codrii - Olt county, on Olt-river right side). Together with Vadu Anei, those sites seem to represent the final stage for Ipotesti-Cândesti culture, in the last years of roman limes (590-615, possibly later). This cultural facies is now first time defined as Vadu Anei cultural facies. This is the polnt of minimum for the Northern-Danube society in its whole history; a contraction for its strength, economy, technology and demography. This involution, next to the disappearance, it is due to the avaro-slavic migrations.

The temptation for a slavic attribution, absolutely normal in the context of last half century research, is to be taken with precautions. The slip of diluted clay applied on the pottery, the morphology of the pots, the continuity of the hut fitting (especially the oven), the size of pots (somewhere to the helf of usual slavic pot's volume- see E. S. Teedor in Arheologia Medievalã 2, 1998), the absence of "slavic" tray, the absence of weapons, all these are heavy arguments for precaution. 
In what is concerning the settlement depending from Dridu culture, this is bigger, more dens, and much more usual with the similar.settlements from the end of the first millenium. There are six huts (plates 3-5), one surface burned cottage, two bread-ovens (plate 7), one iron furnace and another one deduced from one slag-pit (plate 6). The huts are extremely similar with those from VII ${ }^{\text {th }}$ Century, including the oven fitting. As a difference - it is possible to find, sometimes, pillar negatives on one side of the hut's pit. A special note is to be done for the iron furnace. This kind of furnace is pretty rare for the early middle age in Romania, but this rectangular-shaped is unique, as far as I know. The both, shape and utility, are yet above the doubt.

This settlement is to be dated in the last third of $X^{\text {th }}$ century and in the early XI ${ }^{\text {th }}$ Century, on the latest stage of Dridu culture. The chronology proposed is based entirely on ceramic study and through analogies with other sites. This is why the description of pottery takes a meariingful part of the report. The four tables, in the end of the paper, could be helpful for the foreign reader. There are chosen five habitation items, the most representative as inventory (G.3, L.8, C.3, L.4 and G.1), arranged as a supposed and hypothetical chronological order.

The conclusions possible today are far to be positive and historically relevant. The statistic studies on this field are only in the beginning. Although, one could note that the population is diminishing for the end of the interval, on are choosing temporary surface cottages, the fine polished pottery disappear, also the imports. For the sandy pottery is to observe that the wheel is better used, the burning is improving, but the decoration is getting worse. For the part, these could be the results of Coumans migration. The final result is a real terra deserta for the dext two centuries, in the Romanian Plain.

Tables explanation:

Table 1: Decoration patterns for Dridu culture in five habitation items from Vadu Anei (percents).

Table 2: Rim classification depending thickness (OXX), modeling (XOX) and angle (XXO); same horizon (analytical view).

Table 3: Most usual rim-shape (bold figures for oha of the first three shapes in the complex; percents).

Table 4: General data for the elected five items (averages). From up to down: rim diameter; bottom diameter; report rim/bottom diameters; paste quality (from 5=best; 1 =worst); burning quality (same scale); relative thickness (5=thin) for sandy $(=\dot{A})$ type; fine polished $(=8)$ type, percent; the same - gray; the same - dark gray; the same - reddish; the same yellow.

Plates explanation:

PLATE 1: General outdrawing of the diggings. In frame - cemelery area (XVI ${ }^{\text {th }}$ Century AD); there one can see only the sections made in 1991. For details - see the cemetery report (stand by). The up-narrowed triangles are pointing the VII ${ }^{\text {th }}$ Century complexes; the downnarrowed triangles are pointing the positions of the Dridu culture ( $\mathrm{X}^{\text {th }}-\mathrm{XI}^{\text {th }}$ Centuries). The white triangles means remains from Dridu culture, without recovered complexes in the area. 
Dridu settlement is more extensive than the rescue area, going South down to the Vadu Anei village. Left (down): conventional patterns for drawings.

PLATE 2: Earth huts (further: hut; noted "L.") from early VII ${ }^{\text {th }}$ Century; (a) draw for the hut L.1, with two constructive stages; (b) draw and section for the oven from the hut $L .1$; (c) draw and section for the hut L.Z, (d) section for the oven from the hut L.Z.

PLATE 3: The hut L.3 (VII ${ }^{\text {th }} \mathrm{C}$ ): (a) plan; section for the oven (b) and photo for the same (c); the hut $4\left(X^{\text {th }} \mathrm{C}\right)$ - research stade before destruction

PLATE 4: Huts from $X^{\text {th }}$ Century. Draw for hut $L .6(a)$ and section for the hut's oven (b); draw (c), section (d) and photo (e) for the oven from the hut L.8. For the hut $L .8$ see also next plate.

PLATE 5: Section DOVIIIa (partial view). Medieval earth huts from several different times: VII ${ }^{\text {th }}$ Century (L.3), $\mathrm{X}^{\text {th }}$ Centuries $(L .7, L .8, L .9, L .19)$ and one from the late Romanian Middle Age $\left(\mathrm{XVI}^{\text {th }}\right.$ Century)

PLATE 6: Metallurgical complexes $\left(X^{\text {th }} C\right)$ : bread oven (C.J) turned to slag-pit (a); iron furnace (C.4) and the slag-pit (b); section through the fumace $C .4$; reconstruction $C .4-$ section (d)

PLATE 7: Bread oven (C.2, $X^{\text {th }}$ Century): draw (a), cross sections (b) and photo for Eastern quarter (c). Pits (?) for domestic thrash ( $X^{\text {th }}$ C): Gr.3 (S.XXXIII, \#13-14) (d) and Gr.2 (S.XV, \#1-2) (e) - sections.

PLATE 8: Pottery from the early VII ${ }^{\text {th }}$ Century: hand-made from $L .3(a-d, k-n), L .2(i-j, 0-s), C .1$ (oven, probably inside a hut $-t-v$ ); only one pot slow-wheel-made from $L .3$ and a claysupport from the same hut. Vertical lines are marking the radius.

PLATE 9: Dridu pottery ( $X^{\text {th }}$ Century, lately first half of XI ${ }^{\text {th }}$ Century), sandy type, from pits Gr.1 (a-g) and $G r .3(r-s)$, huts $L .5(h-j)$ and $L .4(k-g)$; bone knife-handle from hut $L .7(t)$.

PLATE 10: Dridu pottery, sandy type, from huts $L .8(a-j), L .9(k-s), L .10(t, u)$; decorated sherds Greek symbols.

PLATE 11: Dridu pottery, sandy type from $G .3(a-c, p, q), C .4(d, f), C .3(g-i), C .2(1), L .6(n, 0)$; decorated rim from the layer $(r)$; polishing stones from $C .3(j, k)$; air pipe for furnace $(C .4)$.

PLATE 12: Fine polished pottery, red $(b, g, i)$ or gray $(a, c-f, j)$, from $G .3(a-d), L .4(e, h), L .10(f, g$, $\mathrm{i}$, j). Bottoms, sandy pottery, from $L .4(\mathrm{l}, \mathrm{m}, \mathrm{p}, \mathrm{q}), G .3(\mathrm{k}, \mathrm{n}, 0), G .1(\mathrm{r}, \mathrm{s}), L .8(\mathrm{t}-\mathrm{v}), L .7(\mathrm{z})$.

PLATE 13: Morphological data for pottery from the beginning of $\mathrm{VII}^{\text {th }}$ Century. Hand-made pots (except VIII/o, see Plate VIII, figure 0 ). For data significance - see Eugen S. Teodor Sistemul Compas..., Bucuresti 1996. On Mrf column - * means bottom diameters; the others - rim diameters. Shorts: $V A=$ Vadu Anei; compl. = completed shapes; imcom. = all fragmentary shapes; toate = all pots (completed or not); Suvita Hot. = site Casscioarele Şuvita Hotarului; Vadu Codrii = site Piatra Olt - Vadu Codrii; Nas/ac clm. = site Noşlac, only hand-made pottery; italic font = pottery slow-wheel-made; for bibliography - see Romanian text and notes. 


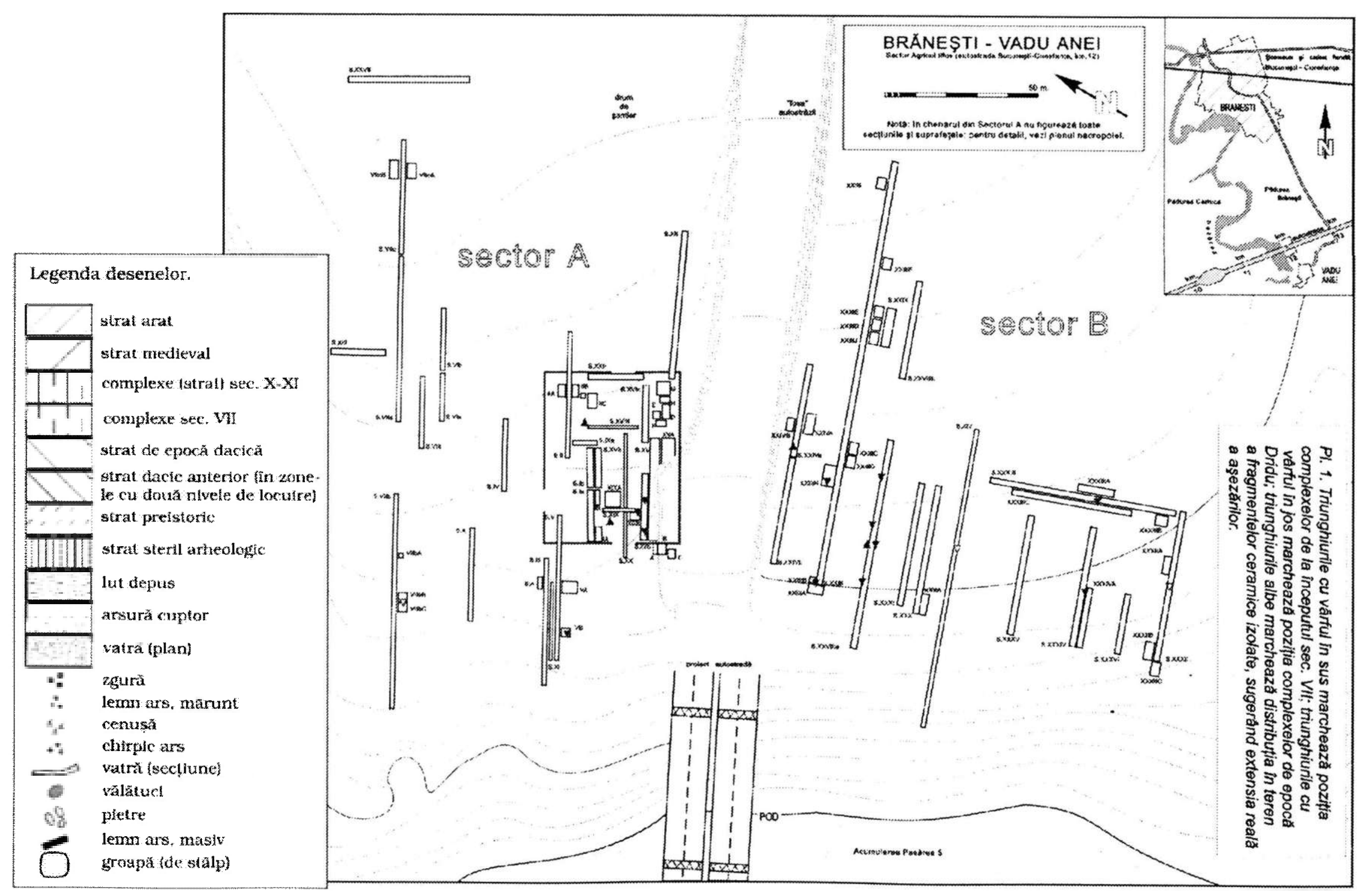

www.mnir.ro 


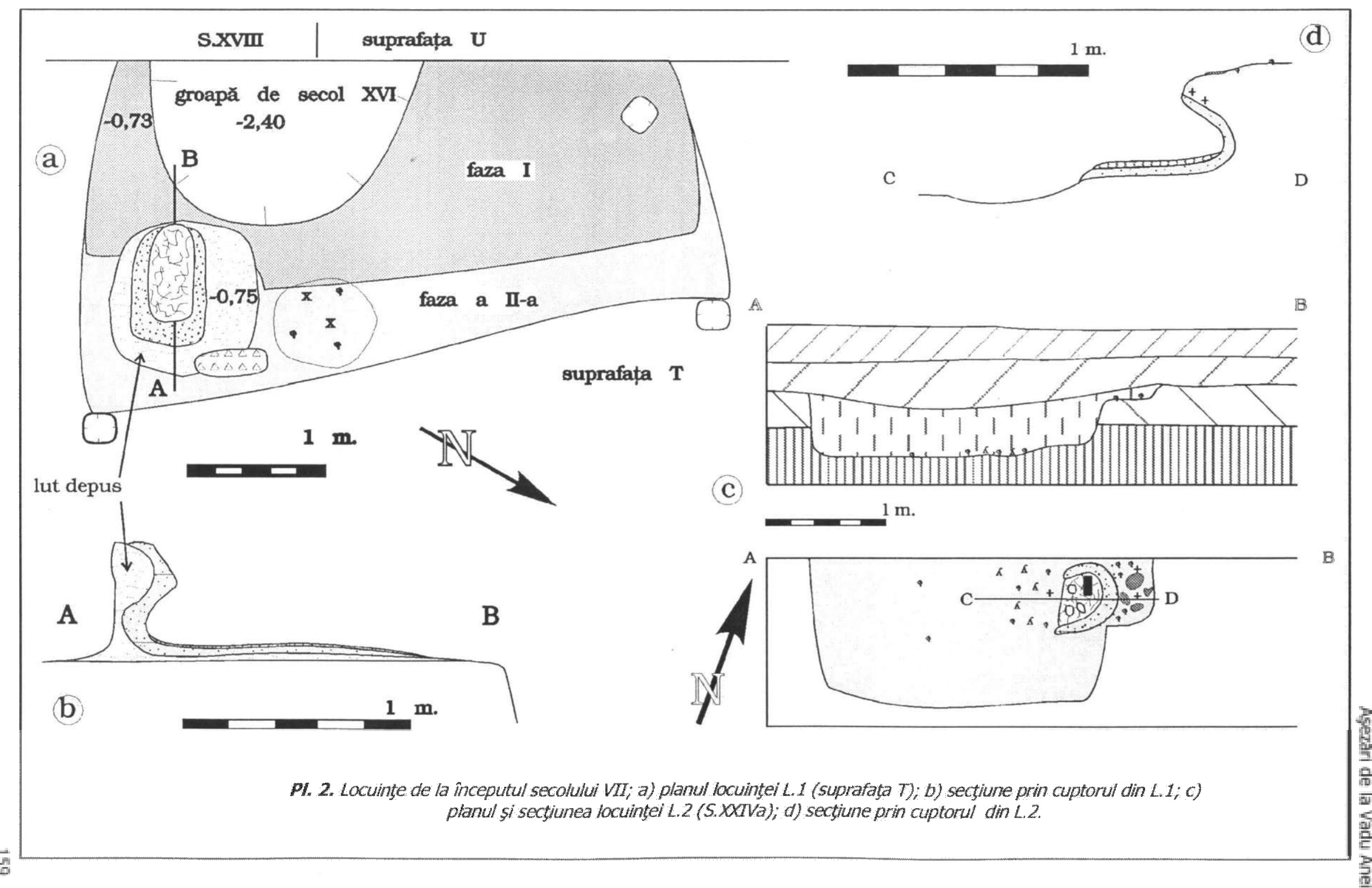

www.mnir.ro 
(a)
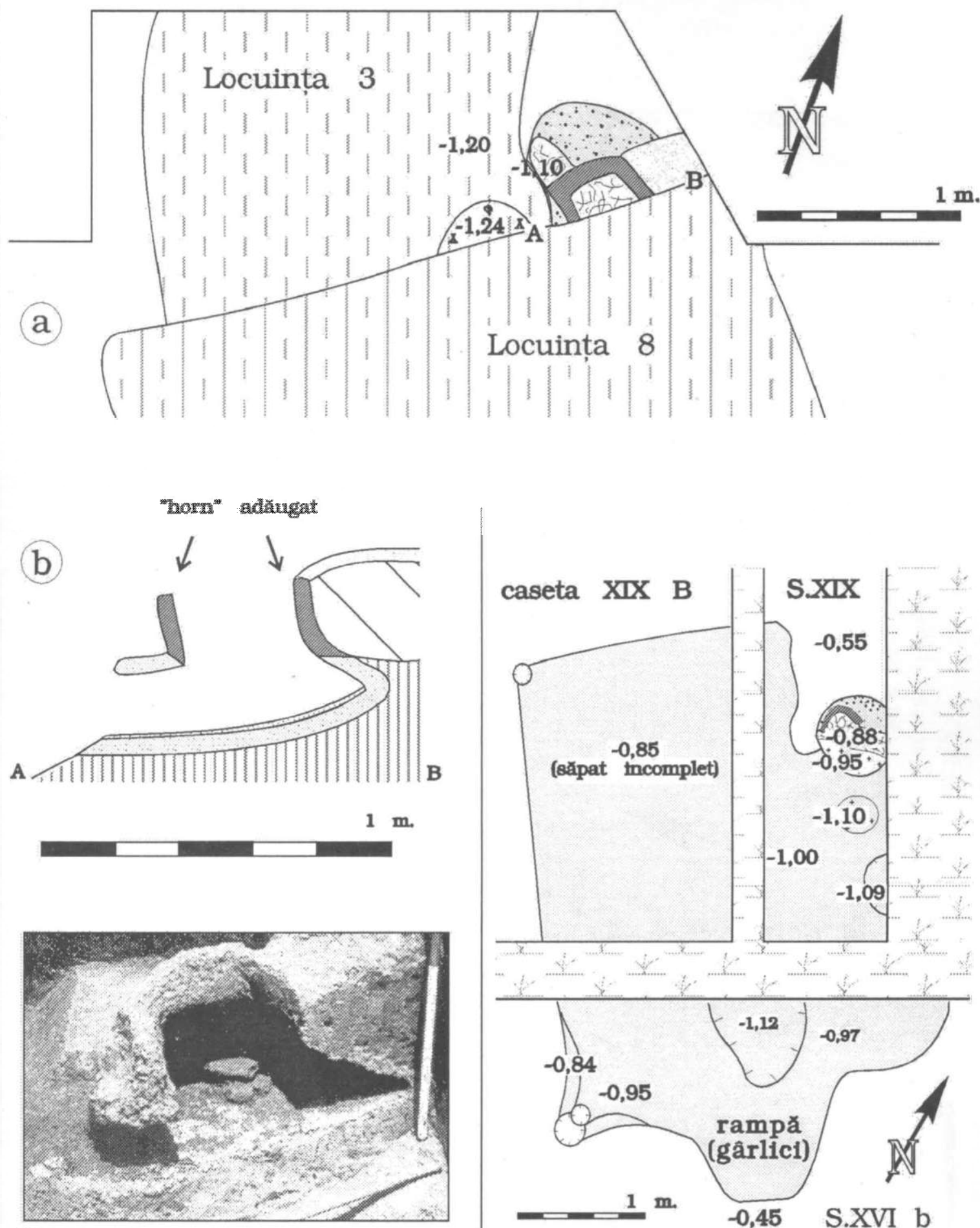

(c)

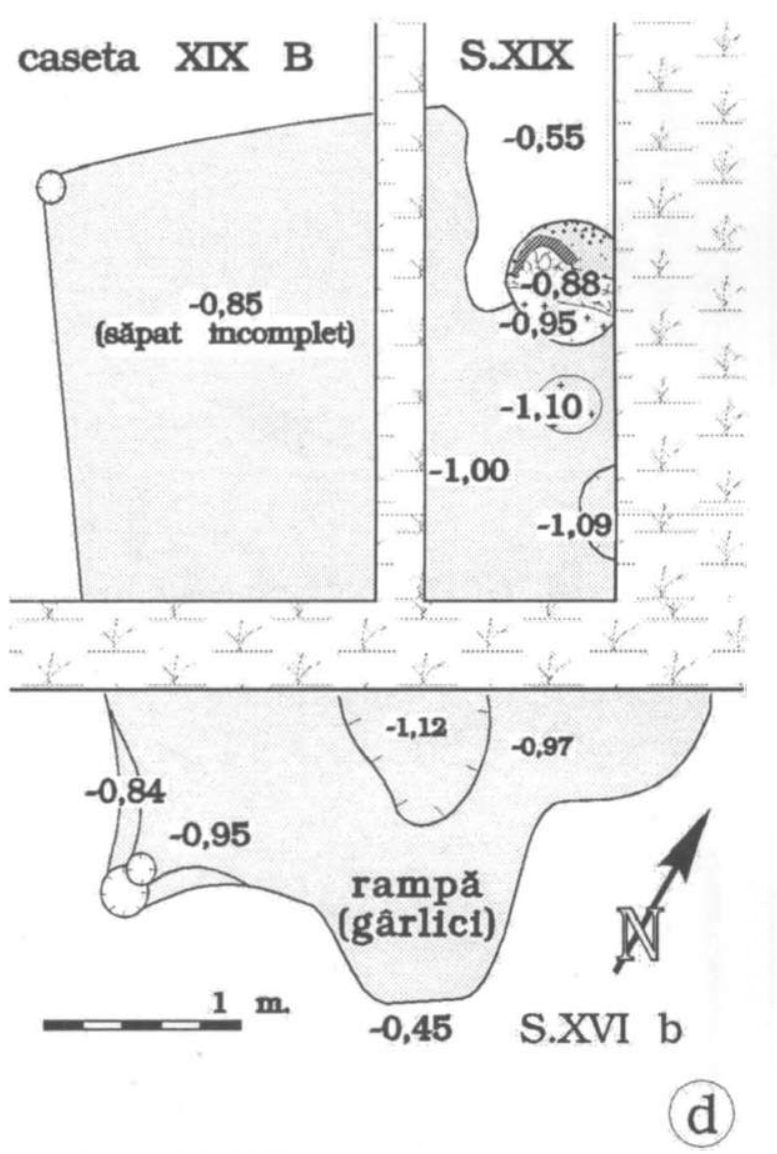

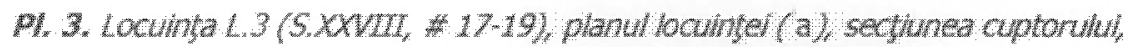
desen (b) si fotografie (c); locuinta 4 (intersectia S.XVIb si S.XDX) plan (d). 


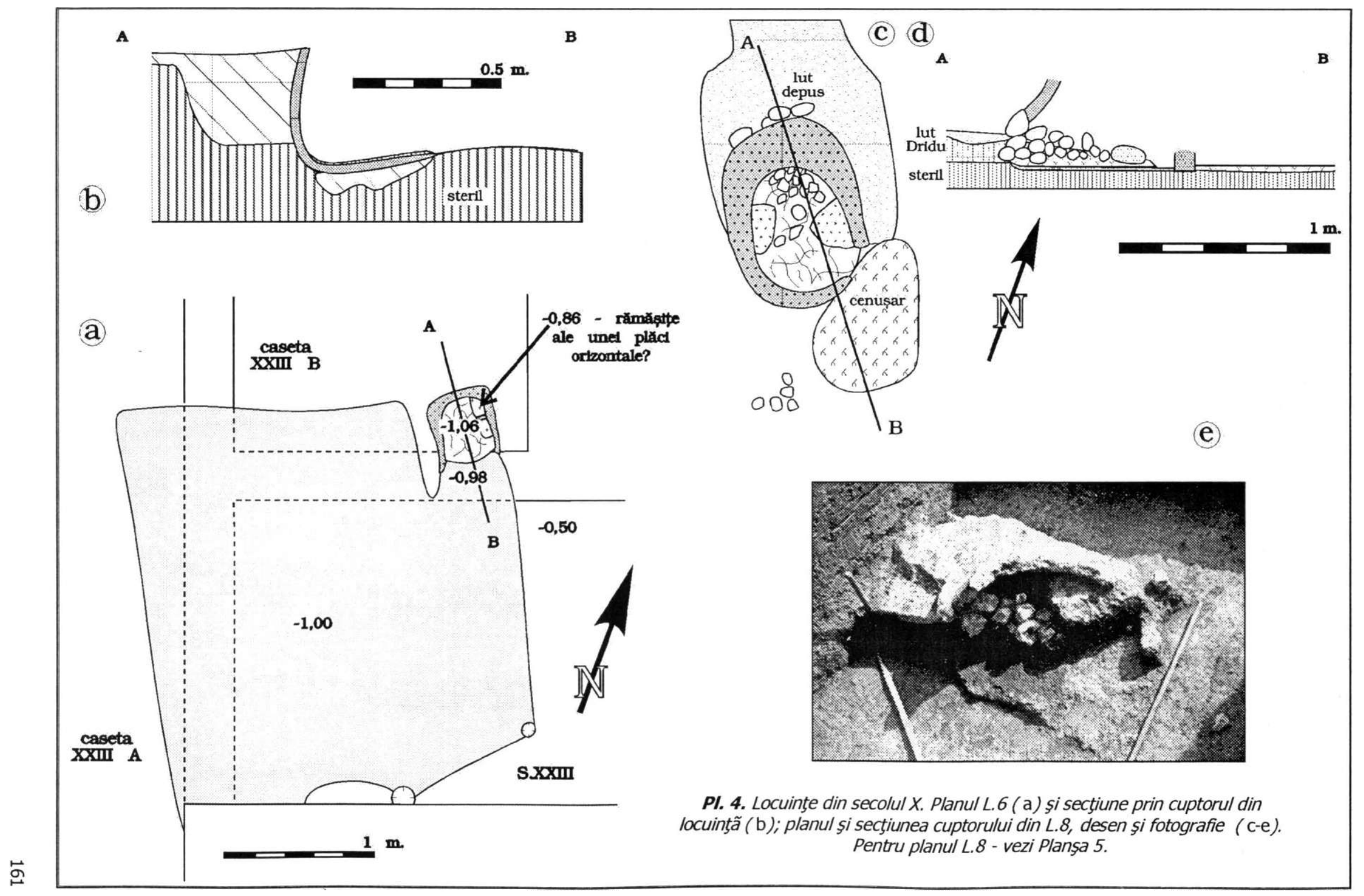

m.

a

PI. 4. Locuinte din secolul X. Planul L6 (a) şi sectiune prin cuptorul din cuinţã (b); planul şi secţiunea cuptorului din L.8, desen şi fotografie (c-e). Pentru planul L.8 - vezi Planşa 5. 

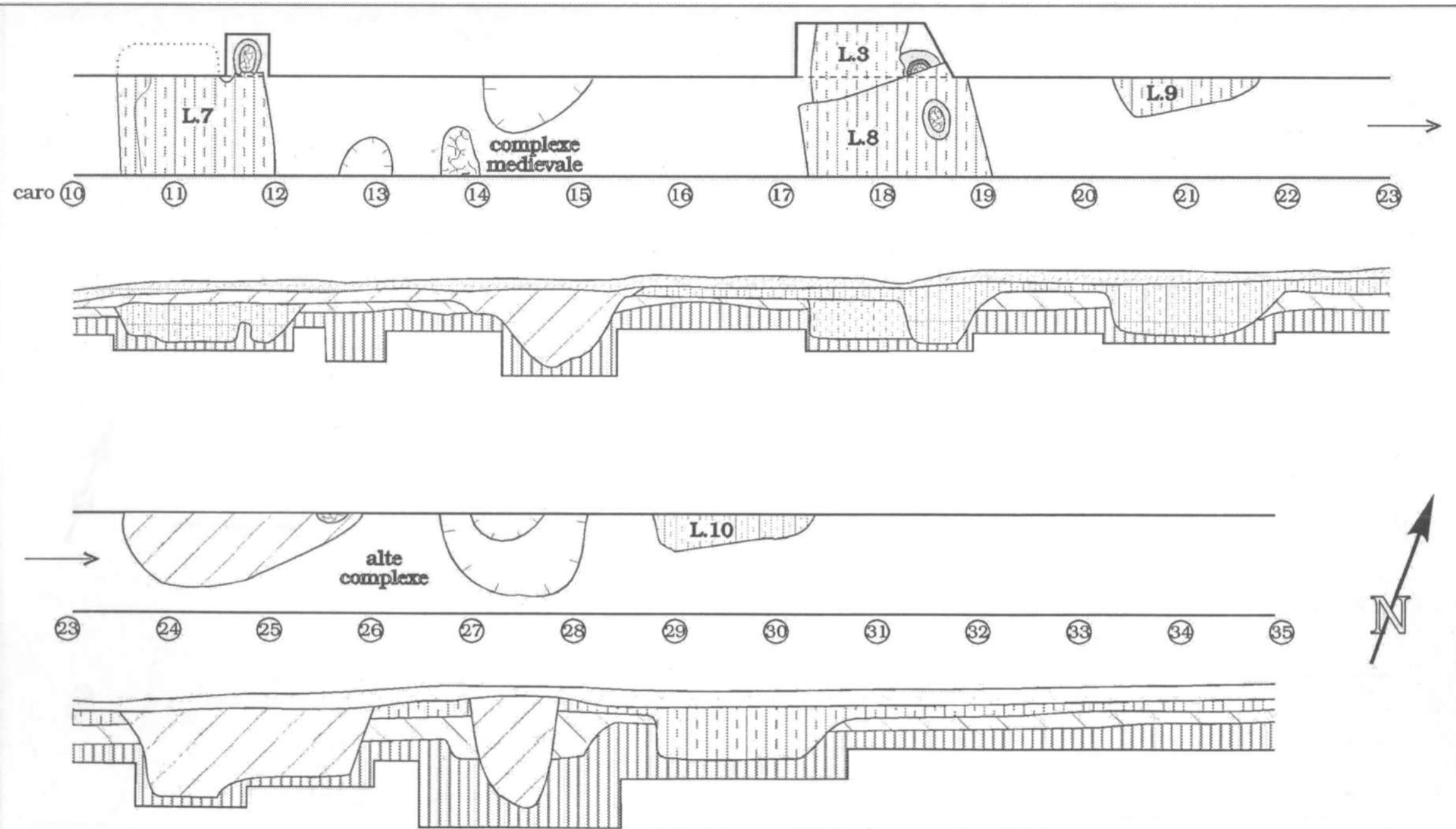

PI. 5. Secțiunea XXVIIIa, între metrii 20 - 70; locuinţele medievale $3 \mathrm{~m}$. sunt din mai multe epoci (sec. VII, sec. X-XI, sec. XVI) 


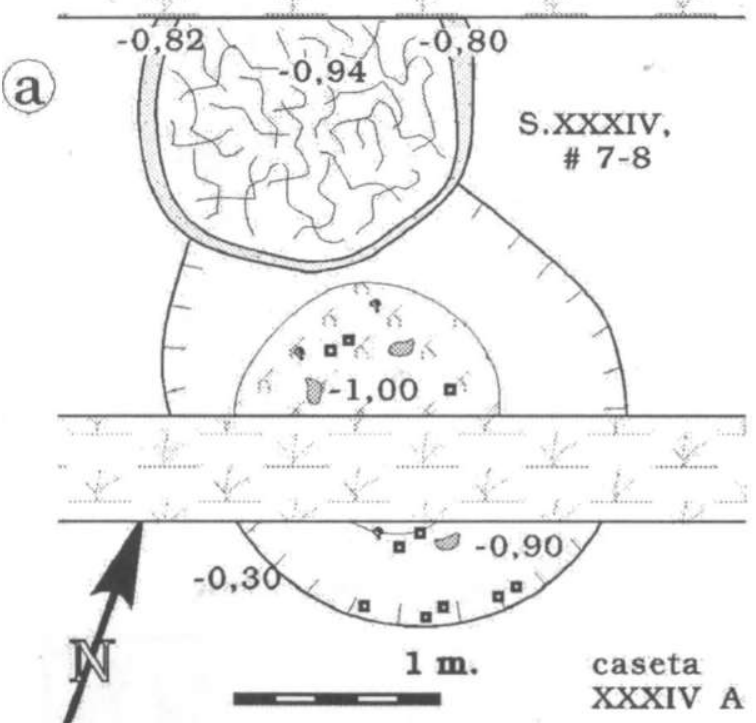

尔

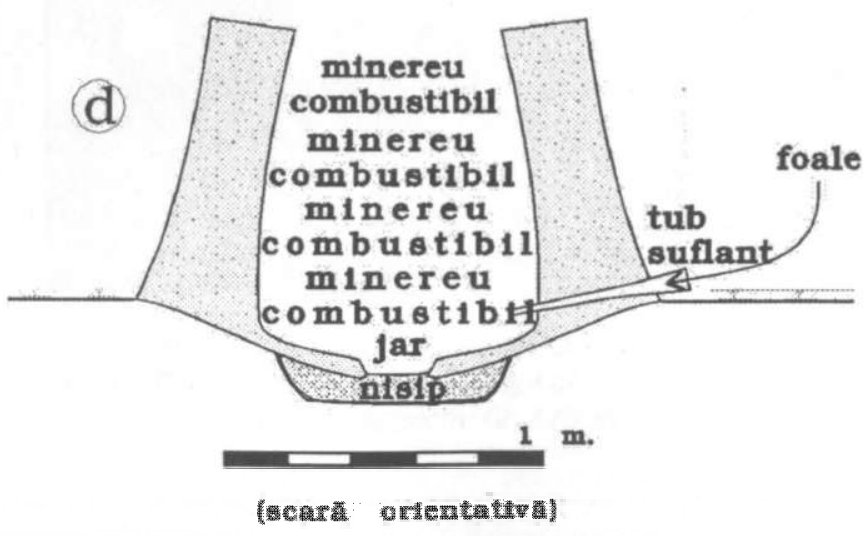

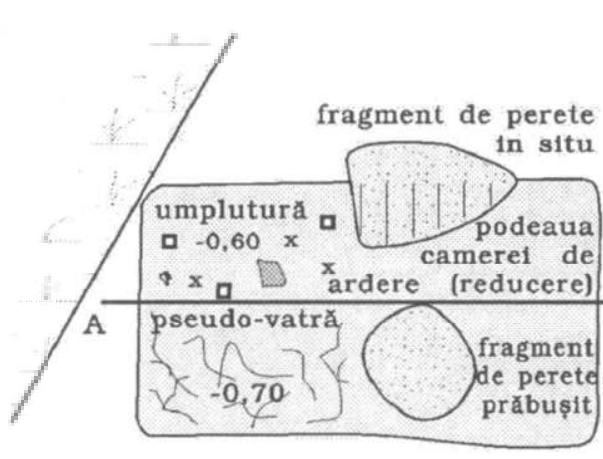

(b)

$1 \mathrm{~m}$.

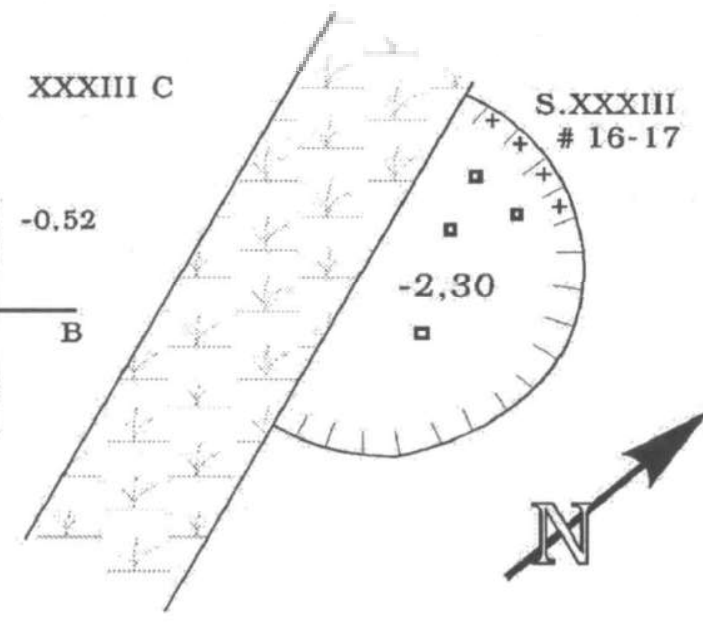

A

(c)

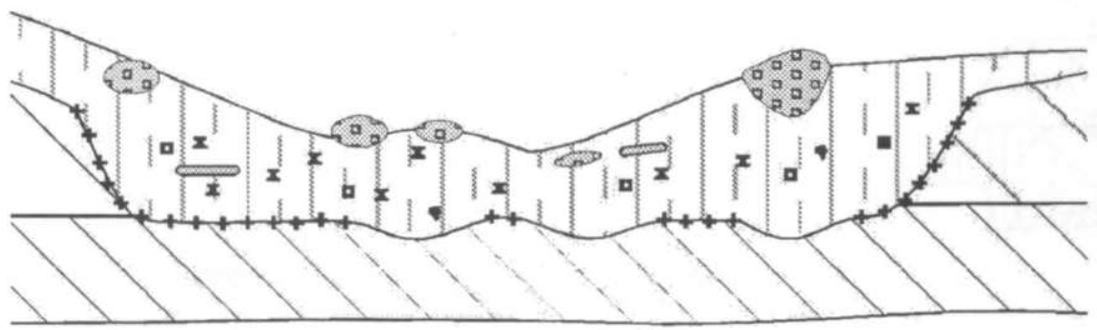

$1 \mathbf{m}$.

P1. 6. Complexe de utilhate metalurgica, cuptor de pasine (C.3) transformat in groapd de descuri metahurgice ( a), cuptor metalurgic (C.4) si groapa de deseuni pendinte (b); sectitune prin C. (c), reconstiburea C.4, sectiune (d). 


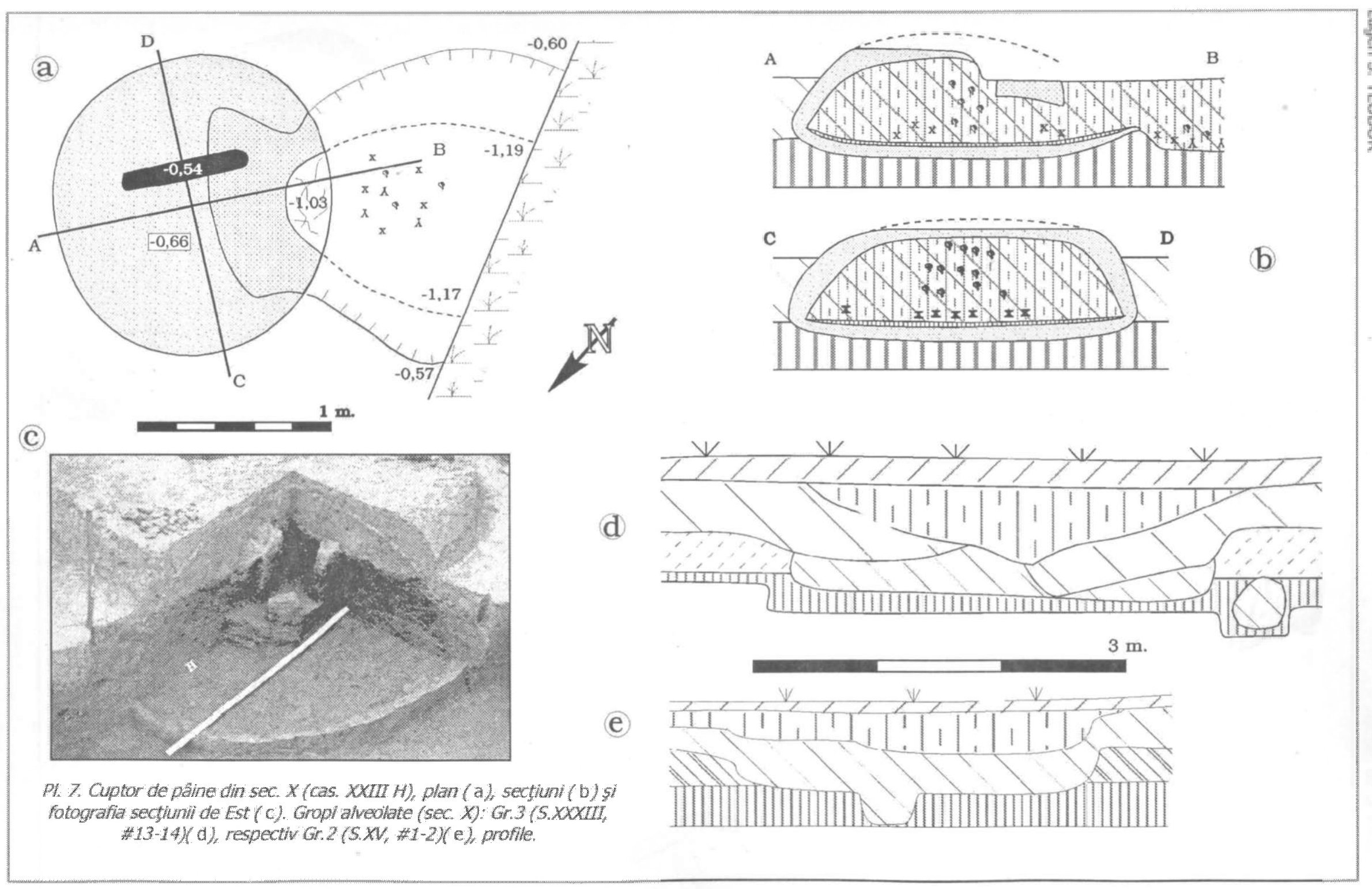



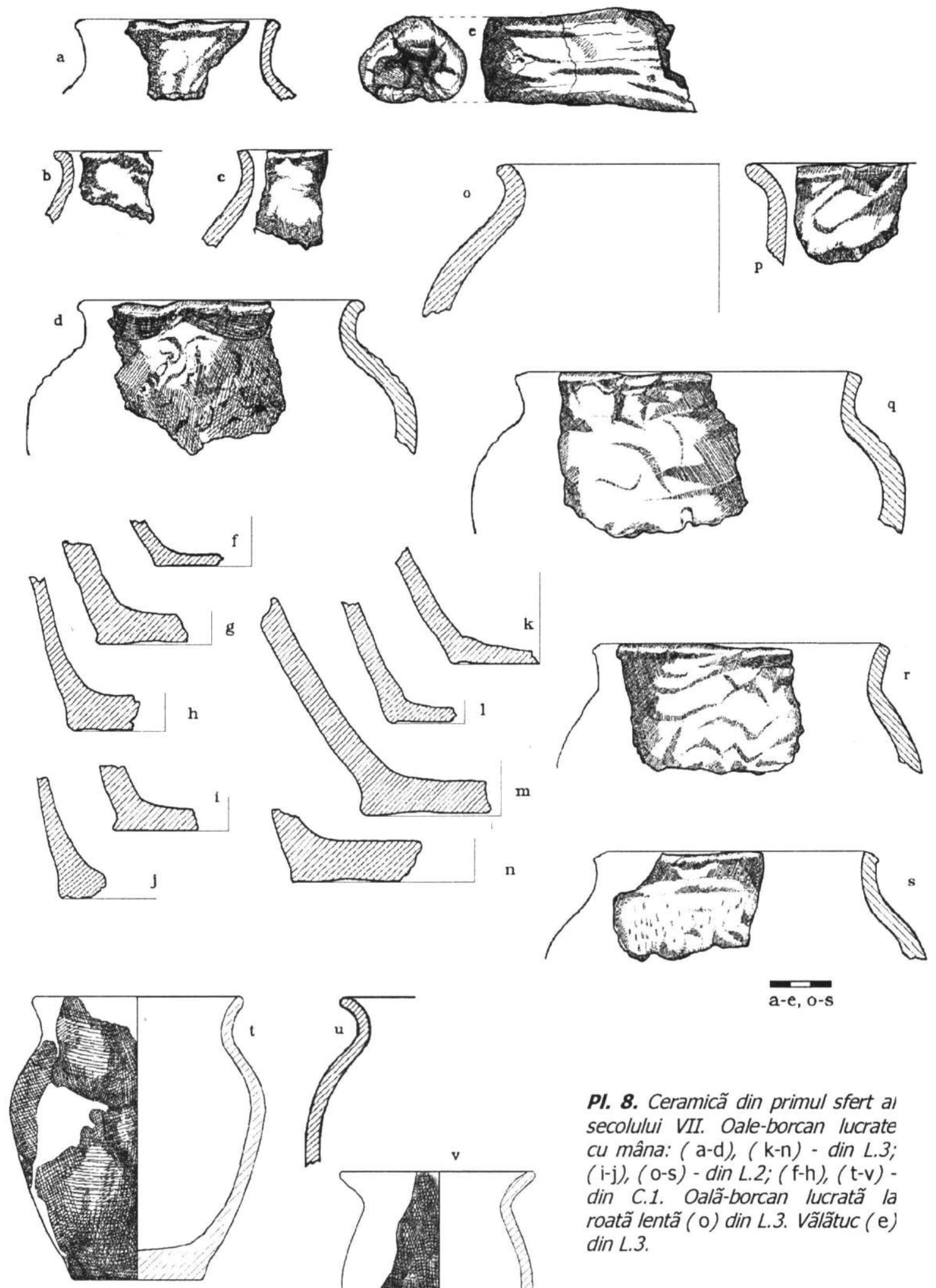

$\overline{f-n, t-y}$

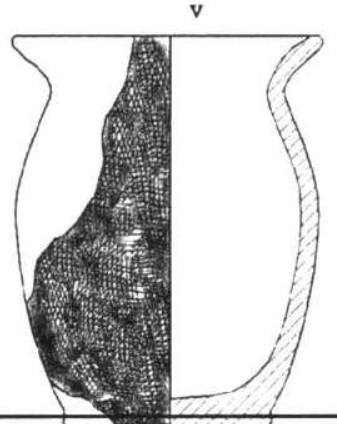

PI. 8. Ceramicã din primul sfert al secolului VII. Oale-borcan lucrate cu mâna: (a-d), (k-n) - din L.3; ( $\mathrm{i}-\mathrm{j}),(\mathrm{o}-\mathrm{s})-\operatorname{din} \mathrm{L} .2 ;(\mathrm{f}-\mathrm{h}),(\mathrm{t}-\mathrm{v})-$ din C.1. Oalã-borcan lucratã la roatã lentã ( o) din L.3. Vããatuc (e) $\operatorname{din}$ L.3. 


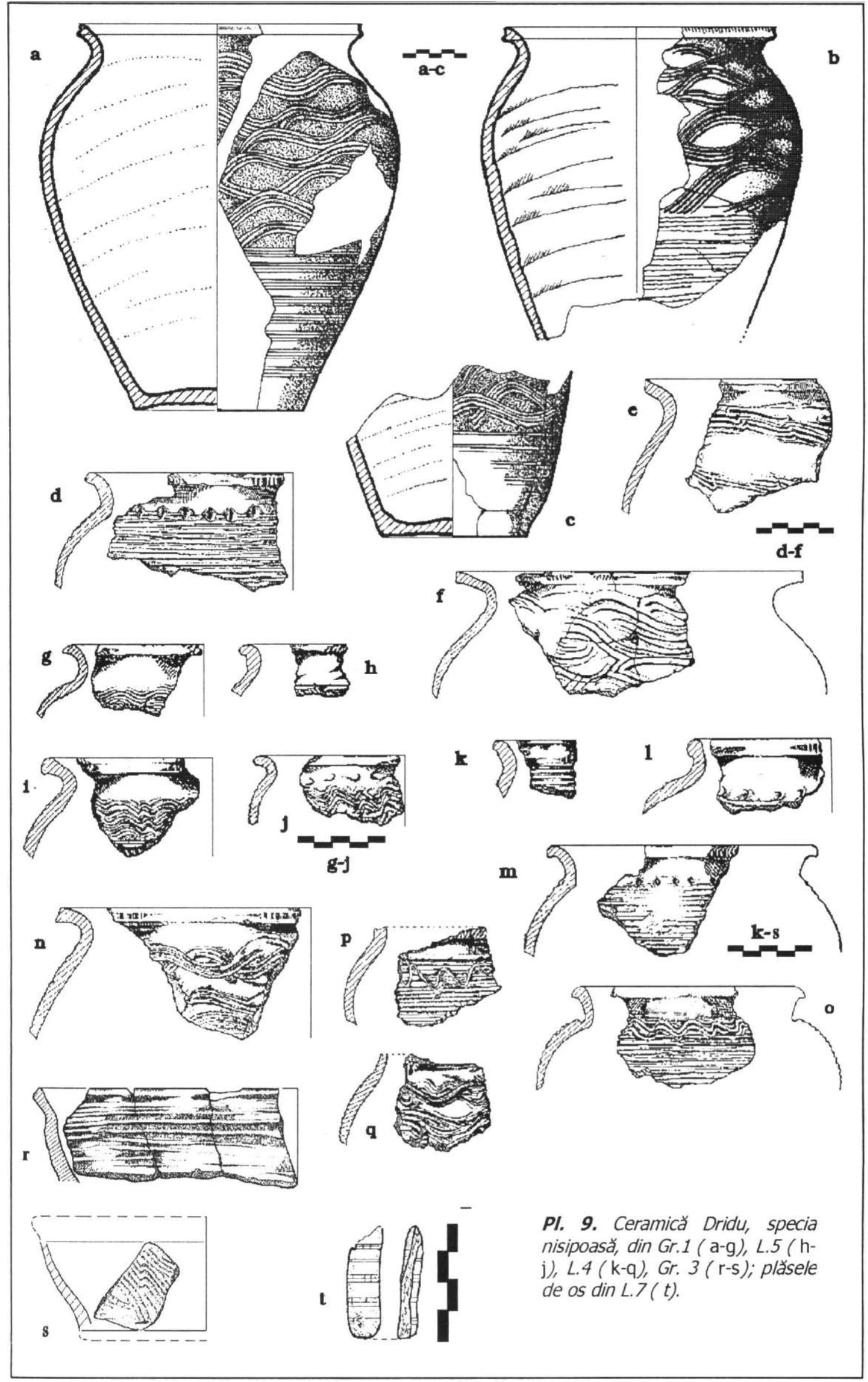



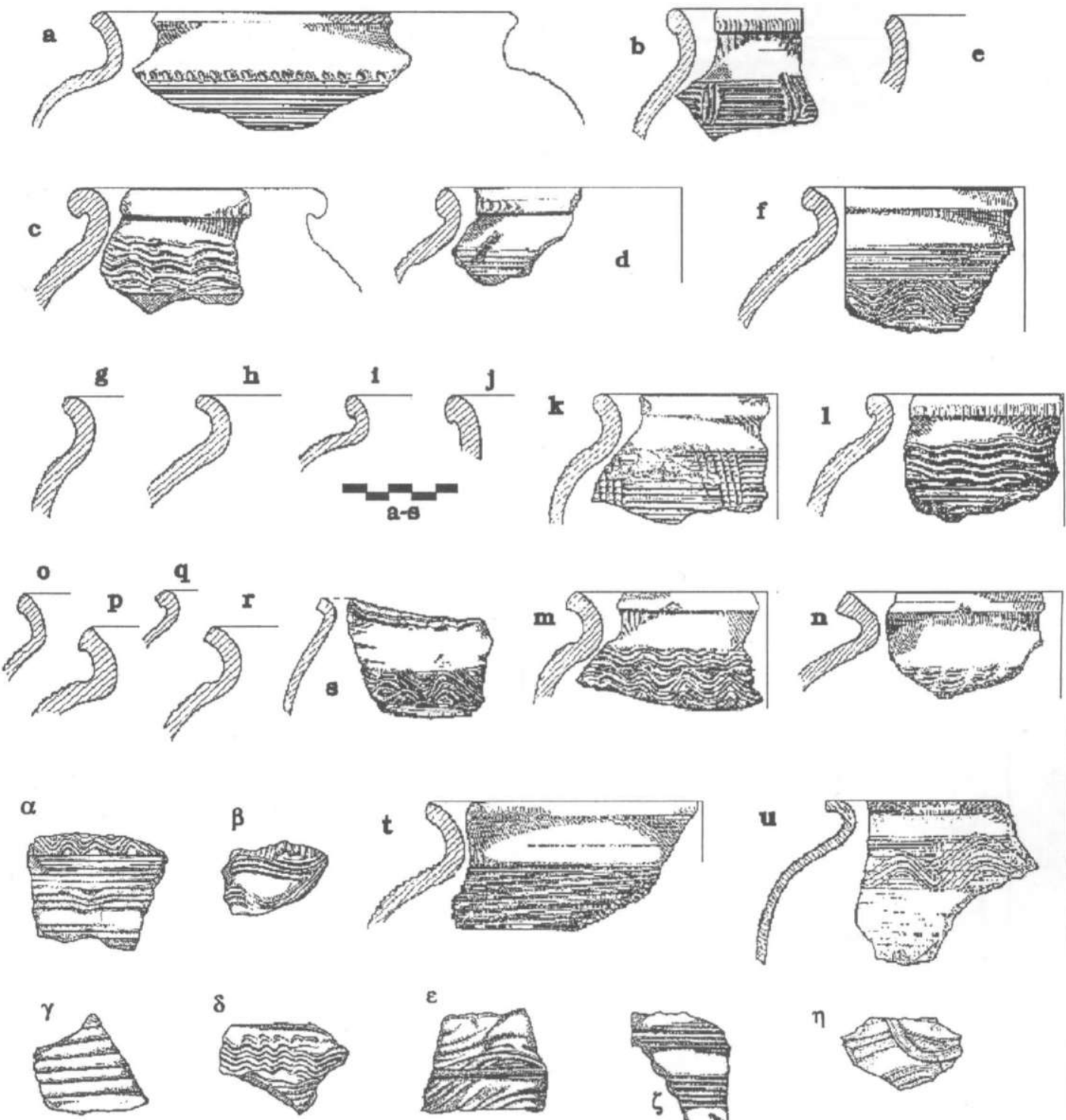

$\delta$
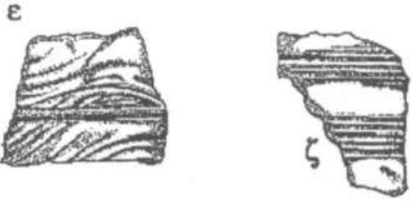

$\eta$
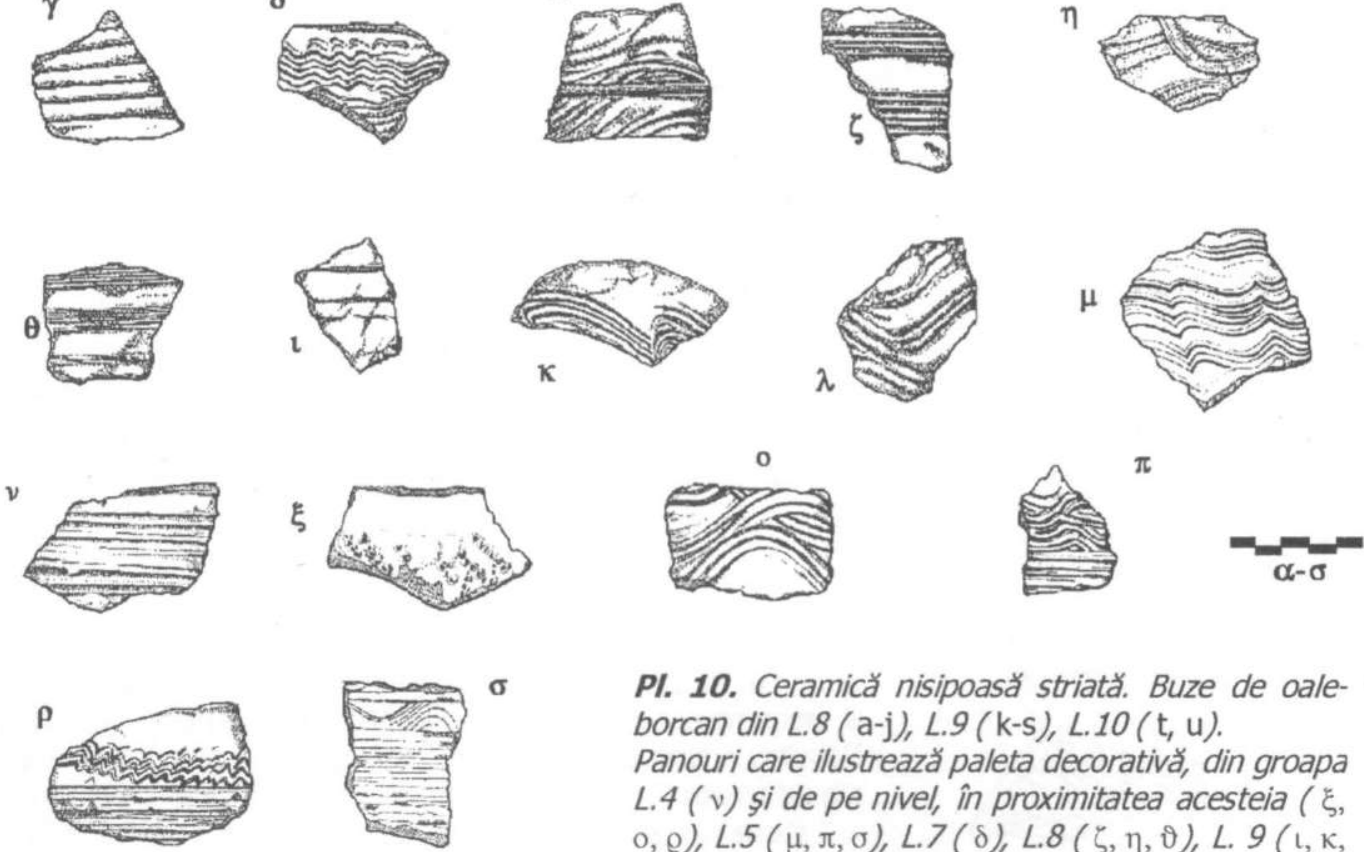

PI. 10. Ceramică nisipoasă striată. Buze de oaleborcan din L.8 (a-j), L.9 (k-S), L.10 (t, u). Panouri care ilustrează paleta decorativă, din groapa L.4 (v) şi de pe nivel, în proximitatea acesteia ( $\xi$, o, @), L.5 ( $\mu, \pi, \sigma), L .7(\delta), L .8(\zeta, \eta, \vartheta)$, L. $9(\mathrm{l}, \kappa$, $\lambda)$ L.10 ( $\alpha, \beta, \gamma, \varepsilon)$. 

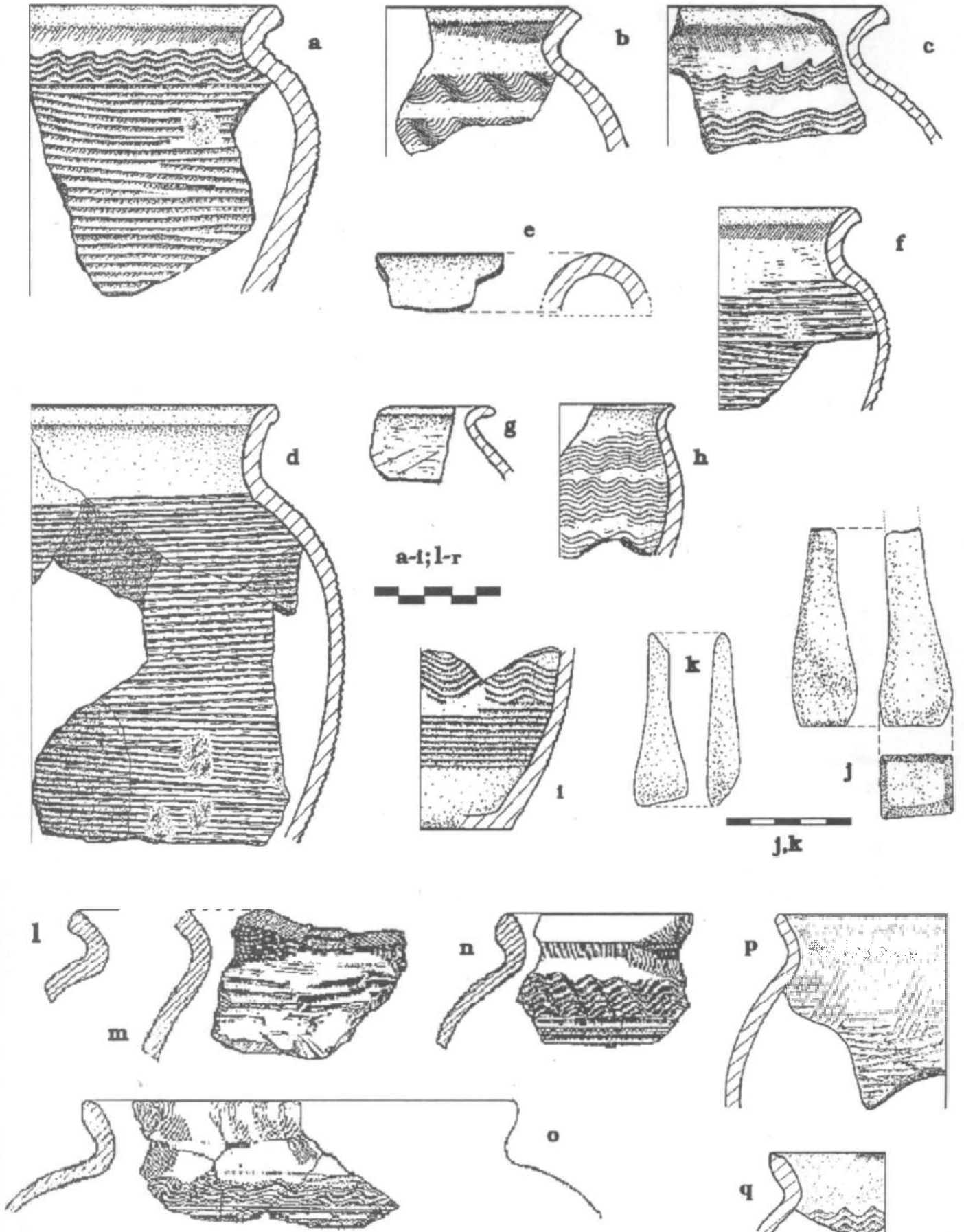

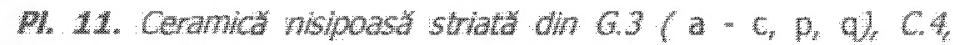
metalurgic $(\mathrm{d}, \mathrm{f})$, groapa de acces a C.3 $(\mathrm{g}-\mathrm{i})$, groapa de acces la C.2. cuptorut $L .6$ ( $n, 0)$, fragment izolat htr-o groapa medievala târzie $(\mathrm{m})$, fragment de tub suflant de la $\mathrm{c} .4(\mathrm{e})$. lustrutoare din graapa C.3 (1, k) r - borcan cu buza decorats (unicat din strat), 
a
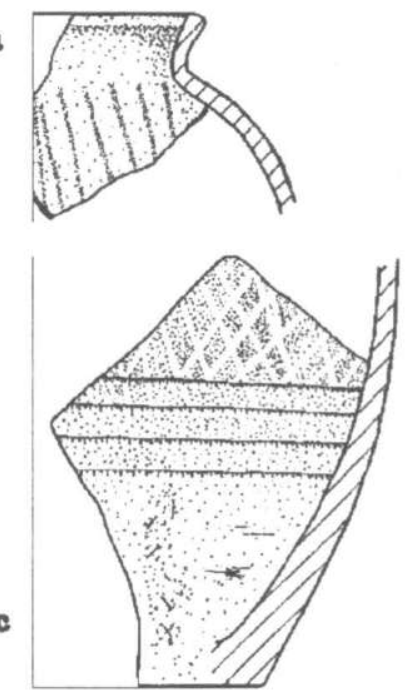
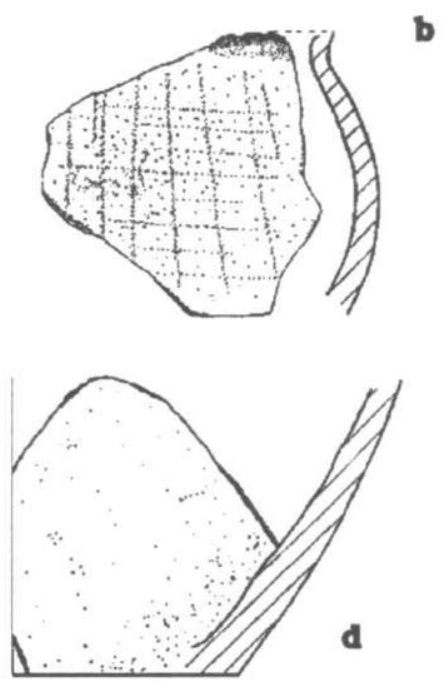

b

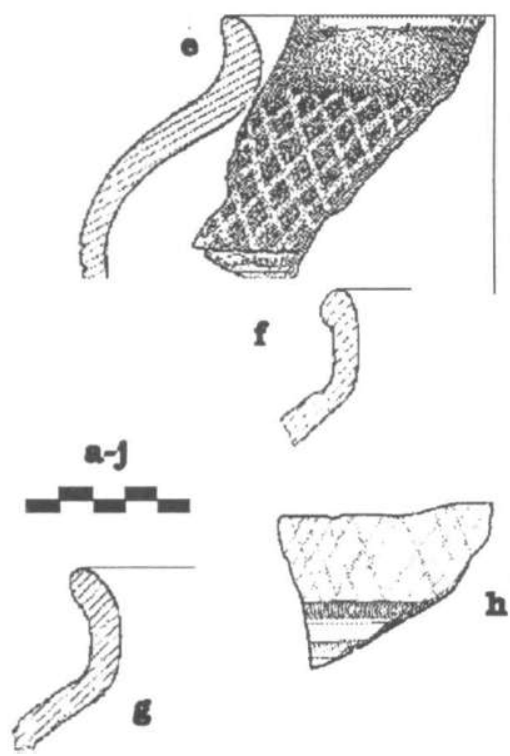

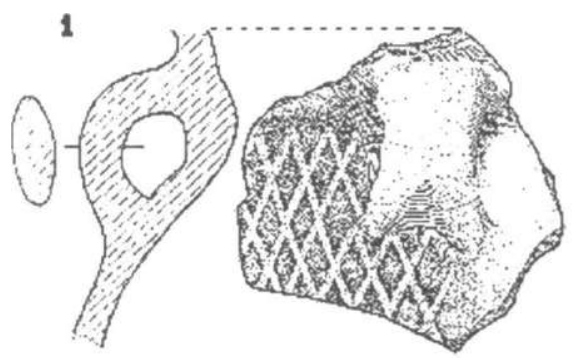
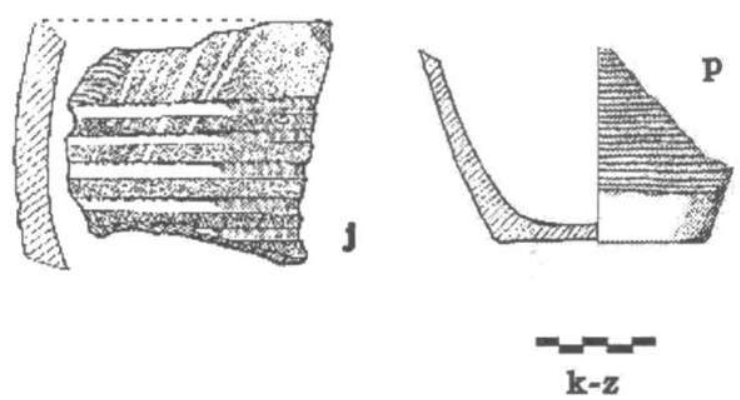

$\mathrm{k}$
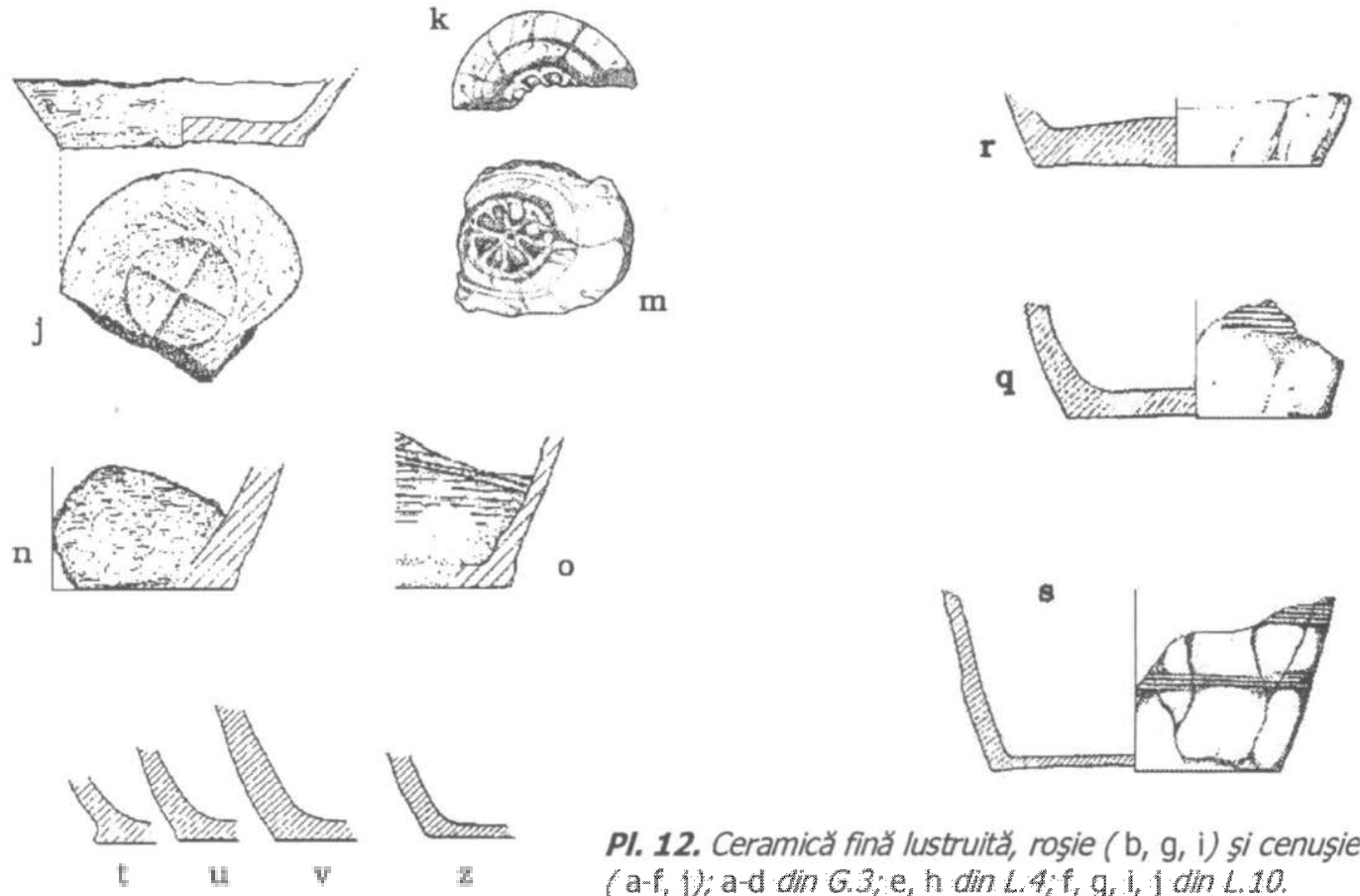

PI. 12. Ceramică fină lustruită, roşie ( $\mathrm{b}, \mathrm{g}, \mathrm{i})$ şi cenuşie ( $a-f, j)$; a-d din $G .3 ;$ e, h din L. $4, \mathrm{f}, \mathrm{g}, \mathrm{i}, \mathrm{j}$ din L. 10. Fundurl de oate-borcan nispoase: $1, m$ din $L .4 ; k, n, 0$

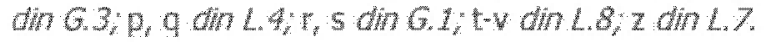




\begin{tabular}{|c|c|c|c|c|c|c|c|c|c|c|c|c|c|c|c|c|c|c|c|c|c|c|c|c|c|}
\hline identitate & LS & Fs & As & es & L & $\mathrm{Fi}$ & $\mathrm{Ai}$ & ei & $\begin{array}{l}\text { M/ } \\
\text { Is }\end{array}$ & $M / f$ & IG & UC & UB & ts & $\mathrm{ti}$ & P/Ii & $P / k$ & $\Pi$ & $f / a$ & $\mathrm{k} / \mathrm{a}$ & $\mathrm{I} / \mathrm{a}$ & Is/I & $\begin{array}{c}\mathrm{Mrf} \\
(* \mathrm{k})\end{array}$ & $\begin{array}{c}\mathrm{Gr} \\
\mathrm{s}\end{array}$ & Gri \\
\hline VIII/a, L.3 & & & & & & & & & & 32 & 35 & 110 & 63 & 142 & & & & & & & & & 9.7 & & \\
\hline VIII/b, L.3 & & & & & & & & & & & & 115 & & & & & & & & & & & & & \\
\hline VIII/C, L. 3 & & & & & & & & & & & & 98 & 63 & 129 & & & & & & & & & & & \\
\hline VIII/d, L.3 & 28 & -11 & 39 & 13 & & & & & 36 & 17 & 37 & 114 & 53 & 144 & & & & & 0.71 & & & & 13.9 & 68 & \\
\hline $\mathrm{VIII/f}, \mathrm{C} .1$ & & & & & & & & & & & & & & & 122 & & 6 & 0 & & & & & $* 9.7$ & 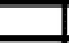 & 85 \\
\hline $\mathrm{VIII/a,C.I}$ & & & & & & & & & & & & & & & 112 & & 6 & 94 & & & & & *11.4 & & 161 \\
\hline $\mathrm{VIII} / \mathrm{h}, \mathrm{C.1}$ & & & & & & & & & & & & & & & 111 & & 17 & 0 & & & & & $* 9.4$ & & 213 \\
\hline VIII/i, L.2 & & & & & & & & & & & & & & & 117 & & 8 & 64 & & & & & $* 11.6$ & & 131 \\
\hline VIII/j, L.2 & & & & & & & & & & & & & & & 109 & & & & & & & & & & \\
\hline VIII/K, L.3 & & & & & & & & & & & & & & & 128 & & 13 & 0 & & & & & $* 9.1$ & & 119 \\
\hline VIII/L,L.3 & & & & & & & & & & & & & & & 114 & & 18 & 0 & & & & & $* 7.7$ & & 140 \\
\hline $\mathrm{VIII} / \mathrm{m}, \mathrm{L} .3$ & & & & & & & & & & & & & & & 130 & & 14 & 47 & & & & & $* 13.9$ & & 149 \\
\hline MII/O, L.3. & 29 & -11 & 51 & 11 & & & & & 29 & 11 & 48 & 110 & 59 & 135 & & & & & 0.71 & & & & 19.9 & 51 & \\
\hline VIII/p, L.2 & & & & & & & & & & & & 117 & 74 & 110 & & & & & & & & & & & \\
\hline $\mathrm{VIII} / \mathrm{q}, \mathrm{L} .2$ & 31 & -9 & 32 & 13 & & & & & 40 & 16 & 25 & 105 & 56 & 144 & & & & & 0.74 & & & & 14.9 & 62 & \\
\hline VIII/r, L.2 & 31 & -7 & 30 & 8 & & & & & 40 & 18 & 20 & 104 & 65 & 132 & & & & & 0.77 & & & & 13.8 & 60 & \\
\hline VIII/s, L.2 & & & & & & & & & & 20 & 50 & 97 & 64 & 140 & & & & & & & & & 12.7 & 65 & \\
\hline VIII/t, C.I & 29 & -6 & 36 & 11 & 22 & -16 & 38 & 6 & 55 & 31 & 41 & 110 & 63 & 130 & 125 & 15 & 21 & 0 & 0.80 & 0.52 & 1.15 & 0.39 & 10.2 & 70 & 230 \\
\hline VIII/U, C.I & & & 45 & 11 & & & & & 34 & & 42 & 129 & 65 & 134 & & & & & & & & & & & \\
\hline VIII/v, C.1 & 30 & 0 & 40 & 4 & 28 & -16 & 48 & 6 & 41 & 22 & 32 & 131 & 73 & 113 & 118 & 8.4 & 9 & 77 & 1.00 & 0.68 & 1.29 & 0.43 & 10.7 & 36 & 134 \\
\hline
\end{tabular}

MEDII

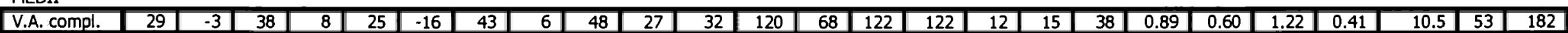

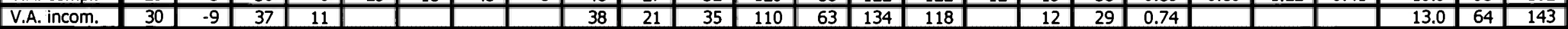

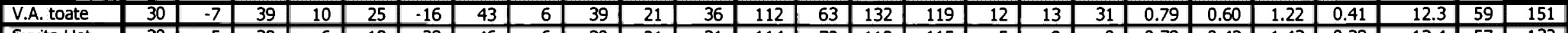

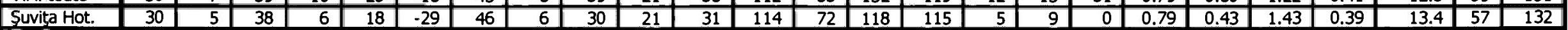

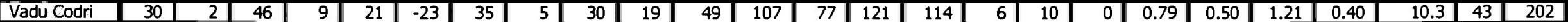

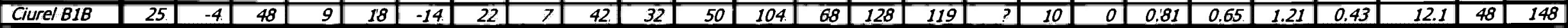

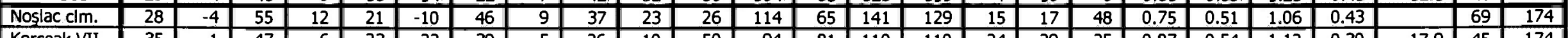

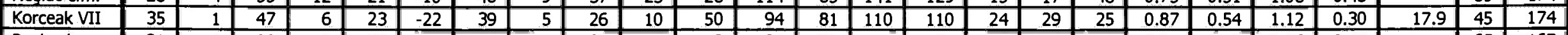

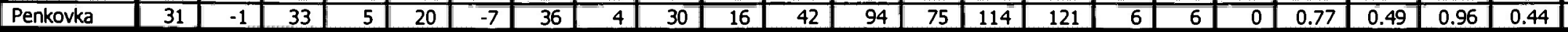

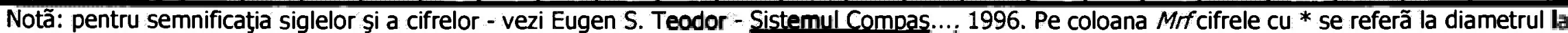
bazã, celelalte reprezintã diametre la gurã.

prescurtãri: V.A. = Vadu Anei; compl. = vasele întregite; incom. = toate vasele fragmentare; toate = toate vasele (întregi şi fragmentare); Şuviţa Hot = Cãscioarele - Şuviţa Hotarului; Vadu Codrii = Piatra Olt - Vadu Codrii; Noşlac clm. = numai ceramica lucratã cu mâna; cu italice - ceramicã lucratã pe roata lentã; pentru bibliografie şi ilustraţie - vezi textul şi notele; 